\title{
Report on Technical
}

Feasibility of Underground

Pumped Hydroelectric

Storage in a Marble Quarry

Site in the Northeast United

States

Chas. T. Main, Inc.

March 1982

Prepared for Pacific Northwest Laboratory

under Agreement B-B5211-A-0

for the U.S. Department of Energy

under Contract DE-AC06-76RLO 1830

Pacific Northwest Laboratory

Operated for the U.S. Department of Energy

by Battelle Memorial Institute 


\title{
DISCLAIMER
}

This report was prepared as an account of work sponsored by an agency of the United States Government. Neither the United States Government nor any agency thereof, nor any of their employees, makes any warranty, express or implied, or assumes any legal liability or responsibility for the accuracy, completeness, or usefulness of any information, apparatus, product, or process disclosed, or represents that its use would not infringe privately owned rights. Reference herein to any specific commercial product, process, or service by trade name, trademark, manufacturer, or otherwise, does not necessarily constitute or imply its endorsement, recommendation, or favoring by the United States Government or any agency thereof. The views and opinions of authors expressed herein do not necessarily state or reflect those of the United States Government or any agency thereof.

\author{
PACIFIC NORTHWEST LABORATORY \\ operated by \\ BATTELLE \\ for the \\ UNITED STATES DEPARTMENT OF ENERGY \\ under Contract DE-AC06-76RLO 1830
}

\begin{tabular}{|c|c|}
\hline \multirow{2}{*}{\multicolumn{2}{|c|}{ Printed in the United States of America }} \\
\hline \multirow{2}{*}{\multicolumn{2}{|c|}{$\begin{array}{c}\text { Available from } \\
\text { National Technical Information Service }\end{array}$}} \\
\hline & \\
\hline \multicolumn{2}{|c|}{$\begin{array}{l}\text { National Technical Information Service } \\
\text { United States Department of Commerce }\end{array}$} \\
\hline \multicolumn{2}{|c|}{5285 Port Royal Road } \\
\hline \multicolumn{2}{|c|}{ Springfield, Virginia 22151} \\
\hline \multirow{2}{*}{\multicolumn{2}{|c|}{$\begin{array}{l}\text { NTIS Price Codes } \\
\text { Microfiche A01 }\end{array}$}} \\
\hline & \\
\hline \multicolumn{2}{|c|}{ Printed Copy } \\
\hline & Price \\
\hline Pages & Codes \\
\hline $001-025$ & $\mathrm{~A} 02$ \\
\hline $026-050$ & $\mathrm{~A} 03$ \\
\hline 051-075 & $\mathrm{A} 04$ \\
\hline $076-100$ & A05 \\
\hline $101-125$ & A06 \\
\hline $126-150$ & $\mathrm{~A} 07$ \\
\hline $151-175$ & $\mathrm{~A} 08$ \\
\hline $176-200$ & A09 \\
\hline $201-225$ & A010 \\
\hline $226-250$ & A011 \\
\hline $251-275$ & $\mathrm{~A} 012$ \\
\hline $276-300$ & $\mathrm{~A} 013$ \\
\hline
\end{tabular}


REPORT ON TECHNICAL FEASIBILITY OF UNDERGROUND PUMPED HYDROELECTRIC STORAGE IN A MARBLE QUARRY SITE IN THE NORTHEAST UNITED STATES

Chas. T. Main, Inc.

March 1982

Prepared for the U.S. Department of Energy under Contract DE-AC06-76RLO 1830

Pacific Northwest Laboratory Richland, Washington 99352 


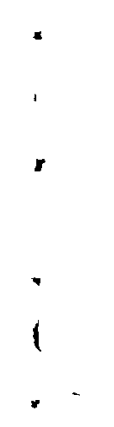


FOREWORD

Underground pumped hydroelectric storage (UPH) is a technique for supplying electric power to meet peak load requirements of electric utility systems. Using low-cost power from base load plants during off-peak periods, pumps raise water to a surface pond from an underground reservoir, a mined out space in competent hard rock. During subsequent peak load periods, the surface pond water drops to the lower reservoir through turbines to generate peak power. This relatively new adaption of pumped storage technology offers significant potential for reducing costs and improving efficiency of electric peak power generation, as well as reducing utility petroleum fuel consumption.

Based on these potential benefits, the U.S. Department of Energy's (DOE) Electric Energy Systems Division sponsors programs and projects to accelerate commercialization of UPHS technology. The Pacific Northwest Laboratory (PNL) is the designated lead laboratory role for the UPH activities, but many other laboratories and contractors have been involved. DOE and the Electric Power Research Institute (EPRI) recently completed a major design study on UPHS, published as EPRI EM-1589, and there are major pump turbine development programs underway throughout industry for the high head application of the concept.

An important element of DOE's effort is to promote commercialization of UPH technology through the transfer of research results and experience to interested utilities. Toward this end Chas. T. Main of Bóston, Massachusetts, a previous contributor to UPH development, was selected to perform a preliminary study aimed at examining UPH feasibility on the Northeast Power Pool. Conducted for the Central Vermont Public Service Corporation, a member utility actively planning a UPH facility in the U.S., the study resulted in this report. 
The marble quarries at West Rutland have been mined for architectural and monumental stone since 1807. With the market for such products diminished in recent years, production essentially ceased in 1972. Consequently the present owners are attempting to develop the site for other uses, among them oll storage and as a hydro-electric pumped storage site.

The unique feature of using the marble quarries as a site for a hydro-electric pumped storage plant is that a substantial amount of the excavated material from construction of the project has some commerclal value in the production of ground products as fillers for paints, toothpaste and other 1tems. Sale of the excavated material would therefore affect the total capital cost of the project and make it a more attractive investment.

Although construction of a conventional pumped storage scheme was originally investigated, using the existing quarries for the lower reservolr, economy of scale and recent technological advancement in the development of very high head pump-turbines suggest that an underground pumped storage facility could prove feasible especially if some of the excavated material from construction could be sold.

As a result, this report has been directed to examining the technical and economic aspects of construction of a very high head, underground hydro-electric pumped storage project at a prefeasibility level. The capacity of the project was selected to be consistent with the conventional pumped hydro-electric plant sizes currently under study by the New England System. Since this would be the third pumped storage plant on the system, this plant would be tentatively placed below the other two on the wider part of the load curve, depending on efficiency, and would operate for longer perlods of time. For the purpose of this study, a capacity of $1200 \mathrm{MW}$ and 12 hours of continuous operation at rated capacity were chosen. 
$\underline{\text { Geology }}$

In an underground pumped storage facility, the complexities of stratigraphy and structure play an important role. Although more than a century has been spent on investigation of the general area by numerous geologists, individual interpretations of both structural deformation and stratigraphic sequences vary widely. The source study included a number of publications of the Vermont Geological Survey and communication with a number of geologists who have worked in the area but the most significant results to date appear to be the cores from the logs of one boring made at the site to a depth of 2422 feet.

It appears that some marble of varying quality exists to an elevation just below about 1000 foot depth but 1 t is questionable whether any of 1 t has any value. Below that to the bottom of the hole, the rock is mostly schistose interspersed with various other minerals. Barring any unforseen circumstances however, it is judged that this material is strong enough to support the excavations contemplated for the project.

With the total amount of storage flxed at 12 hours or 14,400 MWh the head has direct influence on the amount of excavation required for the reservolr. As a consequence, the highest head pump-turbine expected to be avallable in the mid 1990 's was used in evaluation of the project. At present this appears to be approximately 4000 feet.

To accommodate the storage, the lower reservoir was designed as 25 paralle1 tunnels, oriented in an east-west direction 50 feet in diameter connected at the ends by transverse tunnels. Live storage capacity is about 6.7 million cubic yards or 4150 acre-feet. A vertical shaft on the west transverse tunnel is vented to the surface near route $\#_{4}$.

Two configurations were studied for the upper reservolr, one at the top of Clark H111 to the southwest of the site and the second, enlargement and connection of the existing quarries. Since the excavated material at the lower reservoir depth appears to have little or no commercial value and yet must be disposed of in some way, Scheme 1 utilizes all of the excavated materlal in construction of an impounding dike at the top of the hill. 
The second, by enlarging and extending the quarries into one reservoir, recognizes the value of some of the excavated material and utilizes the remainder in construction of a dike surrounding it. In this case, excavation from the lower reservoir must be spoiled in the swampy area adjacent to the Castleton River.

The powerplant complex, consisting of the powerplant, transformer gallery, and the draft tube gate gallery, is located at the lower reservoir level. It is connected to the surface by several service shafts and the intake shaft, manifold, and penstocks carrying water to and from the upper reservoir. The pump turbines are connected to the lower reservolr by means of the draft tube tunnels and the draft tube collector tunnel which intersects the east transverse tunnel.

The powerplant cavern contains the four vertical shaft two stage reversible pump turbines, each capable of producing 415,000 H.P. at 720 R.P.M. Each is directly connected to a vertical shaft generator-motor capable of producing 300 MW at .9 power factor with a maximum of $60^{\circ} \mathrm{C}$ rise.

Electrical and mechanical equipment necessary to the operation of each unit is arranged in galleries on the upstream side of the units. Those appurtenances common to the operation of the total plant are arranged on floors under the erection bay.

An erection and service bay is provided at the end of the unit blocks for erection and service of the rotor and major turbine parts. A 250 ton bridge crane for handling major equipment and a 25 ton bridge crane for handling equipment of lesser weight are provided in the powerplant cavern.

The transformer gallery is located directly above the powerplant cavern and connected to it by a series of adits and shafts to contain the low voltage bus connection to the transformers. Because of welght limitations in the heavy hoist shaft, single phase transformers were selected for this project. Output from two units is fed to one bank of three single phase transformers. 
Two banks of single phase transformers are arranged in the transformer gallery, each separated by concrete firewalls with a common transfer way on the downstream side. Isolation walls adjacent to the transformer are designed to contain transformer fires which could occur. $\mathrm{CO}_{2}$ fire protection is provided for each transformer and an 1solated exhaust system provided as well.

An adit is provided from this level to the draft tube gate gallery. The gate gallery is arranged so that each unit may be isolated, unwatered, and such repairs as necessary accomplished without shutting down the entire plant. Draft tube gates are provided at each unit discharge with an overhead crane to lift and deposit each gate. A bypass to balance head on the gates is provided at each draft tube.

Cost of the $1200 \mathrm{MW}$ underground pumped storage hydro electric project at this site even with the proposed savings from marketable material amounts to between $\$ 581$ and $\$ 595$ per kilowatt of installed capacity on a January 1982 pricing level. System studies performed by the planning group of the New England Power System indicate that the system could economically justify up to about $\$ 442$ per kllowatt on an energy basis with no credit for capacity.

To accommodate the plant with the least expensive pumping energy, a coal and nuclear generation $\mathrm{mix}$ of approximately $65 \%$ would have to be available before the project becomes feasible. It is not expected that this condition can be met before the year 2000 or beyond.

It is therefore concluded that the West Rutland underground pumped storage facility is uneconomic at this time. Several variables however could have marked influence on future planning and should be examined on a periodic basis. 
Section

1. INTRODUCTION 1-1

2. GEOLOGY 2-1

3. PROJECT DESCRIPTION 3-1

3.1 Lowe r Reservoir 3-1

3.2 Lower Reservo1r Design 3-2

3.3 Upper Reservior 3-3

3.4 Intake 3-5

3.5 Powerplant Complex 3-5

3.6 Powerplant 3-6

3.6.1 Machine Hall 3-6

3.6.2 Electrical Gallery 3-7

3.6.3 Turbine Gallery $3-7$

3.6.4 Spherical Valve Gallery 3-7

3.6.5 Erection and Service Bay 3-8

3.7 Transformer Gallery 3-8

3.7.1 Generator-Motor Leads 3-9

3.7.2 High Voltage Cables 3-10

3.8 Draft Tube Gate Chamber 3-10

3.9 Permanent Shafts 3-10

3.9.1 Requirements 3-10

3.9.2 Water Intake Shaft 3-11

3.9.3 H1gh Voltage Cable Shaft 3-11

3.9.4 Reservolr Vent Shaft 3-11

3.9.5 Heavy Hoist Shaft 3-12

3.9.6 Ventilation Shaft 3-12

3.9.7 Personne1 Shaft 3-13

3.9.8 Shaft Support and Construction 3-13

4. DESCRIPTION OF MAJOR EQUIPMENT 4-1

4.1 Pump-Turbines 4-1

4.2 Spherical Valves 4-1

4.3 Governors 4-1

4.4 Generator-Motors 4-1

4.5 Transformers 4-2

4.6 Generator-Motor Main Leads 4-2

4.7 High Voltage Cable 4-2

4.8 Station Service Power 4-3

4.9 Pump Starting Method 4-3

4.10 Pump Starting Equipment $\quad 4-4$

4.11 Switchyard $\quad 4-4$

5. TRANSMISSION 5-1

5.1 General 5-1

5.2 P1an 1 - Transmission Assessment 5-1

5.3 P1an 2 - Transmission Assessment 5-3

5.4 Summary \& Recommendations 5-4 
6. CONSTRUCTION PROCEDURES 6-1

6.1 Scheme $1 \quad 6-1$

6.2 Scheme 2 6-2

6.3 Construction Schedule - Scheme 1 6-5

6.4 Construction Schedule - Scheme 2 6-6

7. ESTIMATES 7-1

7.1 Basis 7-1

7.2 Cost Summary - Scheme 1 - 12 Hour Storage 7-3

7.3 Cost Summary - Scheme 1 - 10 Hour Storage 7-4

7.4 Cost Summary - Scheme 1 - 8 Hour Storage 7-5

7.5 Cost Summary - Scheme 2 - 12 Hour Storage 7-6

7.6 Cost Summary - Scheme 2 - 10 Hour Storage 7-7

7.7 Cost Summary - Scheme 2 - 8 Hour Storage 7-8

8. SYSTEM STUDY ECONOMICS $8-1$

9. CONCLUSIONS AND RECOMMENDATIONS 9-1

9.1 Engineering 9-1

9.2 Economics 9-1 


\section{ILLUSTRATIONS}

Figure No.

Title

$\begin{array}{ll}\text { 3-1 } & \text { Storage vs. Head } \\ 8-1 & \begin{array}{l}\text { Capacity Factor vs Percent Coal and Nuclear Generation } \\ \text { Uncommitted Pumped Storage vs Breakeven Capital Cost }\end{array} \\ 8-2 & \text { Project General Plan - Scheme } 1 \text { - Sheet } 1 \\ \text { I } & \text { Project General Plan - Scheme } 1-\text { Sheet } 2 \\ \text { II } & \text { Powerhouse Floor Plans - Scheme } 1 \\ \text { III } & \text { Powerhouse - Typical Section - Scheme } 1 \\ \text { IV } & \text { Dike and Intake - Typical Section - Scheme } 1 \\ \text { V } & \text { Project General Plan - Scheme 2 } \\ \text { VI } & \text { Powerhouse Floor Plans - Scheme } 2 \\ \text { VII } & \text { Powerhouse - Typical Section - Scheme } 2 \\ \text { VIII } & \text { Dike and Intake - Typica1 Section - Scheme } 2 \\ \text { IX } & \text { Powerhouse - Plans \& Cross Section - Schemes } 1 \& 2 \\ \text { X } & \text { Construction Schedule - Scheme } 1 \\ \text { XI } & \text { Construction Schedule - Scheme 2 }\end{array}$



SECTION 1. - INTRODUCTION 


\section{INTRODUCTION}

The first marble obtained from the West Rutland site was quarried in 1807. From that time to 1972 , various grades of white to blue have been taken from the site for architectural and monumental purposes. In all, more than 2,000,000 cubic yards have been removed from the West Rutland quarries. In 1972 production of architectural grade marble ceased and the operation was essentially abandoned. The site was eventually sold by the Vermont Marble Company to Stanley Gawett and Stanley Orzeck, the present owners and developers of the property.

The property consists of some 500 acres which include the quarries, the swampland on the West side of Center Road on both sides of the Castleton River to Whipple Hollow Road on the West, to Crecent Street and the Delaware and Hudson property line on the south end and a surveyed line on the North end.

Uses, other than marble production, have been considered, using the property as it presently exists. Amongst these have been fuel oil storage and hydroelectric pumped storage capabilitles. Consequently in 1979, MAIN Investigated the feasibility of construction of a conventional pumped storage project on the Central Vermont Public Services system using the marble quarries as they exist as the lower reservoir with a reservolr constructed on Boardman hill to the East as the upper reservoir. The capacity designed was sufficient to support the future peaking requirements of the combined Vermont utilities.

The unique feature of such an arrangement was the assumption that a substantial amount of the white marble material excavated from the prowerplant and pressure tunnel would be marketable for use in ground products such as fillers for toothpaste, paint materials and other similar products. This would reduce the total cost of the plant by an amount equal to that realized from the sale, and make the unit cost of the pumped storage plant more attractive.

In recent years a great deal of attention has been focused on research and development of the technology required for the construction of high head underground hydroelectric pumped storage. Although underground excavating techniques have been avallable for many years, experfence at great depths has been mostly In deep mine excavations. Several significant studies have however, been made 
which lead to the conclusion that this type of plant is feasible in competent rock and economically competitive with other forms of electric generation.

With the prospect of having at least a portion of the upper reservoir already excavated and the remaining material excavated from the marble quarries having a possible marketable value, it appeared that perhaps substantial savings could be realized from construction of an underground pumped storage project at this site. Realizing that a plant of the size required to prove economically feasible would be much too large for the Central Vermont System alone or even the connected Vermont Utilities together, the New England Power Pool was consulted to determine the effects of a large pumped storage plant on the entire system. Finding that such a plant if economically possible could provide for energy savings on the system, Central Vermont Public Service filed a proposal with the Department of Energy for assistance in funding a prefeasibility study to determine its merit. Financing for the study was granted in late August of 1981.

Since economy of scale reduces the cost per installed kilowatt, it appeared logical to adopt for the study a capacity large enough to be physically and technically feasible at the site and consistent with conventional pumped hydro plant size curently under study on the N.E. System.

Bear Swamp at $600 \mathrm{MW}$ and Northfield Mountain at $1000 \mathrm{MW}$ are the two pumped storage hydroelectric plants which are presently in operation on the New England System. Any additional pumped storage plant would be tentatively placed below these two in the wider part of the load curve depending on relative plant efficiency, and consequently would operate for longer periods of time requiring substantial storage. For these reasons, a $1200 \mathrm{MW}$ capacity was chosen for the underground pumped storage plant and the largest reasonable size reservoir selected as 12 hours of continuous full output generation. These parameters are the basis of the study described herein. 
SECTION 2. - GEOLOGY 


\section{Introduction}

An Important factor bearing on both engineering and economic feasibility of the proposed generating plant is the geology of the area. The complexities of stratigraphy and structure which are scantly exposed at the surface, can only be surmised at the extreme depths proposed for excavation of major plant facilities.

The geologic conditions are therefore described in a tentative manner, with any assurance as to accuracy awaiting the results of a full scale investigation program.

Genera1

The stratigraphy and structure of western Vermont, and specifically the West Rutland area and the Castleton River valley are complex. In spite of more than a century of investigation by numerous geologists, individual interpretations of both structural deformation and stratigraphic sequences vary widely. The major question Involves the nature of the Taconic orogeny, wherein older strata have been pushed from the east over younger beds, Including those of the marble belt. The source area of the older beds has not been determined, or at least not recognized, but it has generally been assumed that they were originally deposited in the vicinity of the Connecticut River Valley.

The question is of more than academic interest with respect to this study, since both the underlying younger rocks and the older strata of the overthrust plate are involved in the proposed project. The economc feasibility of the scheme may be somewhat affected unless a signiflcant amount of the large volume of rock to be excavated from enlargement of the existing quarries, shaft sinking, and tunnel and cavern excavation consists of marketable limestone and marble. In addition, the reaction of the different types of rock and rock structures when excavated after having been subjected to the metamorphism and stresses resulting from the Taconic and other periods of tectonic activity is not known. 
Source data for the study include a number of publications of the Vermont Geological Survey, the results of logging of the deep core boring made specifically for the study, oral communications from former and present geologists employed by the Vermont Marble Company of Proctor, Vermont, and fleld reconnalssance of the area.

\section{SITE DESCRIPTION}

The project area lies in the valley of the Castleton River between a northward extension of Boardman Hill on the east and the eastern slope of the Taconic Range on the west. The intervening valley, approximately 1,500 to $1,800 \mathrm{feet}$ wide, is flat and swampy. The axlal trend of the valley is due north-south and the existing flat surface is apparently due to backfilling by glacier melt run-off.

The elevation of the valley floor is about 495, while the crests of the Taconic Range peaks to the west are somewhat higher than 2,000 feet. The crest of the Boardman H1ll extension on the east is approximately 900 feet.

The inactive marble quarries which would furnish elther the upper reservolr for the underground pumped storage scheme, or the lower reservoir for a conventional pump-generating plant, are located along the toe of the western slope of Boardman H111. The north-south extension of the quarry pits to be connected as a single reservoir amounts to about 4,000 feet. The quarries are strung out along the strike of the marble strata in a north-south 1 ine, and the marble bed excavations have been followed down dip to the east under Boardman Hill at angles ranging from 30 to 45 degrees. Maximum excavated depth of the quarry pits below the surface openings has been estimated to be about 250 feet.

Proposed Scheme 2 would enlarge and use the quarries as the upper reservolr. From the reservoir, a large dlameter power shaft would connect a manifold to the pump-generating plant at a depth of 4,000 feet below the surface, or elevation minus 3,500 feet below sea level. To accommodate the water, and provide a lower reservoir, a sertes of 50 foot diameter parallel tunnels would be driven in an east-west direction for 3,500 feet. Twenty-seven tunnels 
would be required, including the cross tunnels at each end. In addition to the power shaft, several other deep shafts would be necessary, for access, for pressure and vacuum relief, for power transmission, and for rock disposal.

For each plan, the individual quarries would be cleaned out, enlarged, and connected, and a dike would be built along the west side to elevation 560 to enhance the storage capacity.

\section{GEOLOGY OF SPECIFIC FEATURES}

\section{Quarry Reservoir}

Due to the economic importance of the marble layers, the geology of the quarries has been studied in detail and is well documented. The beds which have been mined are on the eastward dipping flank of an anticline which strikes $\mathrm{N}-\mathrm{S}$. Originally the miners extracted only sound stone for ornamental, monumental, and structural purposes, and perforce had to follow the sound layers down deep under the hill, at angles ranging from 30 to 45 degrees.

From the Vermont State geologists report of 1931-32, the total number of marble beds was twenty, with a thickness of 220 to 260 feet. The individual beds ranged in thickness from a minimum of about one foot to as much as 222 feet. The latter was described as graphite marble, and was overlain by 50 feet of white marble. All the rest were relatively thin beds, with different colors and polishing characteristics.

Most of the marble layers quarried for commercial purposes had various impurities, the most important being graphite and muscovite mica. Cores from a deep drill hole made at the quarry site in mid 1981 confirmed these descriptions. The hole penetrated to a depth of 2422 feet below the surface or to about 1925 feet below sea level.

The boring was located near the south end of the Vermont Marble Company quarry pits and about 300 feet west of the openings. The elevation of the ground surface is at about 496. At this point, some 86 feet of valley backfill, 
consisting of sand, grave1 and boulders, both ti11 and outwash, occurs. From that depth to 1,034 feet, the core consisted of calcareous rocks, including marble, limestone, and dolomite, with scattered chlorite, calcite, quartz, and graphite stringers. Below 1,034, the core was primarily schistose, with graphite, talc, chlorite, pyrite and other minerals scattered throughout.

While the outcrops presently visible in the quarry pit wa11s have a massive, sound appearance, with 1ittle structural disturbance with the exception of the eastward dip, examination of the cores below the Burchards 1imestone leve1, around 500 feet, show increasing evidence of flowage, folding and contortion. Fault gouge zones begin to appear below 1,300 feet, and are common throughout the rest of the core.

According to oral communication from Mr. Meade, the geologist retained to supervise the drilling operation and $\log$ the cores, water loss was experienced at about the time the boring was reduced from NX to BX size at 458 feet. After that depth was reached, there was no indication of the depth and the amount of the loss. No pumping in or pumping out tests were made to determine permeability, standing water levels, or quanitites. This was due to the depth of the hole and the lack of proper pumping equipment. The latter factor also prevented determination of the thermal gradient.

Enlargement of and connection of the several quarries requires knowledge of the existing in-situ stresses in the rock. Nearly all of the mining below the surface has been by the room and plllar arrangement, designed by experienced quarrymen with 11ttle other than practical knowledge of rock behavior. Although due to the massive character of the rock and application of experience the majority of the openings and mines have shown little evidence of collapse over the years, at least one of the quarries on this strike belt was reportediy abandoned due to Insufficient pillar support.

With this in mind, it is not recommended that enlargement be accomp 11 shed by removing support pillars, but rather by mining along the strike, using the same general pillar arrangement that has proven to be structurally stable in the past. Such a scheme would also furnish the maximum quantity of marketable stone. 
It is anticipated that there would be little leakage either from or into the reservolrs, based on observations of the water levels presently existing. The major source of any water which might enter the reservoir is expected to be the swamp to the west of the quarriles. The character of the rock barrier between the quarries and the galcially deepened valley under the swamp and the configuration and alignment of the valley walls is not known at this time. Unt11 more and accurate Information is avallable, deepening of and expansion of the quarries to the west to obtain added capacity is not recommended.

Deep Shafts, Underground Caverns and Reservoirs

A deep shaft would be required to convey water from the upper reservolr through the pump-generating plant to the lower reservolr.

The shaft would be bored through the same rock 11thology and structure as shown in the core boring, and probably continue through similar.rock to the full depth of 4,000 feet, unless massive, crystalline basement rocks such as granite occur between 2,422 and 4,000 feet. While such is possible, regional geological relationships render such an occurrence improbable. Assuming therefore, that the conditions actually logged occur to the 4,000 foot level, including intense folding, some faulting wth gouge and brecclation, graphite and talcose beds, etc., lining of the power shaft is recommended. The 11ning may consist of wire mesh and thick shotcrete in much of the shaft, but structural support in the form of relnforced concrete rings and in some cases steel ring girders will be required. A rigid reinforced concrete lining throughout the full depth is not recommended, due to the almost certain existence of in-situ rock stresses at depth, and future effects on such a lining during the operating Iife of the plant.

Other shafts to the full depth include a personnel shaft, a cable shaft, a heavy holst shaft, a rock hoisting shaft, and at least one pressure and vacuum relief shaft.

A11 but the pressure rellef-vacuum relief shaft will be in simllar rock conditions as those described for the power shaft. All, for safety and for maintenance purposes, should be lined with wire mesh and shotcrete, with random placement of rock bolts where needed. 
The vent shaft is located near the southwest corner of the tunnel reservolr grid. At this point it will start in an unknown thickness of glacio-alluvial sediments and till, and the underlying bedrock will be the schists and gneisses which are exposed in the roadcuts for the recently realigned U.S. Rt. 4. At some unknown depth in this shaft, it will penetrate through the Taconic thrust fault zone into the underlying slates, if current structural theories are correct. Based on nearby outcrop observations, the only support required will be rock bolts as needed, although some wire mesh and shotcrete may be necessary during excavation for personnel safety.

Barring unexpected and drastic changes in structure and 11thology, the power tunnel, manifold, penstocks, powerhouse and transformer gallery, draft tube gate gallery, and draft tubes are expected to be excavated in relatively sound schistose rocks like those cored below the 1,000 foot depth.

The water conveyance tunnels will each encounter slightly different rock conditions due to the angle of the dip and the structural deformation of the rock. The power tunne1, drainage gallery, transformer gallery, draft tube gate gallery, and the main discharge tunnel to the lower reservoir will be excavated normal to the strike of the rock strata and will thus cut across beds and other features which are generally in the same plane as the strike and dip, such as faults and shear zones. It is expected that residual stress problems will be less in those excavations which are oriented east-west than those which are aligned north-south, parallel to the strike. Other than rock bolts, 1ining will probably be necessary, in the water tunnels for minimizing maintenance, and 1mproving the friction value, in the personnel and access tunnels for safety. Most of the lining can be wire mesh and shotcrete, although some structural reinforcement may be necessary at some places.

The north-south orlented tunnels, the manifold, penstocks, and draft tubes, will be bored parallel to the strike of the rock, and should be in similar rock the entire length of each. They will also be subjected to maximum rock stress, since they are excavated normal to the maximum stress axis. Lining and support should be as described for the other tunnels, with the minimum use of rigid, non-ylelding reinforced concrete. 
The powerhouse cavern and transformer gallery w11l be aligned east-west to take advantage of the in-situ stress axes. The powerhouse arch will require pattern rock bolting, as will the side and end walls. As both caverns cut across the dip-strike axis, a variety of rock lithology is expected to be encountered from one end to the other.

It is anticlpated that the arch and walls of the caverns will require the wire mesh-shotcrete treatment, for personnel safety if for no other reason.

Any unsound rock found in the caverns, tunnels or galleries is expected to be the result of tectonic activity in the form of brecclation, shearing, etc. Such zones are weak, and even when of limfted extent, need additional support. It is doubtful if any rock deterioration at such depths will be found to be the result of weathering.

The underground reservolr consists of 25 parallel tunnels, 50 feet in diameter, and spaced on 125 foot centers, extending under the valley in an east-west direction for 3,500 feet. On the east and west ends of the tunnels are cross connecting tunnels, aligned north-south. Due to the stress expected to be encountered at this depth, both from vertical load and lateral thrust components, the tunnels are planned to be circular in section.

As with other east-west tunnels, the reservolr tunnels will cut across the strike-dip of the strata and encounter a variety of 11 thologies and structure. In addition, at a distance of perhaps some 2,000 to 2,500 feet west of the powerhouse cavern, the tunnels should encounter the slate and phyllite layers which underlie the Taconic thrust plate.

Tunneling and tunnel support conditions should not be significantly different in the slates and phyllites, compared to the schist beds to the east.

Lining of any part of the reservolr tunnels should be confined to those areas which are found to be unstable during excavation, and which might collapse or cause other maintenance problems during the operational life. 
Upper Reservoir - Scheme 1

The overburden thickness in the upper reservoir dike area has not been investigated, but is expected to range between a few inches to as much as 15 to 20 feet. It is probably composed of thin topsoil overlying coarse till or ground moraine left by melting glactal ice. It consists of silt, sand and minor amounts of clay, as a matrix for cobbles and boulders of various sizes.

The bedrock under the dikes is the phyllite and quartz layers of the Nasssau formation. These rocks, where unweathered, are fully capable of supporting the contemplated loads without significant settlement, nor will sliding stability be a problem.

The vertical power shaft will be sunk from the bottom of the reservoir at E1. 1400 for a depth of 4,000 feet, to E1. -2600 below sea level. Excavation for the first 1,000 feet will be in the phyllites and quartz layers, and at about E1. 400, the shaft will penetrate the taconic thrust fault zone. Below the fault to the bottom of the shaft, excavation will be in slates and phyllites of the Hortonville formation.

The power tunnel from the shaft to the powerhouse will be excavated in the slate for a distance of 5,900 feet, and at a depth of about 3,100 feet below ground surface. Near that point the tunnel bore will penetrate the same varieties of schist as were encountered by the deep core boring below E1. minus 500 .

Tunnel and shaft excavation in the phyllite and slate is expected to be more or less routine once the weathered surface layer is penetrated. Rock bolting will be required in the shaft, with wire mesh and thick shotcrete lining. The rock conditions in the Taconic thrust fault zone are not known at this time, but structural steel or reinforced concrete rings may be necessary for wall support at this point.

The section of power tunnel in slate and phyllite is not expected to need structural support for any significant length. Rock bolts where needed and wire mesh with shotcrete, are recommended. A concrete lining to minimize friction loss will be applied. 
In the section of the tunnel through the schistose rocks, rock bolts and wiremesh with shotcrete will probably be necessary the full length.

Conditions for the powerhouse and reservolr facllitles, including the several shafts, are the same as described in Scheme II.

Spectal Problems - Underground Pumped Storage Scheme

A number of conditions not usually encountered in conventional pumped storage or other hydro plants concern groundwater, including the thermal gradient, the existence of gravity or tectonically induced stresses, and the difficulty of obtaining accurate data regarding any of these factors, arise with the first stages of planning for the project.

Flooding of deep excavations such as the lower reservolr is not an uncommon occurrence, and given the 11 thologic and structural breaks and deformation existing in the area, it is within the realm of possibility that excessive groundwater could be encountered at the 4,000 foot level. Large, continuous inflows could make the project economically unfeasible.

The temperature of the rock at depth could raise stored water heat to the point where it would cause a continuous vapor cloud when pumped to the upper, surface reservoir, at least during the colder months. The thermal gradient at that depth may ralse the temperature from 30 to 50 degrees $F$.

At a depth of 4,000 feet, the welght of the rock column alone amounts to between 4,000 and 5,000 1bs. per square inch. The horizontal stress values may be even higher, as in the northeastern part of the United States, the ratio betwen vertical and horizontal ranges from $1: 1.2$ to $1: 2$. These ratios may possibly be modified downward due to the fact that so much relief has taken place in the past geologic ages along bedding planes and near horizontal faults. The general absence of open jointing other than in surface rock tends to indicate that the rocks are still in compression, rather than in tension, however. 
The difficulty of obtaining accurate data is a direct result of the depth of excavations and the assoclated expense. No inexpensive, simple, or rapid method exists to obtain the necessary information required.

Recommended Investigations - Feasibility Stage

Several rellable maps deplcting surface geology exists, and further attempts to improve or amplify them are unnecessary at this stage. The main effort should be to determine the answers to outstanding questions relative to the rock at depth, insofar as the underground scheme is concerned.

Bore holes, recovering core, should be drilled in the powerhouse area and in the underground reservolr area. Two holes should be drilled in the powerhouse area, while one at each corner and one in the middle of the underground reservolr are proposed. The latter five holes would not have to be cored all the way, but could be drilled by Tri-cone or diamond plug bits to within 200 feet of the tunnel crown, and then finished with a core bit.

A11 of the bore holes would be continually observed for groundwater inflows, static levels, water loss during drilling, and following completion, measured to determine the thermal gradient. The pattern of holes at the corners to the reservoir could then be used with the central hole to obtain information on the orientation and ratios of the stress axes by cross-hole and up-hole seismic velocity measurements. All holes should be logged by gamma and neutron logs, and electric resistivity. The logs furnish important data on rock density, permeability, conductivity, etc. It is also evident that such a program which would, of course, include detailed examination of the cores, would furnish significant details of the structure and stratigraphy and perhaps answer some of the questions now surrounding the Taconic orogeny problem.

W1th respect to Scheme $I$, a few drill holes penetrating into sound rock along the dike lines of the upper reservoir site should be sufficient for feasibility purposes. 
SECTION 3. - PROJECT DESCRIPTION 
PROJECT DESCRIPTION

The required volume of live storage in the reservoirs is dependent on the net head developed between the upper and lower reservoirs and the length of the full load generating period selected. This is of particular 1mportance when considering disposition of the amount of the excavated rock material especially if it is not used in construction of the project features. As 11lustrated on Figure 3 the least underground excavation is obtained under the higher heads. For this project 1 t appeared prudent to select the highest head for which near future technology could produce an operational pump-turbine. EPRI has awarded a contract for investigation and design of a two stage pump turbine for 1200 meters of head and consequently enough assurance was avallable to justify its use by the mid 1990's. Four thousand feet was therefore adopted as the head criteria for the project and the reservoir sized accordingly.

\section{$3.1 \quad$ Lower Reservoir}

To accommodate the selected 12-hour full generation storage required for the $1200 \mathrm{MW}$ plant, a live storage capacity of about 6,700,000 cubic yards must be constructed. In addition to this storage, some provision against overfiling must be provided if the upper reservoir has larger capacity than the lower reservolr. Consequently, a minlmum extra amount of storage equivalent to the excess or about $3 \%$ of the live storage has been added to the amount of live storage. There must also be sufficient water in the lower reservoir, unused for any other purpose than to provide submergence to the turbine to prevent excessive cavitation during the pumping cycle at lowest reservoir elevation and high velocities at the start of a generating cycle. This amount of water lies below the active water storage and is designated dead storage. An additional $5 \%$ of the live storage amount has been added for dead storage. The total excavation for the accumulated storage amounts to about 7,200,000 cubic yards.

The lower reservolr must also be vented to prevent excessive air pressures in the generating cycle and vacuum conditions in the pumping cycle. The air flow required for these conditions is equivalent to the water inflow or outflow. 
The size therefore was selected to limit the air flow velocity in the vent shaft to minimize noise levels. The vent shaft is located at the west end of the reservoir near Route \#4.

\subsection{Lower Reservoir Design}

Review of the cores taken from the drill hole approximately 2500 feet deep done prior to the prefeasibility investigation indicated that marble of varying marketable value occurs in the first five hundred feet. Below that depth, dolomites, schists and gneisses occur at varying depths. From the geologic aspect however, it does appear that the rock formations at the depth of the reservolr and powerplant will be relatively watertight but that compressive strength values may be only in the median range rather than high strength. Excavation of the shafts, underground powerplant and lower reservolr will occur in these formations. This material is not acceptable for ground products use and can only be used as concrete or asphalt aggregates and perhaps in the construction of roads or embankments. Although a small portion of the over six milition cubic yards of this excavation could be used for these purposes, the major portion would have to be spolled.

Because it is expected that the rock at depth is only of median compressive strength, it appears prudent to select an excavated cross sectional shape that is inherently strong for that depth. A fifty-foot diameter tunnel was therefore chosen as a conservatively reasonable size for each of the 25 paralle1 tunne1s comprising the lower reservoir. The tunnels are spaced at 125 feet on centers and are oriented in a roughly East-West direction which it is assumed is the direction of maximum horiontal tectonic stress. The tunnels have been designed to slope up a grade of $2 \%$ from the East collector tunnel to the West. A cross collector tunnel, 30 feet in diameter connects the ends of the reservoir tunnels at each end. The collector tunnel on the West end is located with the crown concident with the top of the reservoir tunnels. The vent shaft is constructed from the surface to this tunnel. The invert of the collector tunnel on the East is colncident with the invert of the reservoir tunnels.

To maintain submergence on the pump-turbine units the draft tube collector tunnel to which the discharge of each pump-turbine draft tube tunnel is 
connected, slopes up from draft tube tunnel \#4 to the minimum live storage elevation. Access to the reservolr for inspection is obtained from the powerplant through gated accessways from the draft tube gate gallery.

\section{$3.3 \quad$ Upper Reservolr}

Two conflgurations have been considered for the upper reservolr. One using the existing quarries with enlargement and the second utilizing the material excavated from the lower reservolr to construct an Impounding dike on the hill to the west of the site. In either case, the lower reservolr is identical.

The Inactive quaries as they exist with a surface elevation at approximately elevation 500 were mined for dimension stone unt11 about 1972. During the time of active use, approximately 2,000,000 cublc yards have been removed. To meet the requirements of 12 hours of storage for the proposed project an additional 4.8 million cubic yards must be removed. To do this the quarries must be connected and expanded. It is estimated that as much as $60 \%$ of the material excavated from the quarry area will be of comerical value. The remaining $40 \%$ will have to be disposed of in either the construction of the project features or in a sultable disposal area to minimize the cost of the upper reservolr. The storage in this alternate was therefore made up of excavation of a portion of the area surrounding the marble quarries amounting to approximately 3,482,000 cubic yards, and constructing a dike around the perimeter from El. 500 to E1. 560 uslng commerclally unsultable spoll material from the excavation to provide the remaining 3,376,000 cubic yards of storage. A reinforced concrete liner is applied to the inside face of the dike.

Material excavated from the reservolrs not used in the construction of the project must be deposited in a sultable disposal area close to the site to minimize the cost of hauling. Lowlands frequently flooded adjacent to the Castleton River and the project site was selected for this purpose. Approximately 200 acres would be used with an average depth of 30 feet. This reclalmed area would make an excellent industrial site and its sale for the purpose could further reduce the cost of the project. 
The second alternative considered was to utilize the top of the mountain to the south of the Castleton RIver near Route 4 as the site of the upper reservoir. Since most of the material excavated from the underground facilities appears to be of little or not commercial value, an attempt was made to utilize all of the material from this source in the construction of the reservoir dikes. To contain the required power storage and minimfze the height of the dikes, the top of the mountain from Elevation 1400 to Elevation 1440 is removed and incorporated in the dike section. Since no exploration has been done in this area, the amount and quality of the soll material covering the mountain is unknown, but it is expected that insufficient material to construct an impervius core is avallable, however all of the excavation is incorporated in the dikes or access roads.

The dike cross section consists of a compacted rock fill to a maximum height of 125 feet with a reinforced concrete surface applied to the interior face.

Rock removal from the underground reservoir excavation must be done through the power tunnel and intake shaft. For this reason the tunnel and shaft have been enlarged from the designed 18 feet to 21 feet to accommodate construction traffic. The intake shaft is located at the northern end of the reservolr and is connected to the powerplant by a tunnel about 5,900 feet long. In addition, a drift was excavated between the tunnel and the cross connector tunnel on the East end. The proposed construction sequence and type of hoisting equipment 1s described in "Proposed Construction Methods".

In both alternates the surface bullding complex, and transmission substation and the powerplant access shafts are located on the high ground to the East near the marble quarries. The major advantage of Scheme 1 , is that 1 t requires no disposal of excavated materials except in project features and all shafts except the intake are approximately 800 to 1,000 feet shorter than in Alternate 2. In addition, removal of the marble material can proceed at a pace commensurate with ground product production but does not provide a cost advantage due to excavation of the marble. Its major disadvantage is access to the mucking shaft onthe mountain during the winter months. A constant patrol may be required for snow removal and sanding and may cause slowdowns in getting personnel to and from the mucking shaft. 
In Alternate 2 excavation of the marble for the upper reservoir storage has substantial commercial value which to some extent reduces the total cost of construction. The access shafts on the other hand are 800 to 1,000 feet longer and the rock excavated from the lower reservolr must be disposed of in the swanplands. If, however, the reclaimed land obtained from deposition of the excavated materlal from the lower reservoir in the lowlands has value for industrial development, it can also reduce the total capital investment in the project.

\section{$3.4 \quad$ Intake}

The intake in the upper reservolr for Alternate 2 is constructed as a slot in the side wall of the marble quarry known as Main \#1. The Intake shaft 21 feet in diameter is connected from the bottom of the intake structure to the water tunnel and manifold. The Intake Tower is controlled by head gates at the bottom of the upper reservoir. The concrete walls of the Intake are extended to the surface and covered by a steel grating floor to act as an air vent. Access is obtained by means of a steel and concrete bridge to the gate holst mounted at the top of the tower.

The intake for Alternate 1 is simllar, except that the Intake walls are constructed from the rock surface at the toe of the upper dike.

\subsection{Powerplant Complex}

The major features of the powerplant complex are the powerplant cavern, the transformer gallery and the gate gallery together with the tunnels and adits to which they are connected.

The powerplant cross sectional excavation, relative location of transformer and gate galleries, submergence on the units and all other features are 1dentical for both scheme configurations except that on Scheme 1 the powerplant operating floor elevation lies 3,100 feet below the ground while in Alternate 2 it is set at 4,100I feet. This affects only the length of the access shafts and the equipment contained in them. 


\subsection{Powerplant}

The powerplant cavern is designed as an elliptical shape 190 feet from the crown to the bottom of the draft tube excavation with a maximum width of $80^{\prime}$. Including the erection bay, the length of the cavern is 410 feet.

Support for the walls and roof is by means of rock bolts, wire mesh and shotcrete. Although these have not been designed, adequate provision has been made in the estimates to cover the cost.

The cavern is connected to the heavy hoist shaft by an adit 25 feet wide by 30 feet high. Length from the center of the heavy hoist shaft to the excavated face of the erection bay is 90 feet.

\subsubsection{Machine Hall}

The powerplant cavern is located with the operating floor at E1. $-2,640$ in Scheme I and E1. -3,597 in Scheme II. It contalns four vertical shaft two-stage reversible Francis type pump turbines, each capable of producing 415,000 h.p. at $720 \mathrm{r} \cdot \mathrm{p} . \mathrm{m}$. under expected minimum net head of 4,000 feet. They will require about $462,000 \mathrm{~h} . \mathrm{p}$. of pumping power at minimum T.D.H. of 3,000 feet. The units are located 100 feet below minimum tallwater in the lower reservolr to prevent cavitation. 011 pressure operated spherical valves are provided upstream of each spiral case to minimize leakage when the unit is not in operation and to enable repalrs to the turbine. Each unit will be controlled by a turbine governor.

Each of the four pump-turbines is directly connected to a 3 phase 60 hertz, vertical shaft generator-motor capable of producing $300,000 \mathrm{KW}$ at .9 power factor with a maximum of $60^{\circ} \mathrm{C}$ rise and producing maximum pumping power of $462,000 \mathrm{~h} . \mathrm{p}$. at unity power factor with a maximum of $80^{\circ} \mathrm{C}$ temperature rise. Pump starting is accomplished with static converter equipment located adjacent to Unit \#1 under the Erection Bay floor. 


\subsubsection{Electrical Gallery}

The electrical gallery located below the operating floor level contains the low voltage bus, phase reversal switches, 1ow voltage clrcult breakers, potential transformers, and the D.C. boards. The static converter starting equipment is located on the same floor but is located under the erection bay floor in the service bay.

\subsubsection{Turbine Gallery}

The turbine gallery below the electrical gallery houses the turbine governors and oil tanks, air depression tanks, and some minor operating eq1pment.

The upper runner, upper headcover and gate mechanism are installed and removed from above at this gallery in a similar manner to a conventional machine. Because of the relatively high speed, the compact diameter of the motor-generator bore is too small for removal of a one plece head cover. Some modificaiton to the turbine barrel at this floor must therefore be made. An access opening in the side of the barrel on the longitudinal centerline sufficlent to allow these parts through is therefore provlded at adjacent units. A transfer car w111 transport the runner, and head cover to a position between units so that the main crane can remove these pleces through hatches to the operating floor.

\subsubsection{Spherical Valve Gallery}

The lowest gallery houses the five foot diameter spherical valves, the valve operators and the hydraulic systems to operate them. Draft tube access is also obtained at this level.

The lower runner, lower head cover and the removable section of the draft tube must be installed and removed from below and thus requires access in a similar manner to that used for the upper headcover and runner. The transfer car described above is used for removal of the parts to the vertical access between adjacent untts. 


\subsubsection{Erection and Service Bay}

An erection and service bay is located between the end of the heavy hoist shaft adit and Unit \#1. The adit is equipped with rails matching those on the heavy hoist platform so that the car supporting the major powerplant equipment can be rolled from the hoist to a convenient point on the erection bay floor under the bridge crane used to service the powerplant.

Galleries below the erection bay floor level contain the oil purifying systems and clean and dirty oil tanks, compressors for the station air and generator braking ssystems, the station dralnage sump, unit cooling water systems, potable water systems and waste treatment, and the station ventilating system.

For erection, dismantling and servicing the pump-trubines, generator-motors, and spherical valves, a bridge crane of 250 tons capacity, is mounted on rails, supported by structural steel columns above the generator floor. Because of the slow speed and large lifting capacity of the main crane, an auxiliary bridge crane of 25 tons capacity is mounted on rails supported by brackets from the main crane columns below the main crane. This crane is provided for servicing and moving some of the smaller auxiliaries.

\subsection{Transformer Gallery}

The transformer gallery is arranged to be directly above the powerplant and vertically separated from it by a dimension equivalent to the width of the powerplant cavern. It is also elliptical in cross section with the crown at Elevation $-2,425$ in Scheme I and $-3,382$ in Scheme II. From invert to crown it is 50 feet in height by 60 feet maximum width. Total length is designed as 490 feet. From the centerline of heavy hoist shaft to face of transformer bay is 80 feet.

Support is provided in a similar manner to the powerplant cavern. It is designed to contain two banks of three single phase transformers, forced o1l, water cooled, with a 30 rating of $700 \mathrm{MVA}, 18 / 360 \mathrm{kV}$. The low voltage output from two generating units is connected to one bank of three single phase transformers by isolated phase bus through a bus tunnel and shaft arrangement connecting 
the two galleries. Each generator can be 1solated from the transformer bank by disconnect switches so that maintenance can be performed on any pumpgenerating unit.

Single phase transformers were selected because of weight consideration. The transformers will be mounted on double flanged wheels that can be jacked and rotated $90^{\circ}$ so that they may be rolled on rails into place in the transformer gallery. When belng delivered to or removed from the surface to the transformer gallery, the transformers are rolled to the ralls on the holst platform.

Each transformer will be isolated by fireproof walls with removable fire resistant panels in front of each transformer to permit placement and removal. A low pressure $\mathrm{CO}_{2}$ fire extingulshing system will be used for fire protection. To 1solate smoke, separate evacuation systems will be used for each transformer vault.

A collecting sump filled with crushed rock is provided under each transformer. Each sump is sized to contain the entire oil content of the transformer above it, in the event of a leak in the tank. A holding sump at the end of the gallery is connected to the drains under each transformer.

\subsubsection{Generator-Motor Leads}

The main leads between the generator-motors and the main step-up transformers are isolated phase bus type with factory fabricated bus and housing. They run from the output terminals on the generator-motor through the phase reversing switches on the operating floor and the low voltage circuit breakers located in the leads adit upstream of each generator. The leads rise vertically through the vertical shaft to the transformer adit and horizontally to the low voltage terminals on the transformers. To maintain and service the leads, a service elevator is provided. 


\subsubsection{High Voltage Cables}

$345 \mathrm{kV}$ high voltage $\mathrm{SF}_{6}$ gas insulated bus, is connected from each bank of step up transformers through disconnect switches and lightning arrestors to the substation at grade, through the high voltage cable shafts. At the surface the high voltage leads terminate in high voltage potheads at the center of the swtichyard. Servicing of the high voltage leads is provided by an elevator that can be controlled to stop at any elevation required.

\subsection{Draft Tube Gate Chamber}

Draft tube gates are provided for closing each of the tallrace tunnels so that the turbines can be dewatered for inspection and maintenance. The gates are fabricated in two sections with appropriate rubber seals between them bolted together in the gate gallery before depositing in the draft tube gate slot. In their permanent location the gates rest on dogging devices in the gate slot at the gate chamber floor. When needed to dewater a pump-turbine untt, the gate is lifted clear of the dogs and deposited in the tailrace tunnel slot by means of a lifting beam attached to the crane holst.

The floor of the gate chamber is located above the highest point in the reservoir at the elevation of the transformer gallery and is connected to it by an access adit. The gate chamber is equipped with a travelling bridge crane mounted on rails at sufficient height above the floor to permit movement of the assembled gates and to allow transport to the transformer gallery and removal to the surface by the heavy holst should the need arise.

\subsection{Permanent Shafts}

\subsubsection{Requirements}

To construct and operate an underground hydroelectric pumped storage project, several vertical shafts must be constructed, a water intake shaft to carry water to and from the pump-turbines, access for personnel and materials, a high voltage cable shaft from the transformers to the surface switchyard, a ventilation 
shaft for the lower reservolr to provide inflow and outflow of air during the pumping and generating cycles, a ventilation shaft for the powerplant complex and a heavy holst shaft to provide access for the heavy powerplant equipment.

\subsubsection{Water Intake Shaft}

The water intake shaft is designed to convey water from the upper reservolr to and from the pump-turbine. The shaft size was designed to carry a maximum flow of $3939 \mathrm{cfs}$. for the $1200 \mathrm{MW}$ plant at a net head of 4000 feet. The finished diameter of the shaft is 21 feet. Some support will be required. This will be done with rock bolts and shotcrete. The finished concrete lining has been set at 18 inches in thickness.

\subsubsection{High Voltage Cable Shaft}

Two $345 \mathrm{kV}$ high voltage clrcuits from the high voltage terminals of the transformer to the surface switchyard are planned. The cable will be $\mathrm{SF}_{6}$ gas insulated, isolated phase type bus supported from the walls of the shaft. Since insulation is dependent on the gas contained enclosures, the pressure must be monitored periodically to insure that there is sufficient gas. For this purpose an elevator to carry maintenance personnel and gas cylinders must be provided. The finished diameter of the shaft was therefore chosen as 18 feet to accommodate these functions. Rock bolts and shotcrete support will be required for this shaft.

\subsubsection{Lower Reservoir Vent Shaft}

A ventilation shaft to provide air inflow and outflow from the lower reservolr is required during the pumping and generating cycles. The amount of air moved is equivalent to the amount of water moved. This shaft is located with the exit on the high ground near Route 4 on the Western side of the reservolr and comes to the high point in the West Collector Tunnel of the lower reservoir.

For the purpose outlined, the size of the ventilation shaft can be minimal based on velocities of approximately 50 feet per second for the air. This would require about a 12 foot diameter bore reduced by shotcrete protection. 
This size is difficult to excavate to the depths required (approx. $3890 \mathrm{feet}$ ) and from experience, no less than 15 feet diameter should be considered because the cost differential from the labor aspect is essentially nil.

\subsubsection{Heavy Holst Shaft}

The heavy hoist shaft is designed to transport the largest and heaviest pleces of equipment from the surface to their final position in the underground powerplant complex. The major equipment includes pump-turbine and motor-generator parts, the spherical valves and the transformers.

The shaft has been designed to contain both the heavy holst and a smaller faster speed elevator for movement of small, lighter equipment.

The heavy holst platform is guided for its full height by permanent rigid guides. The platform is equipped with permanently mounted rails set at the gage selected for the transformer wheels. This arrangement provides a sultable car, on which the equipment to be moved is placed, that can be locked in place on the hoist platform. At the surface, the car can be moved on rails from the hoist platform under the steel supported bridge crane which transfers the load to the car. The car is then moved to the hoist platform from where it can be delivered in a similar manner at its final location in the powerplant complex.

Besides the ground surface, the hoist is designed to stop at the transformer gallery, the powerplant operating floor and the spherical valve gallery. Short drifts from the end of each gallery connect to the heavy holst shaft and are equipped with rails matching those on the hoist platform.

\subsubsection{Ventilation Shaft}

The temperature below the surface rises at a rate of $1^{\circ} \mathrm{C}$ to $3^{\circ} \mathrm{C}$ per 100 meters of depth, depending on location. For this area it appears that the lesser amount is reasonable. The normal temperature at this depth is therefore predicted at between $80^{\circ}$ and $100^{\circ}$ Fahrenheit. In order to maintaln a reasonable working temperature some refrigeration of the ambient air must be introduced. A separate 
ventilation shaft has therefore been considered as an essential element of the project. Fans and refrigeration equipment are contained in a building at the surface.

\subsubsection{Personne1 Access}

It is expected that this plant will be operated remotely from the New England Power Distribution Center in West Springfield, Massachusetts. Minimum support personnel are expected to be required at this installation, however, during periodic maintenance and major overhaul of the pump-turbine and/or motor generator significantly more personnel are required. For this reason the shaft has been designed to accommodate an elevator sized to carry as many as 30 workers at a time. Recognizing that time in an enclosed space such as an elevator may appear to be considerably longer, the elevvator speed was selected to be the fastest avallable within comfort range. Twenty-five hundred feet per minute was therefore selected for the elevator speed.

\subsubsection{Shaft Support and Construction}

At depths greater than 500 feet, horizontal tectonic forces may exceed those produced by vertical loading alone. From geologic inspection of the core which was driven to on $1 \mathrm{y} 60 \% \pm$ of the depths proposed, it appears that support must be provided in the way of rock bolts, shotcrete, reinforced with wire mesh and in the lower elevations by structural concrete. These measures are suggested for all shafts although in greater measure in those dedicated to movement of personnel and the continued operation of the plant. The most important considerations should therefore be concentrated on Personnel access, the H.V. cable shaft and the heavy hoist equipment shaft. For these, a concrete 1 ining at a thickness of .07 times the diameter but no less than a nomlnal 12 inches will be used. 


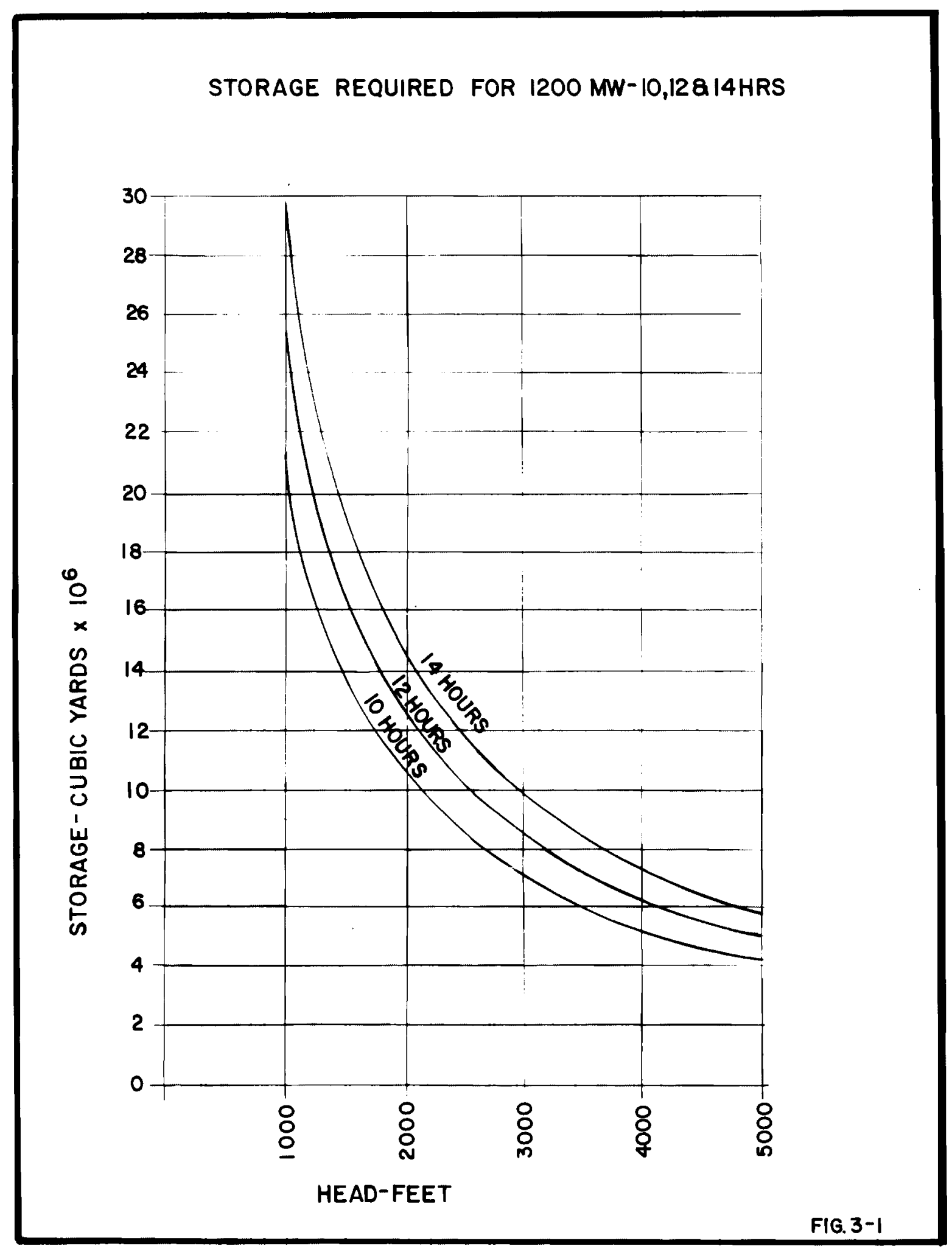


SECTION 4. - DESCRIPTION OF MAJOR EQUIPMENT 


\section{DESCRIPTION OF MAJOR EQUIPMENT}

\subsection{Pump-Turbines}

The four two stage reversible pump-turbines are designed to produce 415,000 H.P. at 720 R.P.M. under 4,000 feet head. This will produce the rated $300 \mathrm{MW}$ at the generator terminals. In each pump turbine the two runners are coupled to a common vertical main shaft and water passes from one runner to the other by a diffuser section. At the turbine entance to the upper runner, adjustable wicket gates are provided controlled by a gate mechanism located in the turbine pit.

\subsection{Spherical Valves}

A 60 inch diameter spherical valve is installed in each pump turbine at the entrance of the spiral case. It will be hydraulically operated with both upstream and downstream seals and be equipped with an air oil operating system.

\subsection{Governors}

The governors are electric-hydraulic type single actuator, oil pressure, pilot operated cabinet actuator type with electrically driven speed responsive elements.

\subsection{Generator/Motors}

The generator/motors w1ll be rated $300,000 \mathrm{~kW}, 333 \mathrm{MVA}, 720 \mathrm{rpm}, 0.9$ power factor and a tentative voltage of 18,000 volts. The generator/motors 11e beyond extremes of actual experfence, at this speed but manufacturers have completed preliminary designs and advise that this rating is within the capabilities of present day technology. Large high speed units presently installed are as follows:

$\begin{array}{llll}\text { Wehr and Hornberg Projects } & 290 \mathrm{MVA} & 600 \mathrm{rpm} & \text { horizontal } \\ \text { Dnorwic } & 330 \mathrm{MVA} & 500 \mathrm{rpm} & \text { vertical } \\ \text { Okuyoshimo } & 220 \mathrm{MVA} & 514 \mathrm{rpm} & \text { vertical } \\ \text { Chiotas-Plastra } & 170 \mathrm{MVA} & 600 \mathrm{rpm} & \text { vertical } \\ \text { Maltz } & 220 \mathrm{MVA} & 500 \mathrm{rpm} & \text { vertical } \\ \text { Ohira } & 265 \mathrm{MVA} & 400 \mathrm{rpm} & \text { vertical }\end{array}$


The generator/motors would be designed with a combined thrust and guide bearing above the rotor, and a guide bearing below. The stator and rotor would be expected to be direct water cooled to reduce size and weight but the cooling method would require further study during the detail design.

\subsection{Transformers}

The main power transformers will consist of two banks of single phase transformers with a three phase rating of approximately $700 \mathrm{MVA}, 18 / 360 \mathrm{kV}$ forced-oil forcedwater cooled (FOW). The rating will be determined by the pumping load of two units, the station service power and static excitation load of four units and the short time load of the converter starting unit.

The FOW cooling will provide the lowest welght transformer and the water cooling is the most economical means of removing the heat of the transformer in an underground cavern.

\subsection{Generator/Motor Main Leads}

The generator/motor main leads will consist of self-cooled and/or forced cooled isolated phase bus. The main leads will connect the generator/motors to the main power transformers and w111 include the phase reversing switches, connections to the unit circuit breakers, surge protection and potential transformer cubicles, tap buses to the station service power transformers and tap buses with disconnect switches to the circuit breaker in the supply connection to the static converter.

\subsection{High Voltage Leads}

The high voltage leads will connect the three single phase transformers of a bank together and run up the vertical shaft and connect to the switchyard. The high voltage leads will consist of sulphur hexafluoride $\left(\mathrm{SF}_{6}\right)$ gas insulated bus. Gas insulated bus is the only feasible equipment for a vertical installation of the required height. 


\subsection{Station Service Power System}

Station service power will be provided by two transformers, each connected to the low voltage bus of the main power transformers. Each station service power transformer will supply power to an assembly of metalclad switchgear. The voltage of the switchgear and assoclated equipment will be 13,800 or 4160 volts as determined by study during the detall design of the project.

Each assembly of metalclad switchgear will supply power to static excitation for two generator/motors and 480 volt secondary unit substations. A normally open, automatically closed tie will be provided between the two assemblies of metalclad switchgear. Normal open, automatically closed ties will also be provided between 480 volt buses of the secondary unit substations.

\subsection{Pump Starting Method}

Several methods for starting the pump/turbines in the pumping mode were explored for the West Rutland quarry underground pumped storage project. Two of these can be eliminated immediately. Wound rotor pump motors are not a credible solution for untts this size and speed because of design and operating limitations. Across the line starting, whether full or reduced voltage is used, is at least questionable due to both design limftations of the generator/ motor and the voltage drop in the electrical system. The only feasible pump starting schemes for generator/motors of this rating and speed appear to be (1) synchronous or seml synchronous starting back to back from another generator or (2) synchronous start from a variable frequency static convertor unit. Back to back starting from another generator does not appear feasible for this project because using a unit in the station only allows the use of three pumps and there is no unit outside the plant of this capability that could be used to start all four. The design therefore is based on the most feasible starting method, a variable frequency static converter starting scheme. Equipment and circultry is however provided to permit back to back pump starting of a unit from Unit No. 1 or No. 4 as a standby means of starting in the event of fallure of the static converter unit. 
The static converter starting equipment will be provided with supply connections from each of the two main power transformer secondaries. A disconnect switch will be provided in each of the two connections and a circuit breaker will be provided in the common connection to the converter unit. The circuit breaker will trip for any fault in the converter and prevent tripping of the associated transformer and generators.

The static converter will be connected to a starting bus through a circuit breaker. Connections from the starting bus to each unit will be made between the phase reversing switch and circuit breaker of each unit. The connection to units two and three will be through a disconnect switch and the connection to units one and four will be through a circuit breaker. The installation of circuit breakers in the connections to units one and four is to permit either of these two units to be used as generators for back-to-back pump starting of other units.

\subsection{Switchyard}

The swltchyard will be a four breaker $345 \mathrm{kV}$ ring bus with connections for the two transformer circuits and for transmission lines to Coolidge and Champlain Substations. The switchyard will be an outdoor station with air blast or gas insulated circuit breakers. Protective relays and local control equipment will be installed in a control house in the switchyard. 
SECTION 5. - TRANSMISSION 


\section{$5.1 \quad$ Genera1}

For the installed capacity at the West Rutland site, the existing transmission system will be insufficient to carry the full pumping or generating loads. For this reason, studies were performed to investigate the routes and cost of the required additions.

Testing was conducted at a peak load of 22,130 MW which corresponds to the New England forecast for the 1993/94 winter, the earliest date the project could be operational. Additional testing was conducted at a $45 \% 1 \mathrm{oad}$ level in the pumping mode. To determine the most desireable route two alternate schemes were considered. In both cases it was assumed that the $345 \mathrm{kV}$ base transmission in Vermont is as shown on Figure 5-1, and that $345 / 115 \mathrm{kV}$ autotransformers are in service at Vernon, Coolidge, West Rutland and Champlain substations. Two short lines tie the pumped storage hydro facility to the West Rutland $345 \mathrm{kV}$ bus.

\subsection{P1an 1 - Transmission Assessment}

Heavy Load Condition

The New England system is simulated at a load level of $22130 \mathrm{MW}$. Imports are: Hydro-Quebec $1000 \mathrm{MW}$, New York $150 \mathrm{MW}$, and New Brunswick $230 \mathrm{MW}$. The West Rutland pumped hydro is generating 1 ts full capacity of $1200 \mathrm{MW}$.

Need for Transmission Additions

Second West Rutland-Coolidge $345 \mathrm{kV}$ Line

Loss of the Initial West Rutland-Coolidge $345 \mathrm{kV}$ line causes overloads on both the West Rutland $345 / 115 \mathrm{kV}$ auto transformer and the $115 \mathrm{kV}$ circuit to Coolidge ( $63 \%$ of the pre-contingency West Rutland-Coolidge f1ow appears on the parallel $115 \mathrm{kV}$ circult after the outage). 
Second Coolidge-Vernon $345 \mathrm{kV}$ Line

This analysis assumes the second West Rutland-Coolidge $345 \mathrm{kV}$ line is in service. Loss of the Coolidge-Vernon $345 \mathrm{kV}$ 1ine causes overloads on the $115 \mathrm{kV}$ support circuits. Forty-eight percent of the pre-contingency Coolidge-Vernon flow is added to the Coolidge-Ascutney $115 \mathrm{kV}$ circuit loading.

\section{Light Load Condition}

The New England system is simulated at a load level of 9959 MW (45\% of 1994/93 winter load) and 1mporting $1000 \mathrm{MW}$ from Hydro-Quebec, $75 \mathrm{MW}$ from New York, and 230 MW from New Brunswick. The West Rutland pumped hydro station is pumping its full capacity of 1200 MW.

\section{Need for Transmission Additions:}

Second West Rutland-Coolidge $345 \mathrm{kV}$ Line

Loss of West Rutland-Coolidge $345 \mathrm{kV}$ line causes overloads on the GrantteComerford $230 \mathrm{kV}$ 1ine and Champlain $345 / 115 \mathrm{kV}$ clrcults supporting West Rutland are in excess of their emergency ratings.

Second Coolidge-Vernon $345 \mathrm{kV}$ Line

This analysis assumes the second West Rutland-Coolidge $345 \mathrm{kV}$ line is in service. Loss of the Coolidge-Vernon $345 \mathrm{kV}$ line causes overloads on the Blissville-Whitehall $115 \mathrm{kV}$ line and other circuits and the Coolidge $345 / 115 \mathrm{kV}$ auto transformer.

Second West Rutland-Champlain $345 \mathrm{kV}$ 11ne and $345 / 115 \mathrm{kV}$ Auto Transformer at Champlain Station

This analysis assumes the second West Rutland-Coolidge $345 \mathrm{kV}$ 1ine and the second Coolidge-Vernon $345 \mathrm{kV}$ line are in service. Loss of the Champlain $345 / 115 \mathrm{kV}$ auto transformer or loss of the West Rutland-Champlaln $345 \mathrm{kV}$ line causes overloads on the Essex-Williston $115 \mathrm{kV}$ line. This overload 
appears only at light load periods when summer ratings are in effect; even then the loading exceeds emergency ratings by about $12 \%$.

Alternatives to adding the second West Rutland-Champlain $345 \mathrm{kV}$ line and the second $345 / 115 \mathrm{kV}$ auto transformer at Champlain are:

1. Reconductor the 25 mile section of the Essex-Williston $115 \mathrm{kV}$ line now conductored with $336 \mathrm{MCM}$. This section is the limiting element for summer conditions.

2. Reduce the import from Hydro-Quebec for the loss of West RutlandChamplain $345 \mathrm{kV}$ line or the loss of the Champlain $345 / 115 \mathrm{kV}$ auto transformer.

3. Open the Essex-Williston $115 \mathrm{kV}$ line for loss of West Rutland-Champlain $345 \mathrm{kV}$ 11ne or the loss of the Champlain $345 / 115 \mathrm{kV}$ auto.

\subsection{Plan 2 - Transmission Assessment}

\section{Heavy Load Condition}

The New England system is simulated at a load level of $22130 \mathrm{MW}$ and importing 1000 MW from Hydro-Quebec, 150 MW from New York, and 230 MW from New Brunswick. The West Rutland pumped hydro 1s generating 1ts full capacity of $1200 \mathrm{MW}$. .

\section{Need for Transmission Additions:}

Second West Rutland-Coolldge $345 \mathrm{kV}$ Line

Loss of the Initlal West Rutland-Coolidge $345 \mathrm{kV}$ line causes overloads on both the Wet Rutland $345 / 115 \mathrm{kV}$ auto transformer and the $115 \mathrm{kV}$ circult to Coo11dge.

Second Cool1dge-Vernon $345 \mathrm{kV}$ Line

This analysis assumes the second West Rutland $345 \mathrm{kV}$ 11ne is in service. Loss of the Coolldge-Vernon $345 \mathrm{kV}$ line causes overloads on the $115 \mathrm{kV}$ support circults. 
Light Load Condition

The New England system is simulated at a load level of 9959 MW (45\% of 1994/93 winter load) and importing $1000 \mathrm{MW}$ from Hydro-Quebec, $75 \mathrm{MW}$ from New York, and 230 MW from New Brunswick. The West Rutland pumped hydro station is pumping its full capacity of $1200 \mathrm{MW}$.

Need for Transmission Additions:

Second West Rutland-Coolidge $345 \mathrm{kV}$ Line

Loss of the Initial West Rutland-Coolidge $345 \mathrm{kV}$ line causes overloads on the Granite-Comerford $230 \mathrm{kV}$ line and Champlain $345 / 115 \mathrm{kV}$ auto transformer. Also, the loadings on the $115 \mathrm{kV}$ circuits supporting West Rutland are in excess of their emergency ratings.

Second Coolidge-Vernon $345 \mathrm{kV}$ Line

This analysis assumes the second West Rutland-Coolidge $345 \mathrm{kV}$ ine is in service. Loss of the Coolidge-Vernon $345 \mathrm{kV}$ line causes overloads on the Blissville-Whitehall $115 \mathrm{kV}$ line and other $115 \mathrm{kV}$ clrcults and the Coolidge $345 / 115 \mathrm{kV}$ auto transformer.

\section{$5.4 \quad$ Summary}

Comparing the two alternative plans, the primary support transmission required in both plans is the second West Rutland to Coolidge $345 \mathrm{kV}$ and the second Coolidge to Vernon $345 \mathrm{kV}$ 1ines. The difference in the two alternative plans is the path to Champlain which is required because of marginal overloads on the Essex-Wiliston $115 \mathrm{kV}$ line. Plan 1 meets first contingency criteria. Plan 2 results in heavy loadings on the $230 \mathrm{kV}$ line from Comerford to Granite at light load while importing from Hydro-Quebec and pumping at West Rutland. P1an 2 results in constraints on the system operation and is less feasible due to cost of the reinforcements and the environmental aspects associated with opening a new $345 \mathrm{kV}$ right-of-way corridor. 


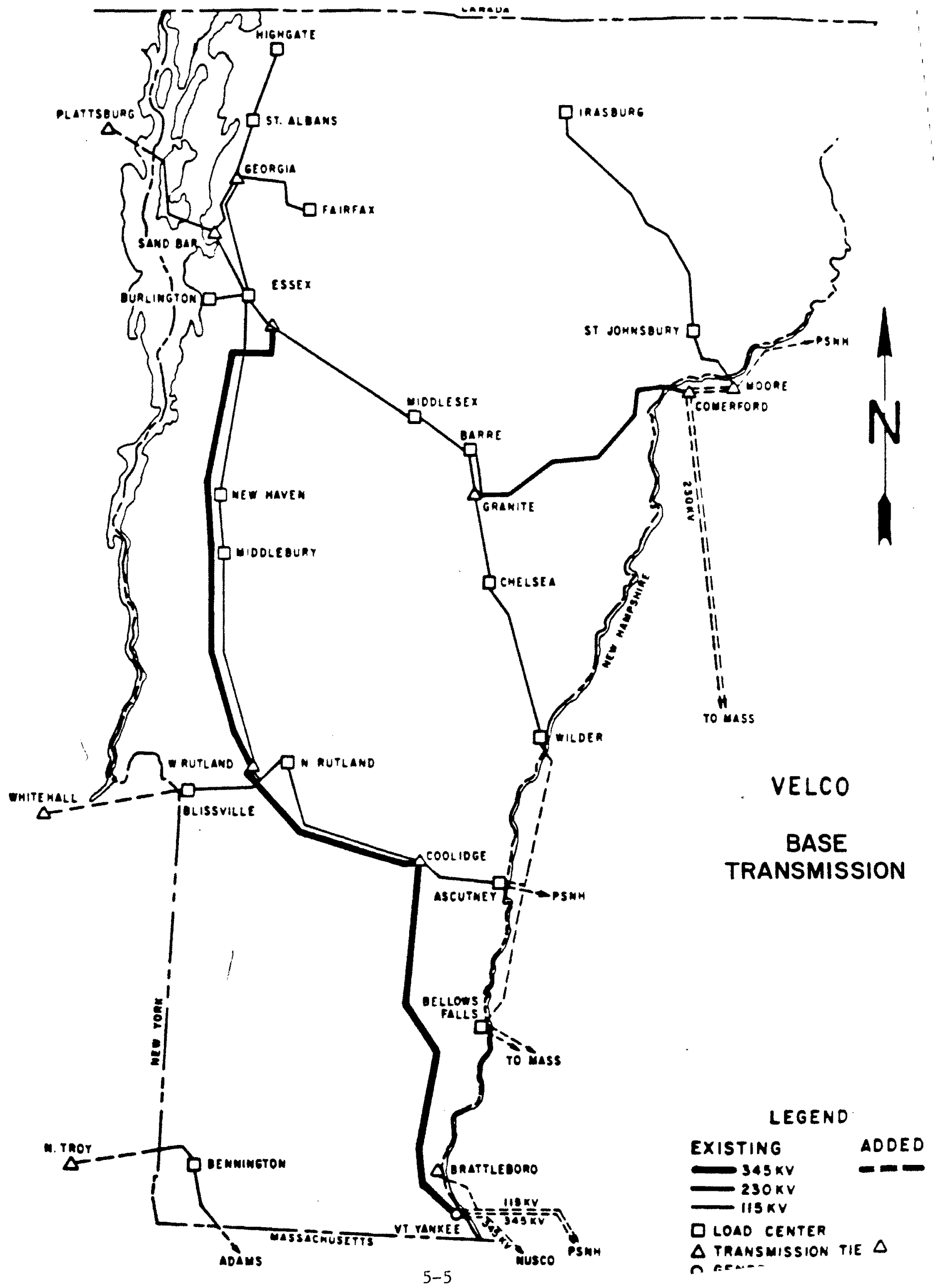




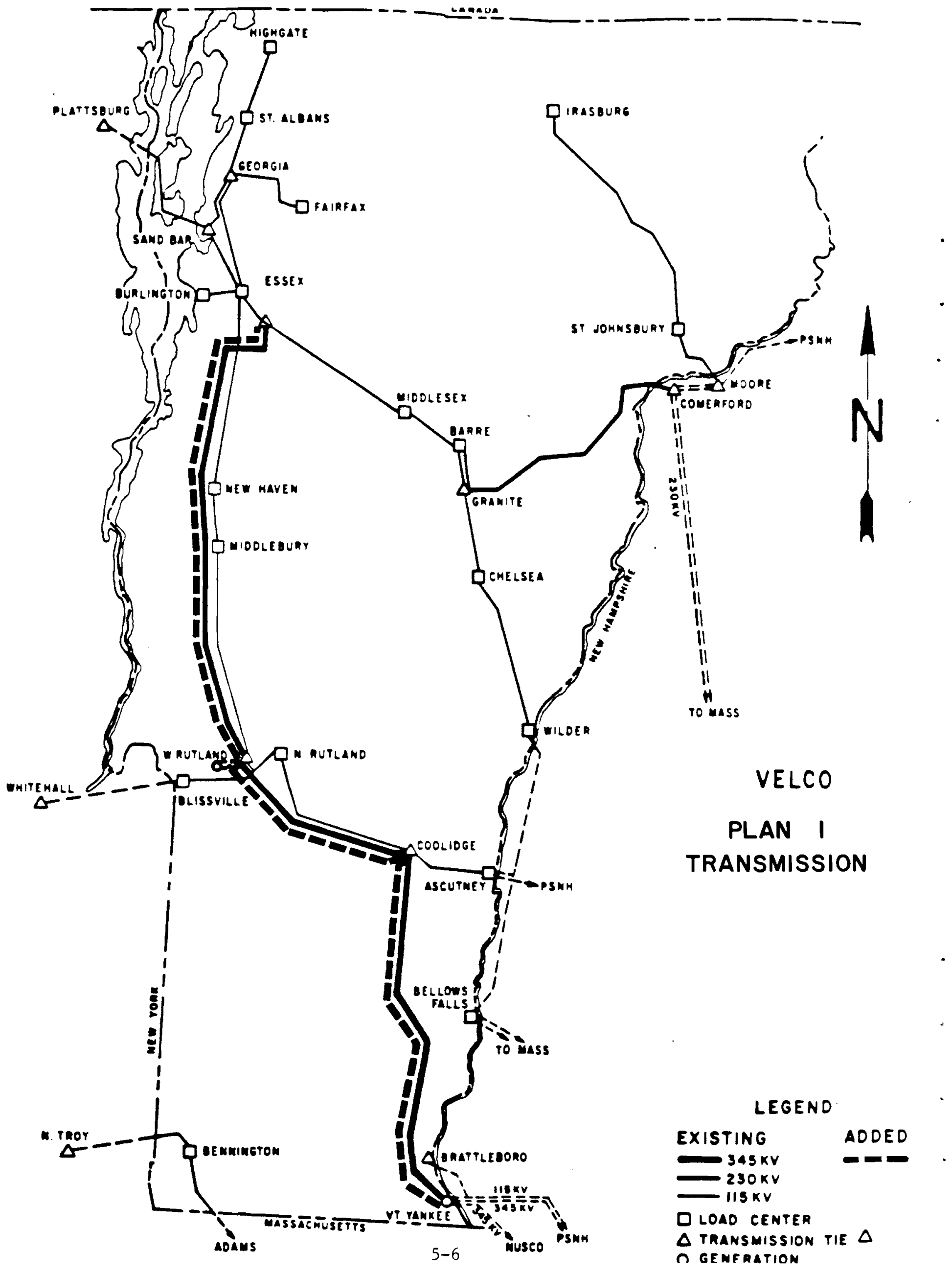




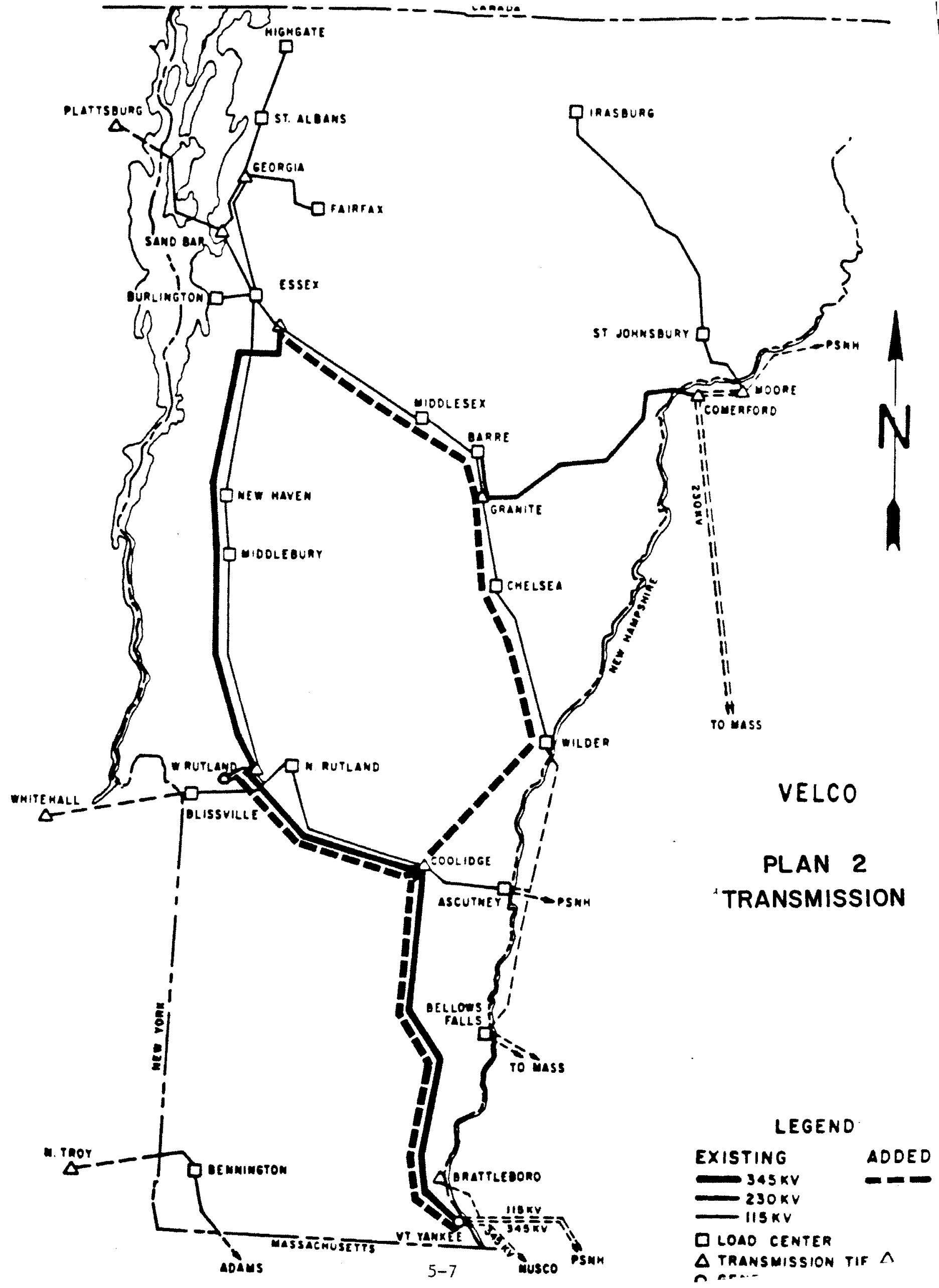




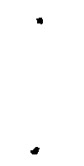

•

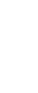


SECTION 6. - CONSTRUCTION PROCEDURES 
CONSTRUCTION PROCEDURES

Interest charged on money funded for construction can be substantial on an extended construction program. Because of its complexity, an underground pumped storage project will normally require a longer construction period than a conventional above ground facility. It is therefore important that the method of approach be carefully examined to shorten construction time to reasonable limits. To achieve this goal, at least three shafts should be excavated simultaneous $1 y$.

\section{$6.1 \quad$ Scheme 1}

In Scheme 1, the underground excavation work is attacked from two directions, one from the intake shaft at Elevation 1400 and the other from the quarry site area at Elevation 495 in the powerplant area. The major rock holsting equipment must be installed in the Intake shaft since most of the spoil from the underground excavation is intended for use in the construction of the upper reservolr dike. When the intake shaft is completed, the sinking hoist is removed and erected at the vent shaft location. Before the work of excavating the power tunnel can begin the intake shaft must be equipped with a double 30 ton skip hoist, a personnel holst and ventilation ducts for the excavation. When the water tunnel has been completed beyond the intersection of the east transverse tunnel and the drift from that tunnel to the water tunnel has been finished, the personnel hoist will be removed from the intake shaft and replaced by a twin 30 ton skip holst which duplicates the one already 1nstalled. Personnel access is then transferred to the heavy holst shaft.

The heavy hoist shaft is sunk simultaneously with the intake shaft but is approximately 1,000 feet shorter. As in the alternate scheme, the heavy hoist shaft contalns a skip holst, personnel hoist and a construction ventilation system. As 1t is sunk, the shaft is temporarily stopped at the transformer gallery until a drift is excavated to the vicinity of the high voltage cable shaft. When it is completed, shaft sinking continues to the elevation of the powerplant crown, at which point sinking is stopped until a construction adit is excavated for the full length of the powerplant cavern. Upon the adit's completion, the shaft is continued to its ultimate depth, and replaced by a construction skip holst. The personnel holst remains in operation. 
From the bottom of the shaft, a drift is constructed to the end of the draft tube collector tunnel, and the collector tunnel driven to the intersection of the east transverse tunnel. The draft tube tunnels are excavated from the collector tunnel to a point beyond the centerline of units in the powerplant as soon as the headings are exposed in the collector tunnel. When completed, down drilled, raise bored mucking shafts are completed to the powerplant construction drift. All powerhouse excavation is moved to these shafts and removal is done through the draft tube tunnels.

A north and south heading is established when the collector tunnel intersects the east transverse tunnel. The south heading continues to the intersection of the water tunnel, which should be completed beyond that point at the time, as shown on the schedule. As previously described, personnel access is then transferred to the heavy hoist shaft from the intake shaft. All excavated rock at this time is then routed through the water condult to the intake shaft.

To expedite the excavation of the reservolr tunnels, flve separate headings are driven simultaneously. All excavation of the reservolr tunnels should be done from east to west to keep any water which may occur from building up at the headings, because the tunnels are constructed on a slope of $+2 \%$ from east to west.

Once the first tunnel is completed, work begins on the west transverse tunnel. As it intersects the ventilation shaft, more ventilation for the groundwater excavation is avallable. The high voltage cable shaft is sunk to the level of the transformer gallery. After completion, the sinking equipment is removed and the skip hoist in the heavy hoist shaft removed and erected in this shaft. This will allow erection of the permanent heavy holst machinery and platform to begin. A11 excavated rock from the construction of the transformer and gate galleries and the drainage gallery is removed through the cable shaft. Gate slots are down drilled, ralsed and expanded to the level of the roof of the draft tube tunnels. Rock is removed from the bottom and transported to the intake shaft.

\section{$6.2 \quad$ Scheme 2}

In Scheme 2, the shafts considered are the heavy hoist shaft, used to transport personnel and equipment and provide ventilation for the underground excavation, 
the personnel shaft for transportation of personnel and a rock hoisting shaft, dedicated solely to removal of the excavated rock from the reservoir caverns and powerplant. During the mobilization of the hoisting equipment for these shafts, buildings in the upper reservolr area should be razed, top soll removed and stockpiled and the dike foundation area prepared for placement of the embankment fi11.

The heavy hoist shaft is sunk simultaneously with the rock hoisting shaft. The heavy hoist shaft contains the initial personnel hoist and the construction ventilation system. As it is sunk, the shaft is temporarily stopped at the transformer gallery until a drift is excavated to the vicinity of the high voltage cable shaft. When it is completed, shaft sinking continues to the elevation of the powerplant crown, at which point sinking is stopped until a construction adit is excavated for the full length of the powerplant cavern. Upon the adit completion, the shaft continues to its ultimate depth, the sinking hoist removed, erected at the high voltage shaft, and the construction personnel elevator installed.

From the bottom of the shaft, a drift is constructed to the end of the draft tube collector tunnel just west of the rock hoisting shaft. The rock hoisting shaft which is completed at approximately the same time as the heavy hoist shaft is the main source for removal of the excavated rock from the reservoir cavern. When the rock hoisting shaft reaches its bottom at the invert of the collector tunnel, the sinking shaft is removed and erected at the personnel shaft. A double counterbalanced rock hoisting skip of 30 tons capacity each is then erected in the shaft and rock removal can begin. Construction personnel are transported to the work through the heavy hoist shaft initially. The collector tunnel is then driven to the intersection of the east transverse tunnel. The draft tube tunnels are excavated from the collector tunnel to a point beyond the centerline of units in the powerplant as soon as the headings are exposed in the collector tunnel. When completed, down drilled, raise bored mucking shafts are completed to the powerplant construction drift. All powerplant excavation is moved to these shafts and removal of the excavated rock is done through the draft tube tunnels. When excavation for the draft tube collector tunnel reaches the lower reservoir east transverse tunnel, three tunnel headings w111 be established, one each in the north-south direction and one on the west heading along the middle east-west tunnel of the lower reservolr. The tunnel will be driven until it reaches the 
west transverse tunnel. From this polnt the west transverse tunnel is driven toward the south unt1l it Intersects the vent shaft. When the vent shaft reaches the elevation of the west transverse tunnel a double skip holst is installed in the vent shaft of the same capacity as that in the rock holsting shaft.

Five separate headings are driven simultaneously at the reservolr tunnels from east to west on a slope of $+2 \%$. To malntaln a mucking schedule that keeps pace with this amount of excavation both the rock holsting shaft and the vent shaft holsts must be used. Rock materlal excavated and removed from the rock hoisting shaft and vent shaft will be deposited in the swampland on either side of the Castleton River.

Concrete for the plant is carried to the elevation of the lower reservoir mixed dry. A small mixing plant is erected in one of the completed reservolr tunnels and water added to it at that point. Because of the extremely high head, water is not piped to that elevation but is delivered in trailer tanks of $10,000 \mathrm{gpm}$ capacity. 


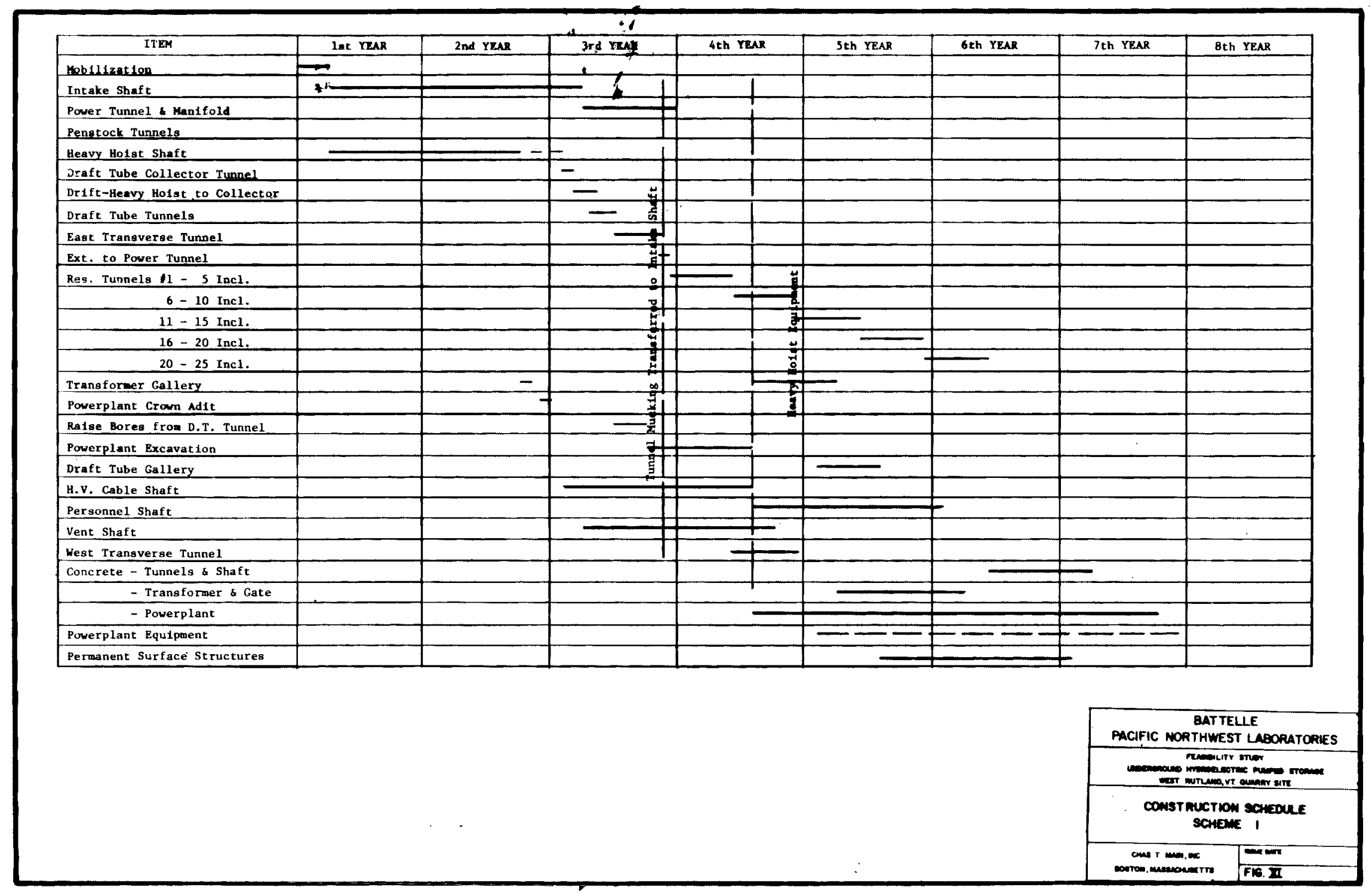




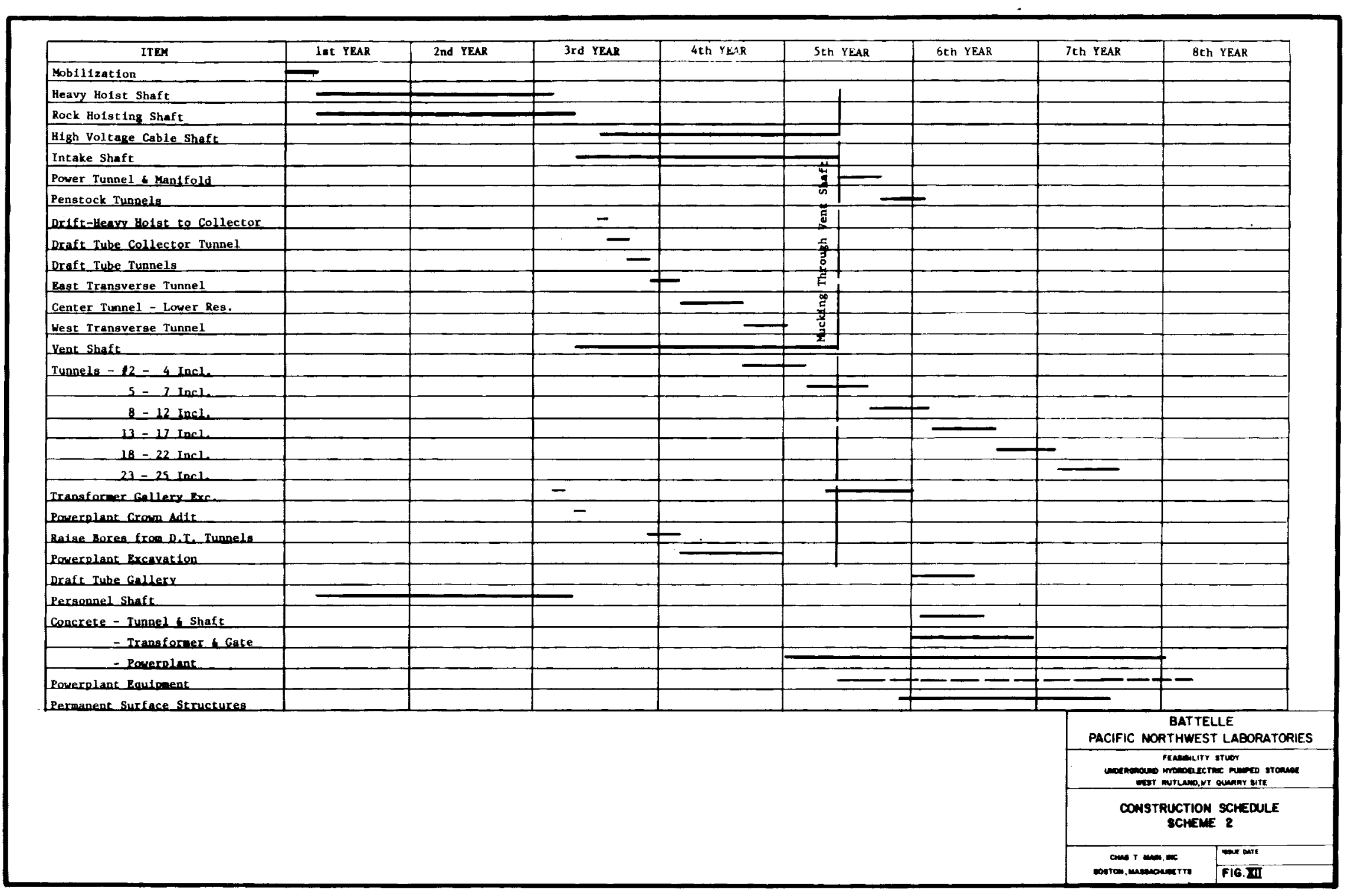


SECTION 7 - ESTIMATES 


\section{$7.1 \quad \underline{B a s i s}$}

Several sources were used in the preparation of the profect estimates for the prefeasibility study. For those site specific items of excavation, concrete, rock bolts and shotcrete support, quantity takeoffs were made, unit prices derived and the product of the two entered in the direct cost column. These items include, the reservolrs, both surface and underground. The underground powerplant, transformer and gate galleries and the water tunnels and penstocks.

Costs common to any powerplant of simflar capacity whether above ground or underground, were taken from previous projects and escalated to January 1982 pricing. Items covered by this phase include such items as fire protection, auxilliary mechanical systems, turbine unwatering systems, accessory electrical equipment and the switchyard structures and improvements.

Major 1tems of equipment, such as turbines and generators were obtalned by adjusting for head, output and speed costs given in the Argonne Laboratory Report on two stage pump-turbines.

Cost of station equipment, including transformers and clrcult breakers were profected from previous projects and escalated to January 1982 price levels.

Shaft excavation and support and costs of holsting equipment were obtalned from previous EPRI studies and an "Evaluation of the Concept for Underground Pumped Storage", updated, verifled and escalated to January 1982 pricing. Since al1 the shafts with the exception of the reservolr vent shaft are associated with the powerplant, costs for these 1tems are included under structures and improvements, with the powerplant.

The summation of the costs for these items comprise the estimated direct cost. At this stage of the investigation a number of unknowns are apparent, the cost of which cannot be readily quantifled. To provide some degree of confidence in the order of magnitude costs obtained, a contingency of $25 \%$ was added to the 
direct costs for all underground work. 15\% was added for all other items. To this subtotal, costs of engineering and overhead were added, to arrive at a total estimated cost. With the exception of transmission, costs derived covered all project features up to the transmission terminal at the end of the switchyard.

In Scheme 2 reduction in cost was recognized for the sale of marketable marble and the sale of industrial land created by the deposition of spoil in the swampland. 
FERC

ACCOUNT NO.

ITEM

TOTAL COST

331

332

$-2$

$-8$

$-12$

333

$-2$

$-5$

$-8$

$-9$

$-11$

$-13$

334

335

Structures and Improvements

Powerplant

Heavy Holst Shaft

$59,137,000$

$17,310,000$

Personnel Shaft

$9,868,000$

Vent Shaft

High Voltage Cable Shaft

Rock Holsting Shaft

$8,946,000$

$14,420,000$

Reservoirs, Dams \& Waterways

Reservoir Clearing

Power Intake

Power Tunnels

Penstocks

Ta11race Tunnels

Upper Reservolr

Lower Reservoir

$$
\begin{array}{r}
54,000 \\
1,679,000 \\
51,495,000 \\
5,490,000 \\
4,561,000 \\
31,307,000 \\
248,186,000
\end{array}
$$

Waterwhee1s, Tunnels \& Generators

Fire Protection

Motor-Generators

Spherical Valves

Turbines \& Accessories

Auxillary Systems

Spiral Case \& Draft Tube Unwatering Systems

300,000

$26,700,000$

$6,800,000$

$30,000,000$

348,000

800,000

Accessory Electrical Equipment

$10,362,000$

Miscellaneous Powerplant Equipment

$3,281,000$

118,000

Roads, Ra11roads \& Bridges

$1,100,000$

Sw1tchyard-Structures \& Improvements

$11,067,000$

Station Equipment
Total D1rect Cost
Contingencies
Subtotal
Engineering
Overhead
Total Estimated Cost

$\frac{11,067,000}{543,329,000}$

$123,613,000$

$666,942,000$

$40,058,000$

$\frac{6,665,000}{713,665,000}$

Cost per KW $\frac{713,665,000}{1,200,000}=595$ 
FERC

ACCOUNT NO.

ITEM

TOTAL COST

331

Structures and Improvements

Powerplant

Heavy Hoist Shaft

Personne1 Shaft

Vent Shaft

High Voltage Cable Shaft

$59,137,000$

$17,310,000$

$9,868,000$

$8,946,000$

$14,420,000$

332

$-2$

$-8$

$-12$

$-13$

Reservolrs, Dams \& Waterways

Reservoir Clearing

Powe $r$ Intake

Power Tunnels

Penstocks

Tailrace

Upper Reservoir

Lower Reservoir

42,000

$1,679,000$

$51,495,000$

$5,490,000$

$4,561,000$

$24,106,000$

$189,195,000$

333

$-2$

$-5$

Waterwhee1s, Turbines \& Generators

F1re Protection

Motor-Generators

Spherical Valves

Turbines \& Accessories

$-9$

$-11$

$-13$

Auxi111ary Systems

Spiral Case \& Draft Tube Unwatering System

Accessory Electrical Equipment

300,000

$26,700,000$

$6,800,000$

$30,000,000$

348,000

800,000

$10,362,000$

Miscellaneous Power Plant Equipment

$3,281,000$

Roads, Railroads and Bridges

118,000

Switchyard - Structures \& Improvements

$1,100,000$

353

Station Equipment

Tota1 Direct Cost
Contingencies
Subtotal
Engineering
Overhead
Tota1 Estimated Cost
Ex. Transmission \& IDC

$11,067,000$

$4 \overline{77,125,000}$

$107,778,000$

$584,903,000$

$35,094,000$

$\frac{5,849,000}{625,846,000}$

Ex. Transmission \& IDC

$\frac{5,849,000}{625,846,000}$

Cost per KW $\frac{625,846,000}{1,200,000}=\$ 521$ 
FERC

ACCOUNT NO.

ITEM

TOTAL COST

331

Structures \& Improvements

Powerplant

Heavy Holst Shaft

$59,137,000$

$17,310,000$

Personnel Shaft

$9,868,000$

Vent Shaft

High Voltage Cable Shaft

$8,946,000$

$14,420,000$

332

Reservolrs, Dams \& Waterways

Reservolr Clearing

Power Intake

Power Tunnels

Penstocks

Ta11race Tunnels

Upper Reservolr

Lower Reservolr

$$
\begin{array}{r}
34,000 \\
1,679,000 \\
51,495,000 \\
5,490,000 \\
4,561,000 \\
19,445,000 \\
153,144,000
\end{array}
$$

333

Wate rwhee1s, Turbines \& Generators

Fire Protection

Motor-Generators

Spherical Valves

Turbines \& Accessories

Auxillary Systems

Spiral Case \& Draft Tube Unwatering System

Accessory Electrical Equipment

300,000

$26,700,000$

$6,800,000$

$30,000,000$

348,000

800,000

$10,362,000$

335

Miscellaneous Powerplant Equipment

$3,281,000$

118,000

Roads, Ra1lroads \& Bridges

$1,100,000$

352

Switchyard

Station Equipment
Total Direct Cots Contingencies

Subtotal

Engineering Overhead

Total Estimated Cost

Ex. Transmission \& IDC

$11,067,000$

$436,405,000$

$\frac{98,059,000}{534,464,000}$

$32,067,000$

$\frac{5,346,000}{571,877,000}$

Cost per KW $\frac{571,877,000}{1,200,000}=\$ 476$ 
FERC

ACCOUNT NO.

ITEM

TOTAL COST

331

Structures \& Improvements

Powerplant

Heavy Hoist Shaft

Personnel Shaft

Vent Shaft

High Voltage Cable Shaft

Rock Holsting Shaft

$59,137,000$

$36,656,000$

$13,003,000$

$11,879,000$

$12,419,000$

$28,529,000$

332

$-2$

$-8$

Reservolrs, Dams \& Waterways

Reservolr Clearing

76,000

Power Intakes

Power Tunnels

Penstocks

Tailrace Tunnels

Upper Reservolr

Lowe $\mathbf{r}$ Reservolr

$1,679,000$

$19,433,000$

$5,491,000$

$4,561,000$

$19,187,000$

$248,187,000$

333

Waterwheels, Turbines \& Generators

F1re Protection

Motor-Generator

Spherical Valves

Turbines \& Accessories

Auxilliary Systems

Spiral Case \& Draft Tube Unwatering Systems

300,000

$26,700,000$

$6,800,000$

$-9$

$-11$

$-13$

Accessory Electrical Equipment

$30,000,000$

348,000

800,000

$10,362,000$

Miscellaneous Power Plant Equipment

$3,281,000$

200,000

Roads, Rallroads \& Bridges

$1,100,000$

352

Switchyard-Structures \& Improvements

$11,067,000$

Station Equiprent
Total Direct Cost Contingencies
Subtotal
Engineering
Overhead

Total Estimated Cost $\frac{11,067,000}{551,195,000}$

$126,763,000$

$677,958,000$

$40,677,000$

$\frac{6,779,000}{725,414,000}$

\begin{tabular}{l}
$725,414,000$ \\
Savings $\quad \begin{array}{r}-28,821,000 \\
\hline\end{array}$ \\
\hline
\end{tabular} 
FERC

ACCOUNT NO.

331

Structures \& Improvements

Powerplant

Heavy Holst Shaft

Personnel Shaft

Vent Shaft

High Voltage Cable Shaft

Rock Holsting Shaft

$59,137,000$

$36,656,000$

$13,003,000$

$11,879,000$

$12,419,000$

$28,529,000$

332

Reservoirs, Dams \& Waterways

Reservolr Clearing

58,000

Power Intake

Power Tunnels

Penstocks

Tallrace Tunnels

Upper Reservolrs

Lowe $r$ Reservolrs

$1,679,000$

$19,433,000$

$5,491,000$

$4,561,000$

$14,776,000$

$189,195,000$

333

$-2$

$-5$

$-8$

$-9$

$-11$

$-13$

Waterwheels, Turbines \& Generators

Fire Protection

Motor-Generators

Spherical Valves

Turbines \& Accessories

Auxilliary Systems

Spiral Case \& Draft Tube Unwatering Systems

Accessroy Electrical Equipment

300,000

$26,700,000$

$6,800,000$

$30,000,000$

348,000

800,000

$10,362,000$

335

Miscellaneous Powerplant Equipment

$3,281,000$

Roads, Rallroads \& Bridges

200,000

352

Switchyard-Structures \& Improvements

$1,100,000$

353

Station Equipment

$$
\begin{aligned}
& \text { Total Direct Cost } \\
& \text { Contingencies } \\
& \text { Subtotal } \\
& \text { Engineering } \\
& \text { Overhead } \\
& \text { Total Estimated Cost }
\end{aligned}
$$

$\frac{11,067,000}{487,774,000}$

$111,335,000$

$599,109,000$

$35,946,000$

$5,991,000$

$641,046,000$

Savings $\quad-21,631,000$

$619,415,000$

$$
1,200,000=\$ 516 / \mathrm{kW}
$$


FERC

ACCOUNT NO.

ITEM

TOTAL COST

331

Structures and Improvements

Powerplant

Heavy Holst Shaft

Personne1 Shaft

Vent Shaft

H1gh Voltage Cable Shaft

Rock Hoisting Shaft

$59,137,000$

$36,656,000$

$13,003,000$

$11,879,000$

$12,419,000$

$28,529,000$

332

$-2$

$-8$

$-12$

$-13$

Reservo1rs, Dams \& Waterways

Reservoir Clearing

47,000

Power Intake

Power Tunnels

Penstocks

Tallrace Tunnels

Upper Reservolr

Lower Reservolr

$1,679,000$

$19,433,000$

$5,491,000$

$4,561,000$

$11,900,000$

$153,144,000$

333

$-2$

$-5$

$-8$

$-9$

$-11$

$-13$

Waterwheels, Tunnels \& Generators

Fire Protection

Motor-Generators

Spherical Valves

Turbines \& Accessories

Auxillary Systems

Spiral Case \& Draft Tube Unwatering Systems

Accessory Electrical Equipment

300,000

$26,700,000$

$6,800,000$

$30,000,000$

348,000

800,000

$10,362,000$

335

Miscellaneous Powerplant Equipment

$3,281,000$

Roads, Railroads \& Bridges

200,000

352

Switchyard-Structures \& Imp rovements

$1,100,000$

353

Station Equipment
Total Direct Cost Contingencies
Subtotal
Engineering
Overhead
Tota1 Estimated Cost

$\frac{11,067,000}{448,836,000}$

$101,917,000$

$550,753,000$

$33,045,000$

$5,507,000$

$\frac{5,507,000}{589,305,000}$ 
SECTION 8. - SYSTEM STUDY ECONOMICS 
SYSTEM STUDY ECONOMICS

The amount of savings a pumping unit can achieve is a function of the amount and type of each fuel being displaced as well as the type of fuel utilized for the pumping.

Including the base case, five cases were run in the first effort, with two additional runs made after the results of the original cases were reviewed. of the four cases run in which the pumped storage project was added, Case 2 where the $1200 \mathrm{MW}$ pumping unit was added in 1996 allowing the system excess capacity throughout most of the study is the one which allows the highest capital cost $(\$ 400)$ to be expended on the project and still remain as economical as the base case. The principle reason for such a low capital cost lies in the fact that New England already has pumping units which utflize the avallable base load generation and st111 do not operate at maximum capacity.

The results of the studies produced Figure 8-1 which shows the maximum capacity factor achieved by additional pumped storage units as a function of the amount of coal and nuclear generation on the system. If an assumption is made that the pumper receives its energy from a coal unit (without scrubbers) and displaces low sulfur $\# 6$ o11, Figure 8-2 may be drawn which indicates the capacity factor an uncommitted unit must have in order to pay for itself by the year 2013. Using these charts enables one to determine the base load generation necessary to economically add a pumping unit with a particular capital cost.

As an example, assume a total installed cost of a pumped storage plant, including AFUDC, of $\$ 500 / \mathrm{KW}$ in 1980 dollars. The cost/benefit analysis of Figure 8-2 shows that this plant must operate at about a $15 \%$ annual capacity factor in order to have the present worth of production cost savings offset the present worth of capital costs over a 20-year period. In deriving Figure 8-2, the benefits are those obtained by using the pumped storage plant to displace low sulfur $\#^{6}$ of1 at an assumed 1994 price of $\$ 21.30 /$ MBU with coal at an assumed 1994 price of $\$ 7.38 / \mathrm{MBTU}$. 
Figure 8-1 is based on results of cases run for this study. For an additional pumped storage plant on the New England system beyond Bear Swamp and Northfield Mountain, Figure 8-1 indicates that the nuclear and coal capacity must be at least $66 \%$ to $67 \%$ of peak load for this additional pumped storage unit to achieve - an annual capacity factor of $15 \%$. Table 1 in the appendix summarizes the coal and nuclear generation as a percent of peak load for the various cases studied. Even for the most optimistic expansion case, a nuclear/coal mix of 66 to $67 \%$ is not achieved unt11 the $2000 / 2001$ power year.

Based on this example and the estimated cost (500-600 \$/KW) of the proposed Vermont Underground Pumped Storage Project, it would appear that the project is not economically feasible before 2000 and then only if a coal/nuclear generation mix of 66 to $67 \%$ can be achieved.

However, since the expected life of a pumped storage plant is 50 to 60 years and production savings may accrue beyond the 20 years cited in the above example, it may be possible to justify the unit at a lower capacity factor and hence at a lower percentage of base load generation. Figure 8-2 also shows the break even capital costs for the present worth of capital costs and production savings to eternity. Again for this curve, the benefits are the production savings obtained by using the pumped storage plant to displace low sulfur \#6 oil with coa1. For the same $\$ 500 / \mathrm{KW}$ total plant cost, this curve shows that the plant must operate at an annual capacity factor of 8 to $9 \%$ to break even when the fuel savings are taken to eternity. From Figure 8-1, a new unit would be expected to operate at this capacity factor whenever the coal and nuclear generation is above $55 \%$ of peak load. Table 1 shows this would be achieved as long as the coal and nuclear generation $\mathrm{mix}$ can be maintained at a level just slightly more than that attained after the addition of the current pool planned units.

Under the conditions of this latter example, the projected costs of the Vermont Underground Pumped Storage Project may be economically feasible in the 1990's. 
However, the project developers must assess the validity of the assumption that the pumped storage project will be displacing oil (or any fuel of comparable cost) after 2013. Such consideration should recognize that at some point the existing New England oil units will be retired. Also, due to scarcity, oil may not be allowed as an electric utility boller fuel at some time in the future. At the current time, conventional coal and nuclear units are the most economic choice for displacement of o1l. The pumped storage unit added in the 1990s may continue to operate economically in conjunction with these base load units after 2013 at a capacity factor above $8 \%$ to displace such alternatives as coal gasification.

No capacity credits are assumed in the development of Figure 8-2 and the examples presented above. Only the prospective owners of the project can assign a capacity credit based on the value of the capacity to their systems relative to the other available alternatives. From the standpoint of the New England system, coal and nuclear units appear to be the most economical generation choice in the 1990s. If for any reason it is not feasible for vermont to install or buy into coal or nuclear units, the pumped storage unit may deserve a capacity credit which has not been reflected. This may increase the attractiveness of the project at relatively low capacity factors and enhance the findings of the above examples.

Ideally, an optimal expansion plan for the New England Power Pool could be developed excluding the Vermont Project and the costs tested for the Vermont Pumped Storage Porject being installed either in place of specific plants contained in the plan or at various in service dates on top of the plan. Nelther time nor funds was available for such an expanded analysis for the prefeasibility study. As a partial solution, two additional cases were run after reviewing the results obtained from the original four cases. The first, called base case $\# 2$ attempted to develop for the New England System an expansion program using only coal fired and nuclear units. The second case, case \#5, Imposed the Vermont pumped storage plant on top of this sequence in 1996, the earliest reasonable in service date. 


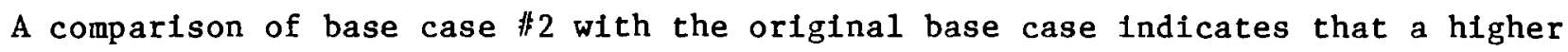
installed capacity will result for the same degree of reliability, because of the higher forced outage rating associated with the type of generation employed in this sequence. Even so, the overall cost of this scenario is less than the original base case. This is consistent with NEPLAN's observation that coal and nuclear units are probably the most economic mix for future development.

Case \#5 describes only the production cost savings of the Vermont pumped storage plant if it is installed in 1996 on top of the base case \#2 plan. The savings are the largest of any case studies made and would permit a plant cost of about $\$ 442$ at 1982 pricing levels. This value is significantly less than the estimated cost of the proposed pumped storage plant and it remains uneconomic. 


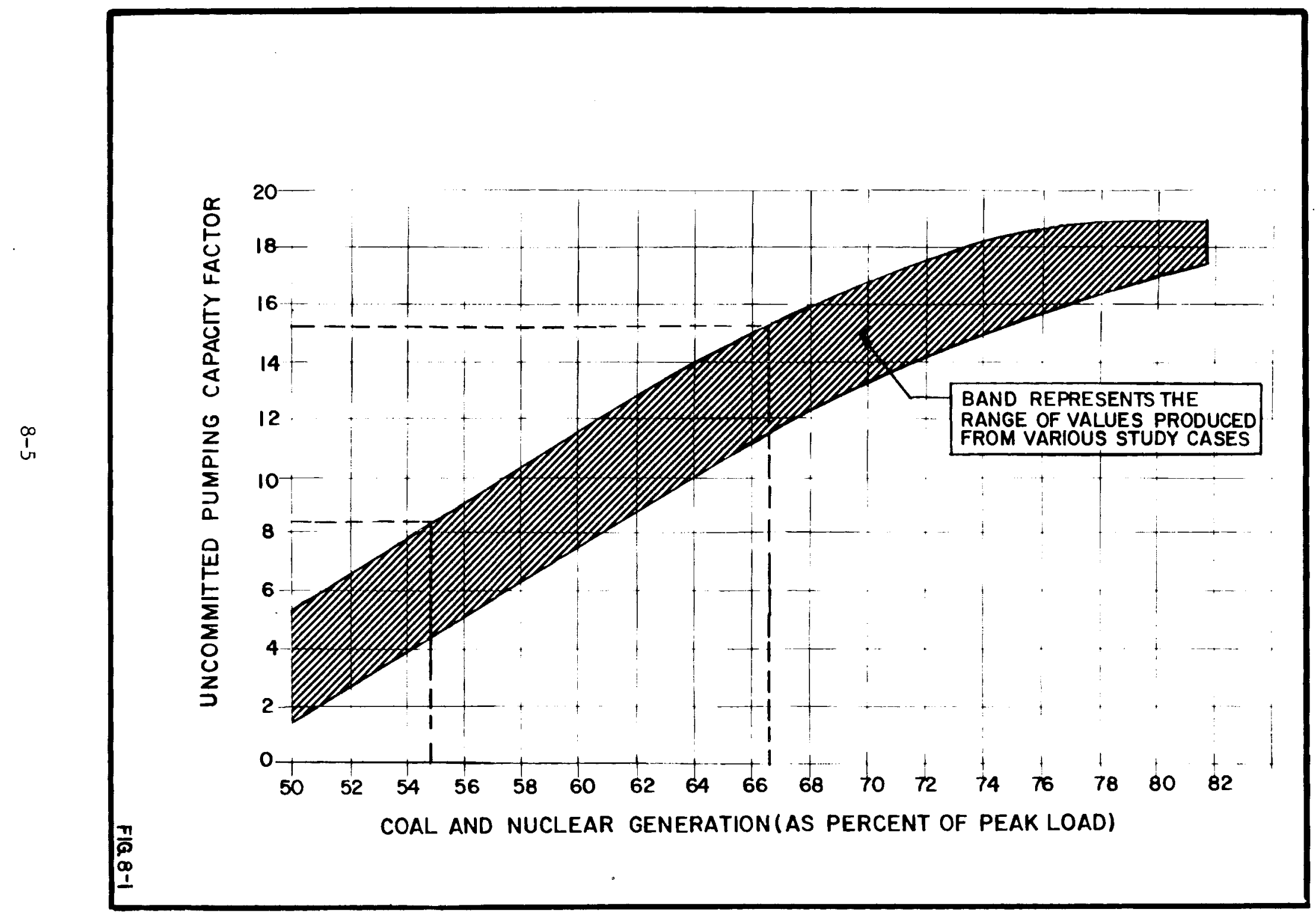




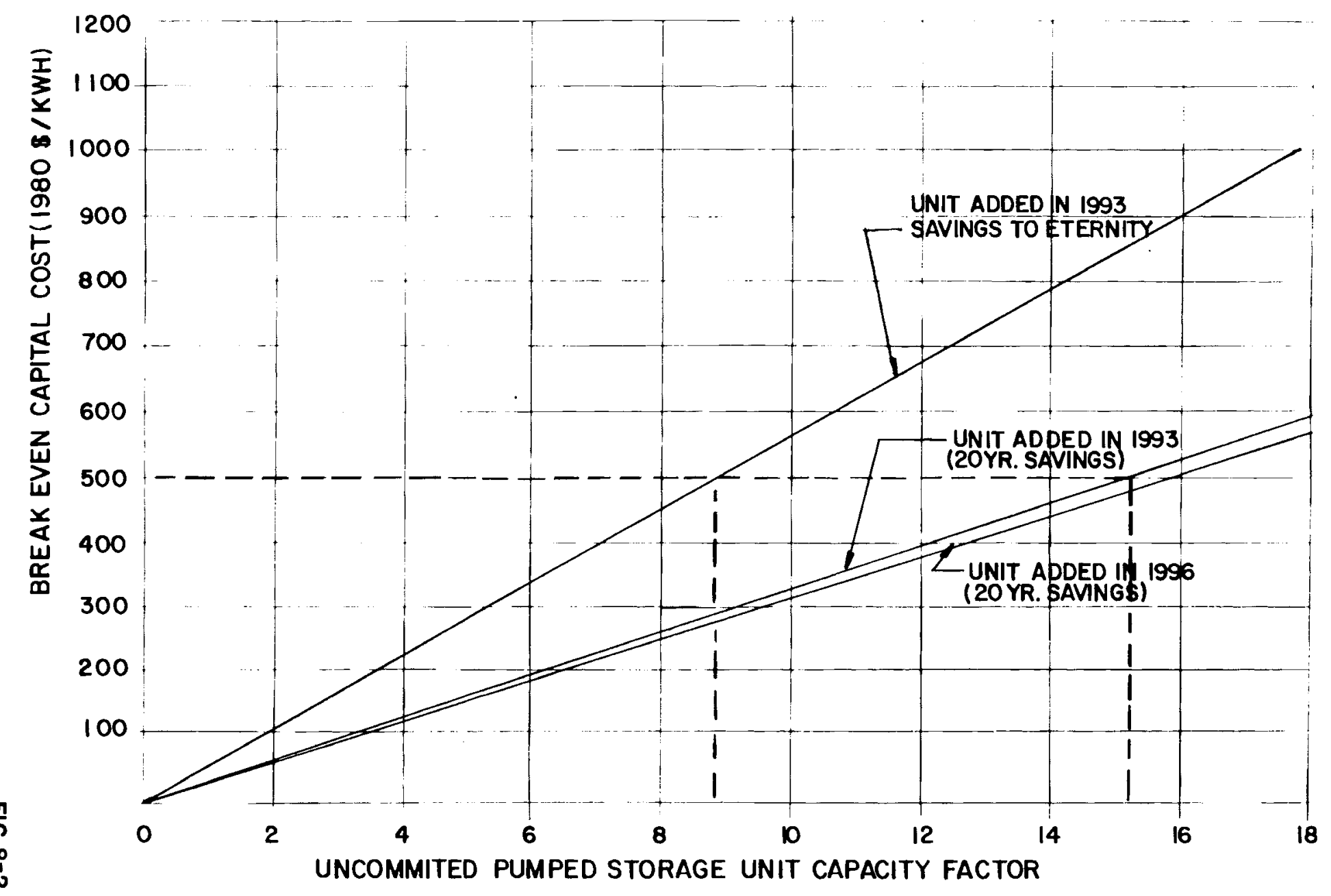


SECTION 9. - CONCLUSIONS AND RECOMMENDATIONS 


\section{$9.1 \quad$ Engineering}

From an engineering and geologic aspect, given the present knowledge of the state of the art and the geologic condition as known, construction of the West Rutland underground pumped storage is feasible. The conservative cost estimate prepared indicates that the cost is comparable to similar conventional projects for this type of peak generation. The major cost affecting an underground plant at this depth is the cost of interest during construction because 1 will require two to three years more than a conventional plant.

Several features unique to an underground pumped storage plant must however be considered. Because of 1 ts depth and resultant increase in temperature, the efficlency of the construction work force may be slightly lower than in a conventional plant constructed at the surface. No adjustment has been made in the unft prices for this occurrence. In the winter months when ambient temperatures at the surface are below freezing, exposure of the warmer water from the underground lower reservoir may cause some environmental problems. The effect of this condition has not been completely evaluated but must be considered if future studies appear warrented.

\section{$9.2 \quad \underline{E c o n o m i c s}$}

For the assumptions used in the five New England Power Planning cases investigated and the two additional computer runs made later, the West Rutland Underground Pumped Storage Project appears uneconomic. There are however several variables that could affect these findings, but to thoroughly investigate these additional cases, funding beyond the prefeasibility level must become available. For the most optlmistlc case, the breakeven point on an energy savings base allows a capital cost investment of $\$ 442$ per k1lowat at 1982 pricing levels. This figure includes capital costs, engineering, overhead and interest during construction. 
In their planning, the New England Power Pool expansion sequences used in the studies added the third pumped storage project on a peak daily load curve under the 600 MW Bear Swamp Project with a $71 \%$ efficiency and the Northfield Mountain Project with an efficiency of $74 \%$. The estimated efficiency of the proposed West Rutland Project is $75 \%$. If the most efficient units were scheduled first, to minimize production costs, it would appear that the West Rutland project should be scheduled further up the peak, thus reducing the required amount of storage and the resultant capital costs. To assess the effect of such a scenario, 8 hour and 10 hour storage costs were prepared for a comparison with the most optimistic investment value derived in the studies. The costs, however, do not include interest during construction although all other items are recognized. In Scheme II, savings due to sale of marketable products and reclamation of land are included. As can be seen from the following table all costs are higher than the breakeven limit set by the most optimistic evaluation $1 . e . \$ 442 / \mathrm{KW}$.

\begin{tabular}{cccc} 
Storage & Capacity & Scheme I & Scheme II \\
\cline { 2 - 3 } 12 & $1200 \mathrm{MW}$ & 595 & 581 \\
10 & $1200 \mathrm{MW}$ & 521 & 516 \\
8 & $1200 \mathrm{MW}$ & 476 & 476
\end{tabular}

It must therefore be concluded that the West Rutland Project is uneconomic at this time under the present considered conditions on the New England Power System from the information derived in the studies. To accomodate the plant with pumping energy from a nuclear and coal generation mix in the amount required to support the project, 55 to $65 \%$ of the base load must be provided in this form before the project could become feasible. This condition is projected to occur in the year 2000 or beyond. Several variables should be examined periodically, however, because they could materially affect the present findings. These are:

- The future cost differential between ofl and coal;

o The capacity benefit of the West Rutland underground pumped storage plant;

o The system's ability to increase imports from Hydro Quebec;

- Larger load growth than anticipated. 


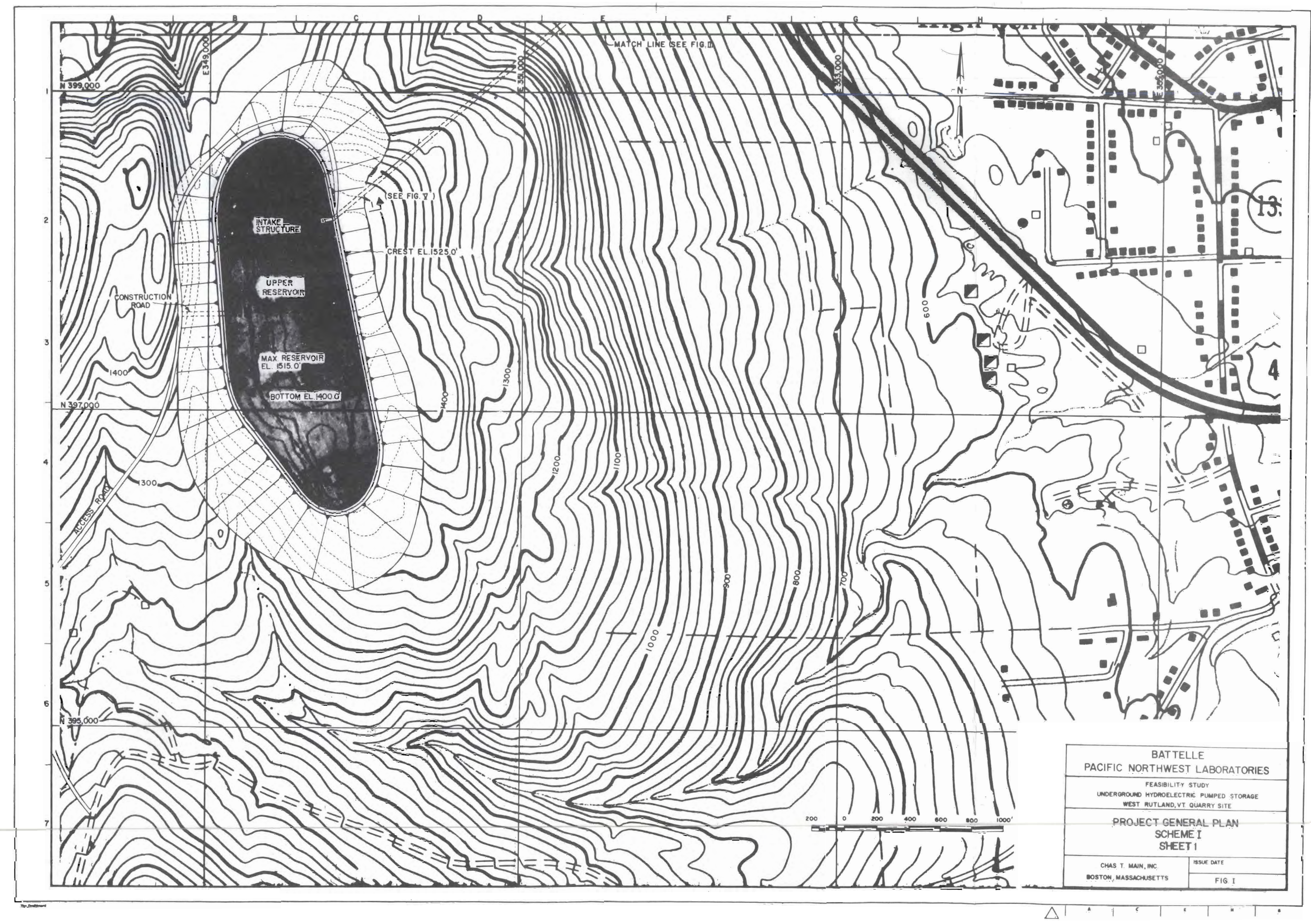





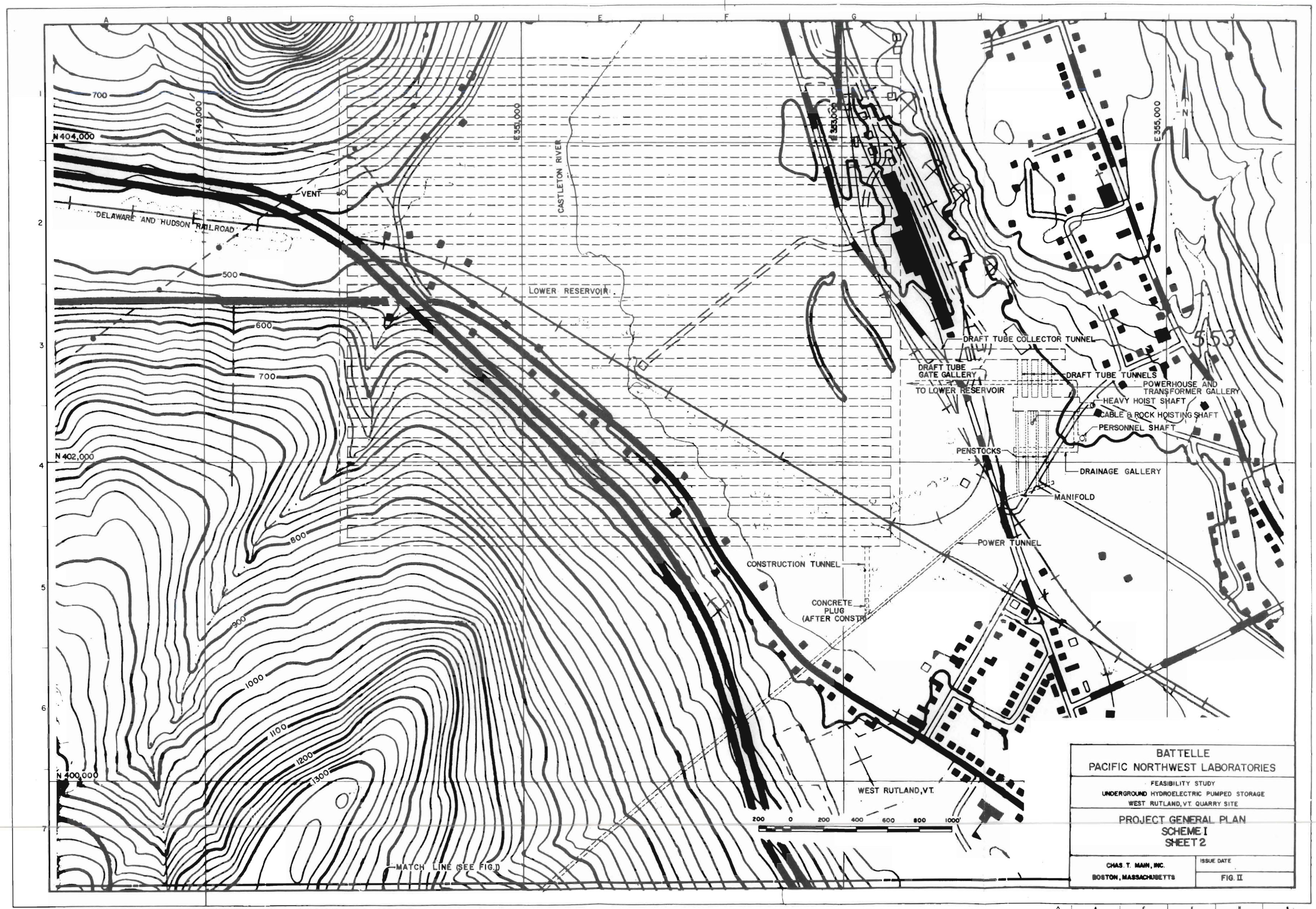





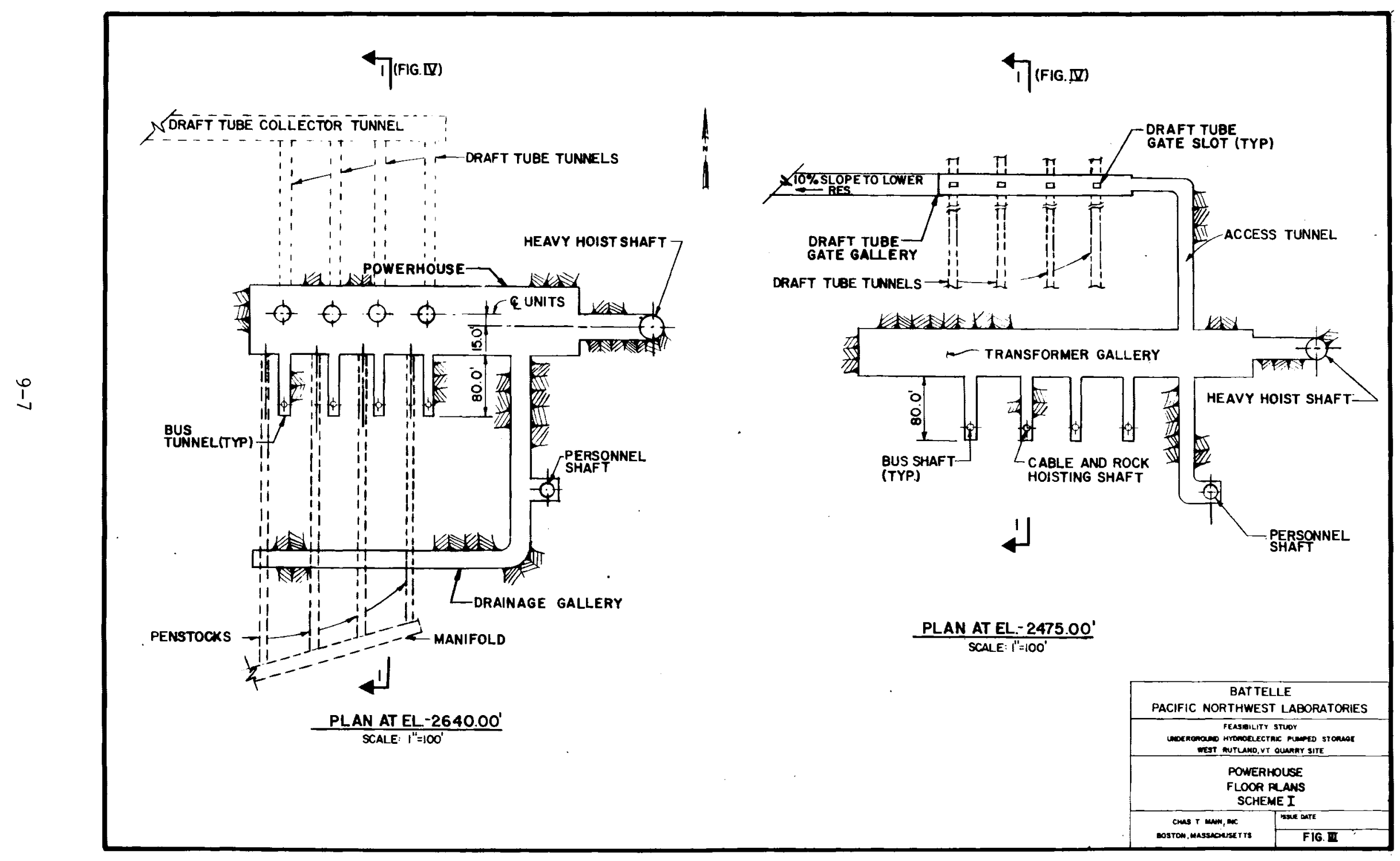




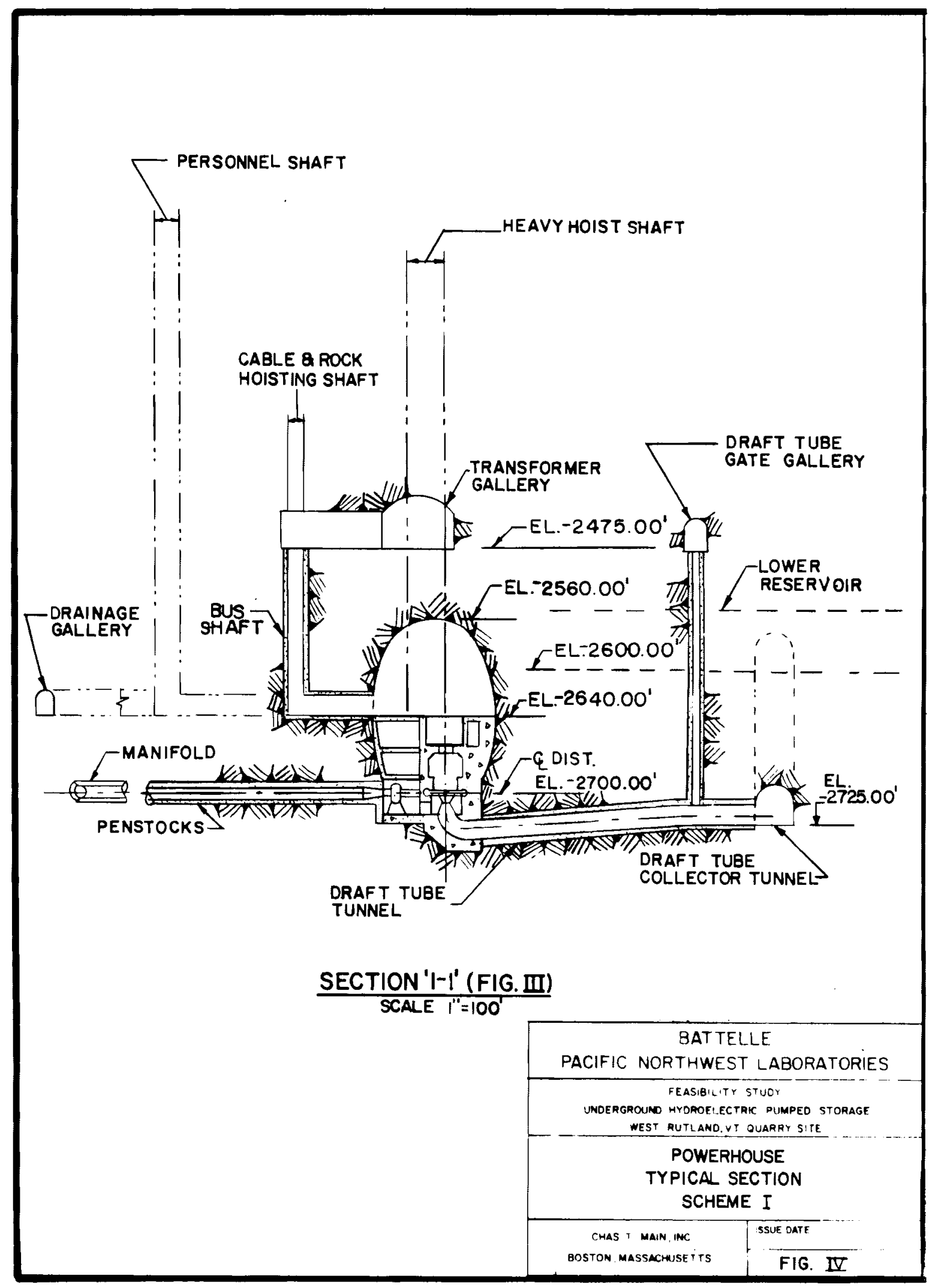




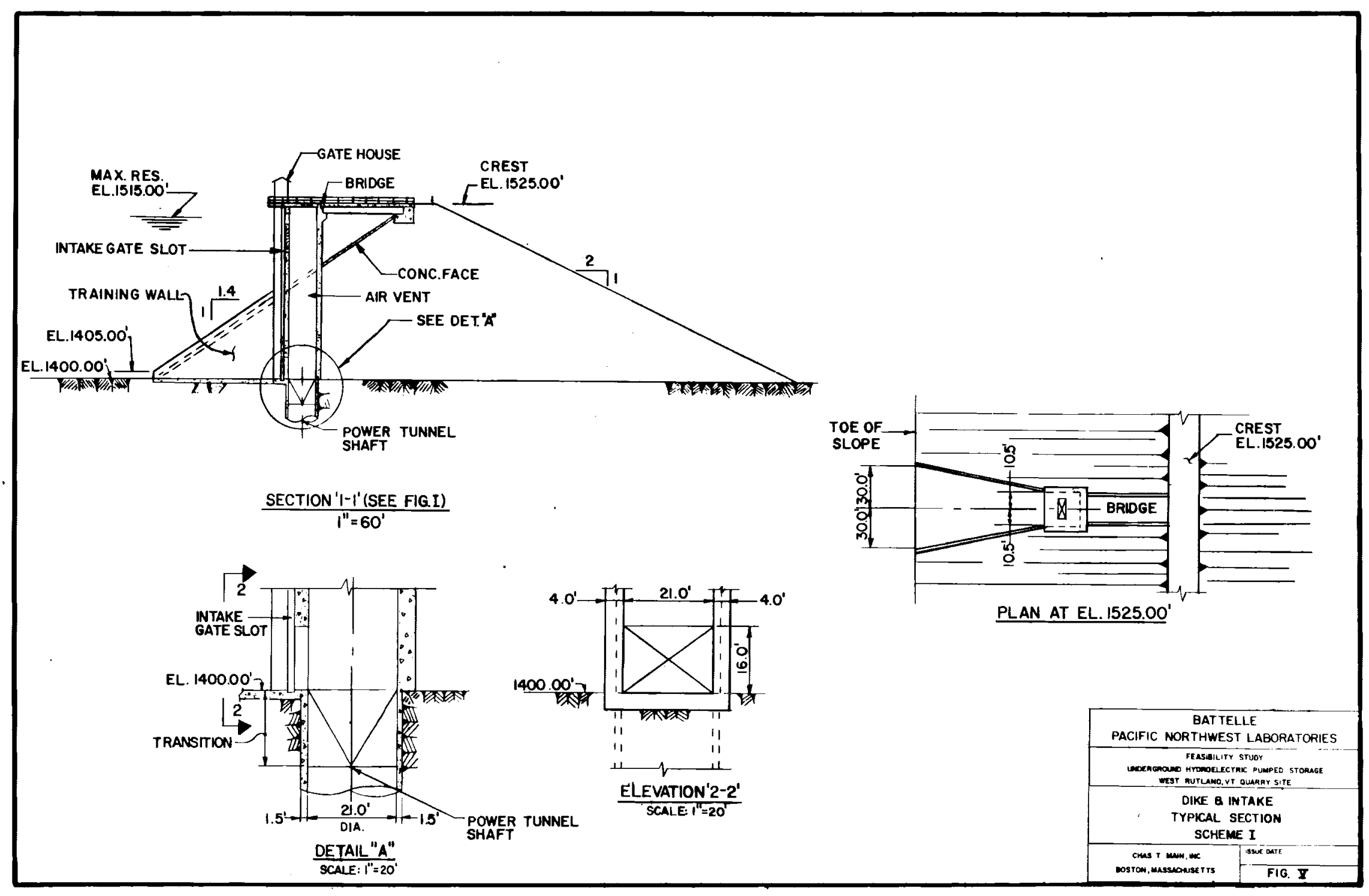


. 


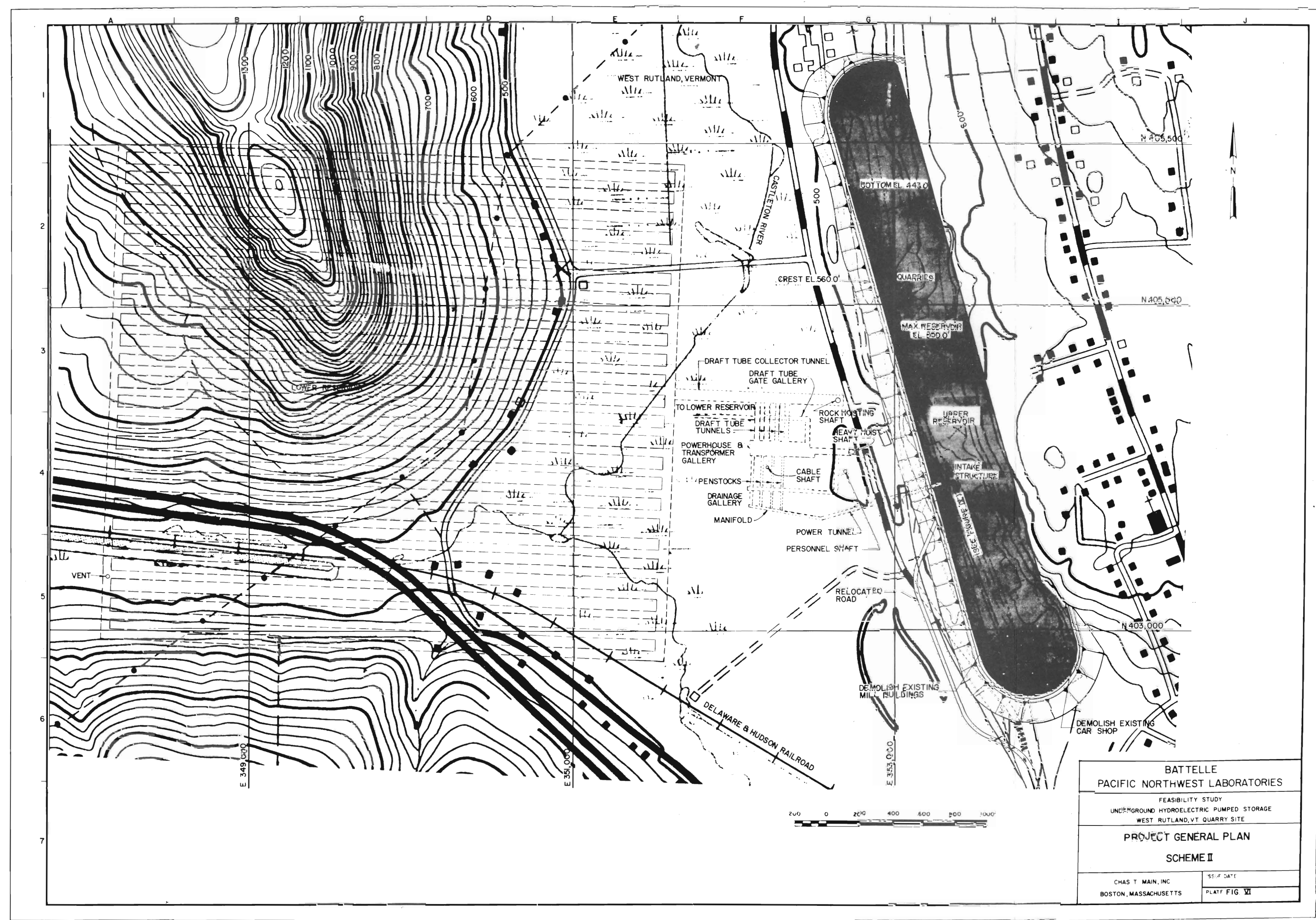





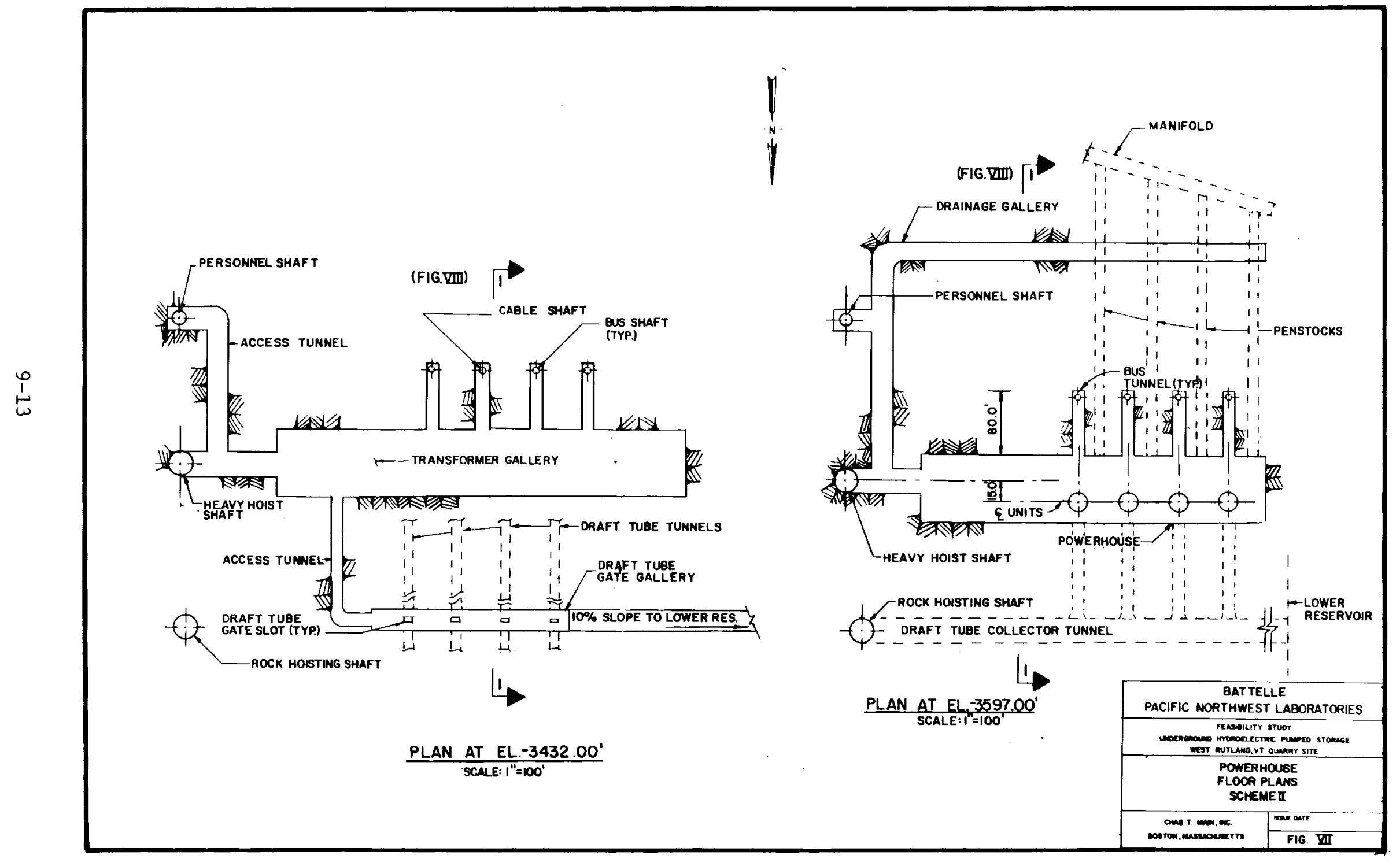




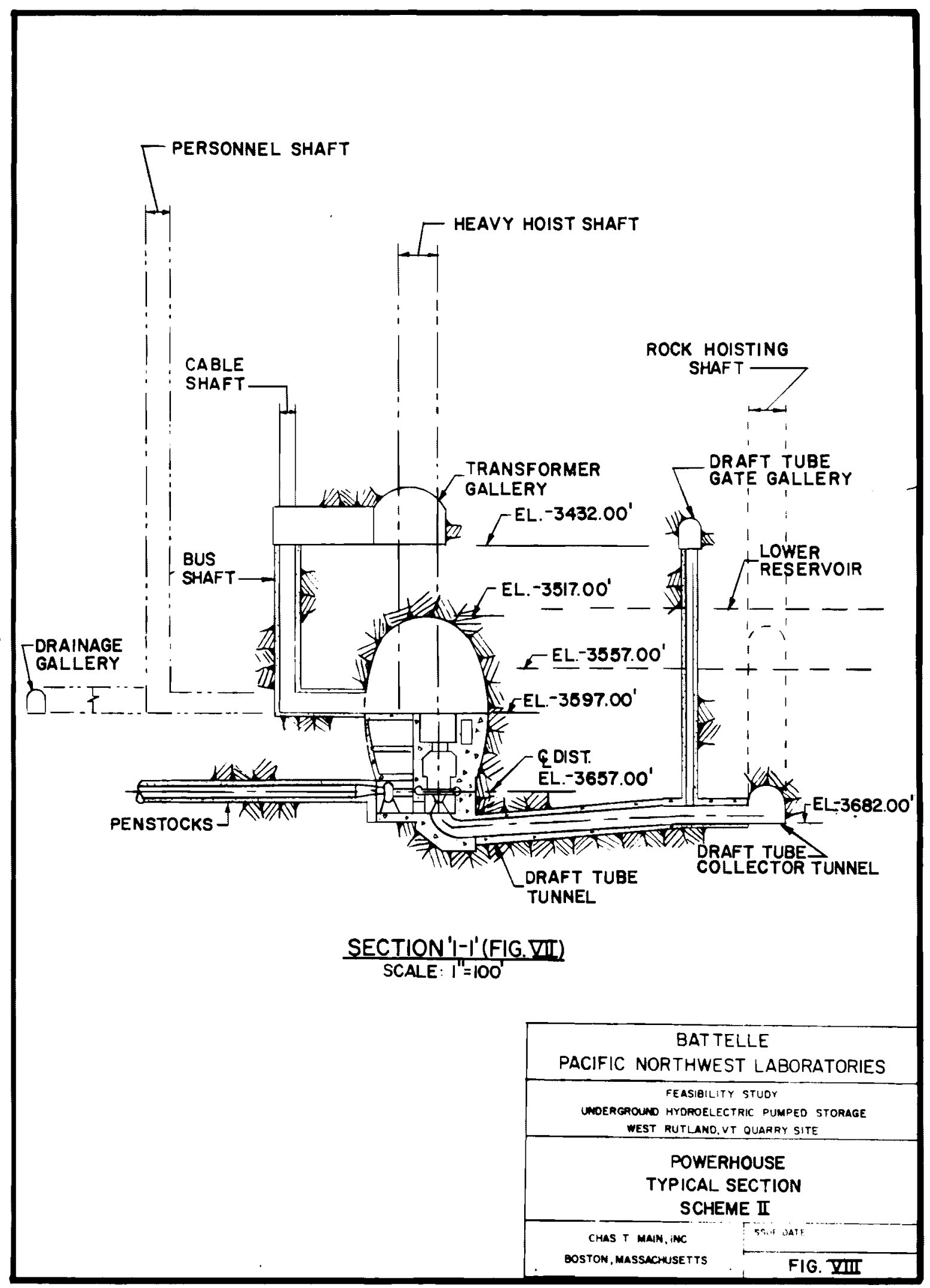




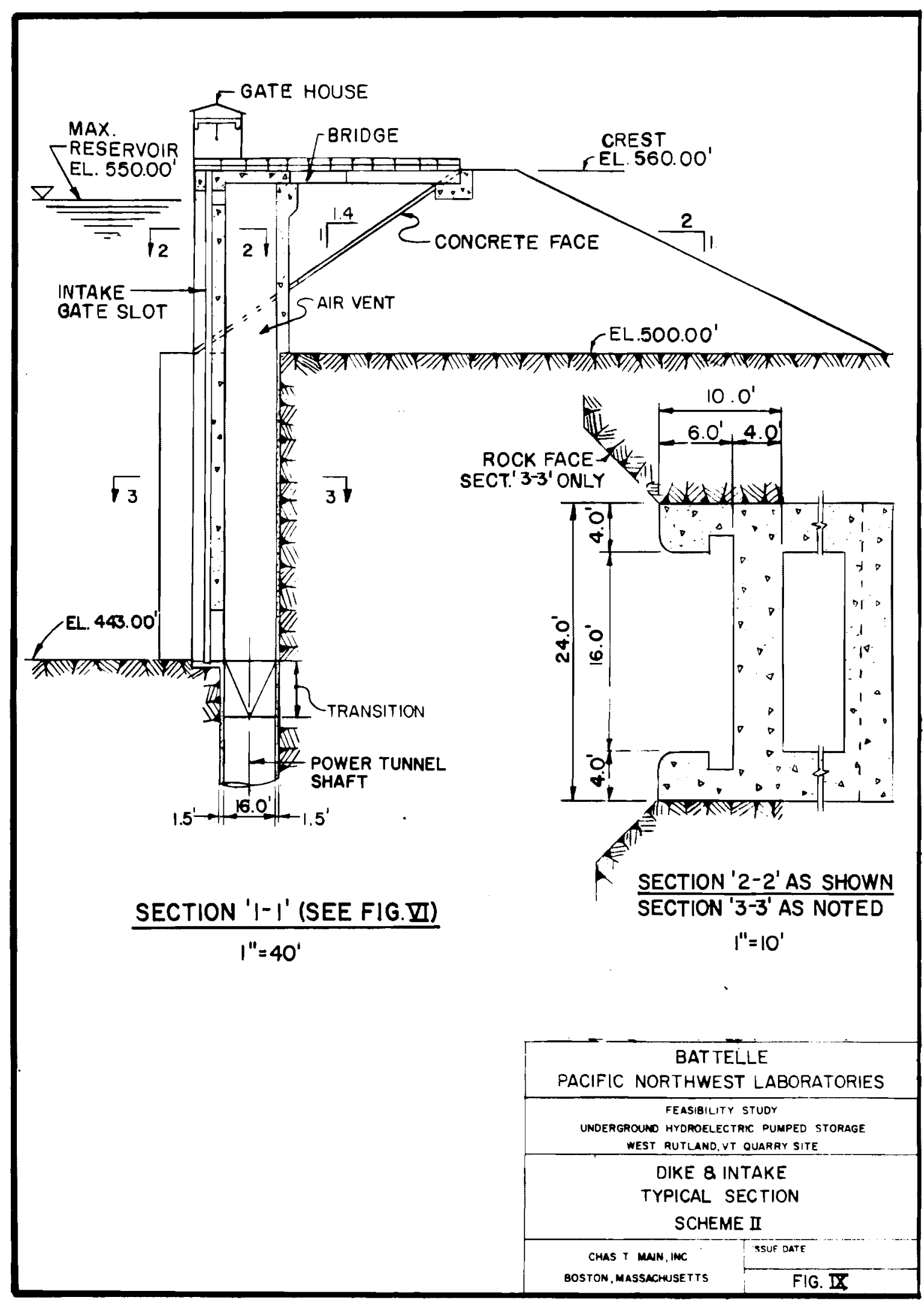




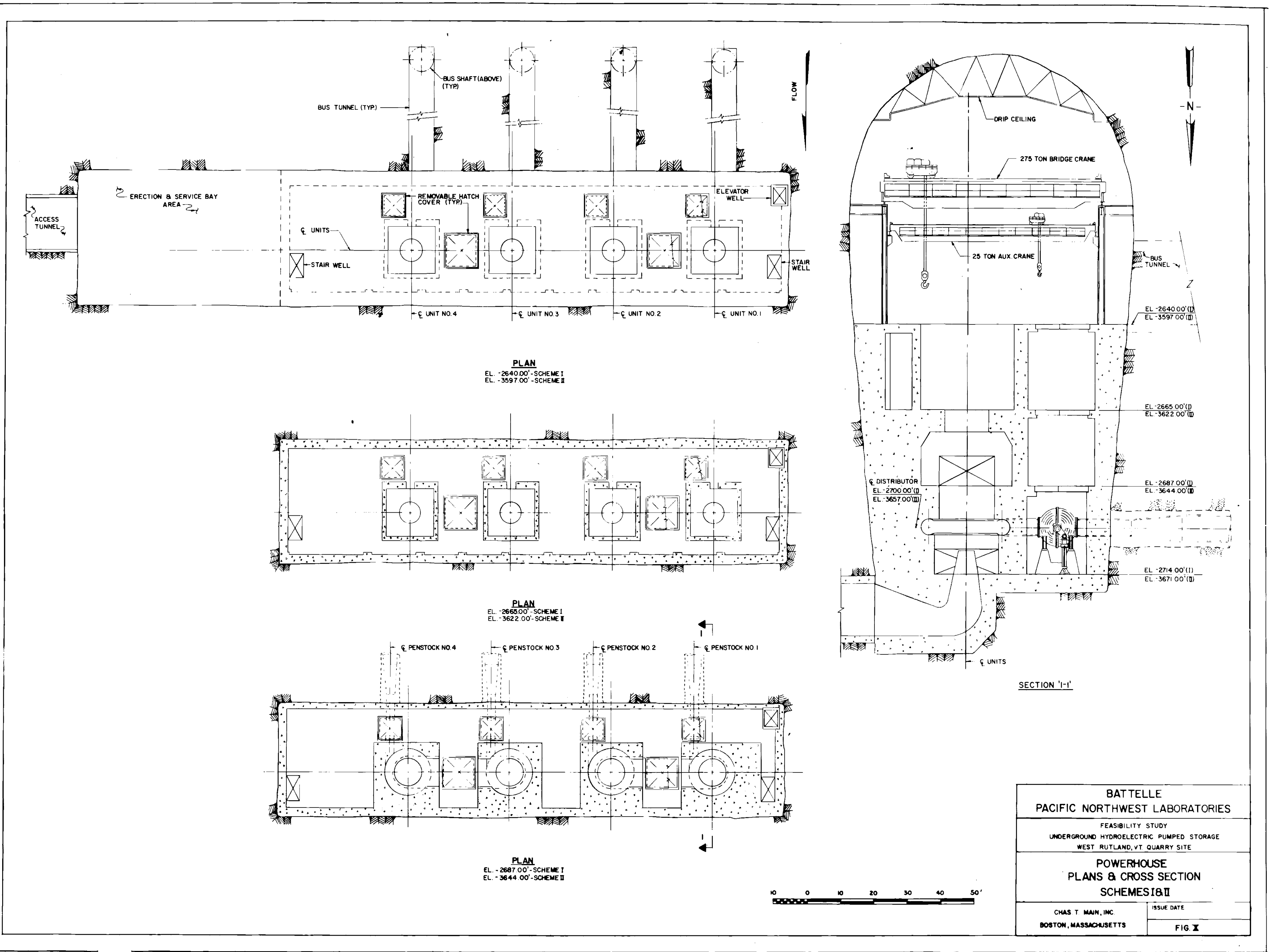




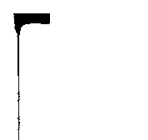

.

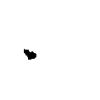

$$
\text { " }
$$

.


APPENDIX

VERMONT UPH STUDY 


\section{VERMONT UPH STUDY}

In order for it to be economical to run a pumped hydro unit, there must be cheap energy available and more costly energy which would normally run which can be displaced. In the case of a peak week, there is less cheap energy available; and in a low load week, there is less expensive encrgy normally running, hence the in-between weeks are the ones with the most pumping activity. Since New England already has several pumped storage units, they were dispatched before the proposed vermont unit. The following cases were run:

\section{Base Case:}

An expansion was created (Appendix 1) in which uncommitted units (12-1150 $\mathrm{NW}$ nuclear, 6-600 Mh coal, 4-300 $\mathrm{Mh}$ pumped storage, 7-100 MW gas turbines) were added in order to achieve a 10 year/day disconnecting customers each year. The base load (coal and nuclear) ranged between $58 \%$ (at the start) to $82 \%$ (at the end) of peak load. During the 20 years (1993-2013) of the study, the total present worth (capital and production costs) came to $\$ 188,666$ million. The percent of maximum usage of uncommitted pumping hydro units (not including 2 weeks/year maintenance) ranged from $60 \%$ to $96.6 \%$.

\section{Case \#1:}

The Vermont UPH unit was added to the Base Case in 1993 only displacing gas turbines, which increased the pumping capacity each year by $1200 \mathrm{MW}$ and resulted in excess capacity in each year of the study. The percent base load remained the same as in the Base Case, however, the percent maximum usage of the uncommitted pumped storage units dropped from $1 \%$ to $3 \%$ in every year (Appendix 4). This would not be detrimental if the fuel displaced was substantially higher priced thar the Base Case displaced fuel or if the fuel used to pump with was considerably lower priced than in the Base Case. This was rot the case and the total present worth for Case \#l came to $\$ 187,446$ million indicating that the capital costs of the Vermont unit must be 254 (1980 dollars) per $\mathrm{KW}$ in order to be as economical as the Base Case.

\section{Case \#2:}

The 4-300 MW pumping hydro units were added in 1996 and displaced the four pumping units which had been added in various years of the base Case (percent base load remained the same in this case also). Since the pond capacities of the Vermont units ( $9000 \mathrm{hrs} / \mathrm{wk}$ ) were smaller than those added in the Base Case $(9960 \mathrm{hrs} / \mathrm{wk})$, the pumping capacity was greater during the first 17 years of the study (due to having more units), and less during the last three years of the study (due to less pond capacity). This resulted in the percent maximum usage of uncommitted pumping units being a few percent below the Base Case for 
the first 17 years and a few percent higher during the last three. The total present worth in this case came to $\$ 187,328$ million indicating capital costs for the Vermont unit must be $336.61980 \mathrm{dollars} / \mathrm{Kh}^{\mathrm{h}}$ in order to be as inexpensive as the Base Case.

It is interesting to note in this case that most savings camce curing the years in which Northfield or Bear Swamp were out on maintenance indicating that the Vermont unit could now use cheaper fuei to pump with and displace a higher priced fuel than it would normally displace had other pumping units not been on maintenance.

Case 3:

The expansion sequence was altered so that the lifh unit was added in 1993 and the addition of base load units delayed to meet the 10 years/day disconnect customers each year. This drcpped the percent of peak base load to a range of $52 \%$ to $79 \%$, and lowered the capacity factors for uncommitted pumping hydro units (see Appendix 3). The present worth capital revenue requirements were lower than in the Base Case for the first six and last two years and higher in the middle years, and the production revenue requirements were higher every year. The total present worth was $\$ 3,811$ million higher than the Base Case meaning capital costs for the Vermont unit would have to be negative.

\section{Case 4:}

The units slated to be converted to coal were left as cil burners (with the exceptions of Brayton Point 1, 2, and 3 and Mt. Tom) and everything else was identical to Case \#2. The percent usage for all pumping units dropped a few percent every ycar. In the carly years of the study (when the percent base load was relatively small) the lisage of the uncommitted unit was 3-4 percent less than in Case $\$ 2$. The total present worth for this case was $\$ 13,880$ million higher than the Base Case (Appendix 5) indicating again that the unit would have to have a negative capital cost to compare favorably with the Base Case. 
UNTESTED FACTORS WHICH MAY AFFECT U.P.H. UNIT FEASIBILITY

\section{ADVERSE EFFECTS}

A. Hydro-Quebec Energy Barking: If cases with energy banking were run, they would have shown that adding the uncomnitted pumped hydro unit would have reduced the savings potential of Hydro-Quebec banking because there would be less energy available for banking. The case where the Vermont unit was added would have been more costly.

B. Hydro-Quebec Economy Energy: Due to modeling problems this case calid not be obtained. It is likely that this would result in having less high priced oil units being run (hence less oil available for displacement) and the usage of the Vermont unit would be low, cutting into savings.

C. Retirement of 0il Units: Since this is predominantly the range of fuel over which the pumped hydro unit would be operating, retirement of oil units would decrease the usage of the unit and cut down on savings.

D. Failure to Achieve Proposed Base Case Base Lcad: As the percent base load decreases, so does the usage of the pumping units (see Appendix 3 ).

\section{BENEFICIAL EFFECTS:}

A. If there turns out to be more expensive fuel to displace than was proposed in the Base Case (perhaps the price of low sulfur oil will rise relative to high sulfur oil or more oil units are added to the systen), then the pumping unit would produce more substartial savings.

B. A larger load growth than anticipated would cause the more expensive units to run more often allowing the unit to displace more and create higher savings. A larger load growth nay also increase the number of base load units being added indicating the pumped hydro unit would receive more usage.

C. If Bear Swamp or Northfield's availability dropped, there would be more opportunity to use the proposed vermont unit. 


\section{SUTRIARY}

In each contingency, the Vermont unit was dispatched after Bear Swamp and Northfield. Both of these units had the opportunity to displace the most expensive fuel while utilizing the cheapest. The Vermont unit was then allowed to operate over the left-over, relatively small price range of fuel (perhaps using high sulfur \#6 oil to displace low sulfur \#6 oil). It then reaches a point where it would be inefficient for it to continue running and it sits idle. The most promising case was Case $\# 2$ (the unit was added in 1996 and displaced the hydro units of the Base Case). It was not used a great deal in the early years of the study (where the base load was around $60 \%$ of peak but was used more extensively as the base load increased. The most substantial savings occurred during years where either Bear Swamp or Northfield were out on maintenance. The savings (as compared to the Ease Case) without including the capital costs of adding the unit came to $\$ 1,338$ million dollars through 2013. This indicated the capital cost of adding the unit in 1996 must be 336.61980 dollars per $\mathrm{KW}$ in order to be as economical as the Base Case. However, there are other factors which will affect this estimate. Factors that will lower this estimate include:

1. Hydro-Quebec energy banking

2. Hydro-Quebec economy entrgy

3. Retirement of oil units

4. Failure to achieve proposed base load.

Factors which will raise this estimate include:

1. Larger load growth than anticipated

2. Availability of on-line pumping units decreases

3. More oil usage than anticipated.

SHP

$11 / 9 / 81$ 


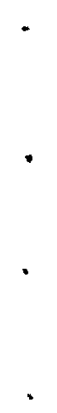


NUCLEAR AND COAL GENERATION AS PERCENT OF PEAK LOAD

\begin{tabular}{|c|c|c|c|c|c|c|}
\hline Year No. & $\underline{\text { Power Year }}$ & Base Case & Case $\|_{1} 1$ & Case $\# 2$ & Case \#3 & Case $\# 4$ \\
\hline 0 & $1992 / 93$ & 53.5 & $\begin{array}{l}\text { Same as } \\
\text { base case }\end{array}$ & $\begin{array}{l}\text { Same as } \\
\text { base case }\end{array}$ & & \\
\hline 1 & $93 / 94$ & 57.6 & 57.6 & 57.6 & 52.2 & 51.2 \\
\hline 2 & $94 / 95$ & 58.9 & 58.9 & 58.9 & 50.8 & 52.7 \\
\hline 3 & $95 / 96$ & 60.5 & 60.5 & 60.5 & 52.7 & 54.3 \\
\hline 4 & $96 / 97$ & 61.8 & 61.8 & 61.8 & 54.1 & 55.8 \\
\hline 5 & $97 / 98$ & 65.1 & 65.1 & 65.1 & 57.7 & 59.2 \\
\hline 6 & $98 / 99$ & 63.6 & 63.6 & 63.6 & 58.7 & 57.8 \\
\hline 7 & $99 / 2000$ & 64.2 & 64.2 & 64.2 & 57.1 & 58.6 \\
\hline 8 & $00 / 01$ & 66.9 & 66.9 & 66.9 & 64.5 & 61.5 \\
\hline 9 & $01 / 02$ & 69.7 & 69.7 & 69.7 & 67.2 & 64.3 \\
\hline 10 & $02 / 03$ & 72.0 & 72.0 & 72.0 & 67.7 & 66.8 \\
\hline 11 & $03 / 04$ & 70.2 & 70.2 & 70.2 & 66.0 & 65.2 \\
\hline 12 & $04 / 05$ & 72.4 & 72.4 & 72.4 & 68.2 & 67.5 \\
\hline 13 & $05 / 06$ & 74.4 & 74.4 & 74.4 & 70.4 & 69.6 \\
\hline 14 & $06 / 07$ & 76.4 & 76.4 & 76.4 & 72.4 & 71.6 \\
\hline 15 & $07 / 08$ & 74.4 & 74.4 & 74.4 & 70.5 & 69.8 \\
\hline 16 & $08 / 09$ & 76.1 & 76.1 & 76.1 & 72.3 & 72.6 \\
\hline 17 & $09 / 10$ & 77.7 & 77.7 & 77.7 & 74.1 & 75.3 \\
\hline 18 & $10 / 11$ & 79.1 & 79.1 & 79.1 & 77.4 & 77.9 \\
\hline 19 & $11 / 12$ & 80.5 & 80.5 & 80.5 & 77.1 & 76.8 \\
\hline 20 & $12 / 13$ & 81.7 & 81.7 & 81.7 & 78.5 & 77.6 \\
\hline
\end{tabular}


APPENDIX 1

A-7 

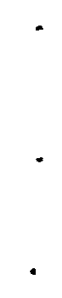

. 
EXPANSION SEQUENCES

\begin{tabular}{|c|c|c|c|c|c|c|}
\hline Study Year & Year No & Base Case & Case 非 & Case \#2 & Case \#3 & Case \#4 \\
\hline $1993-94$ & 1 & $2(600)$ & $2(600)+4(300)$ & $2(600)$ & $4(300)$ & $2(600)$ \\
\hline $94-95$ & 2 & 600 & 600 & 600 & - & 600 \\
\hline $95-96$ & 3 & 600 & 600 & 600 & 600 & 600 \\
\hline $96-97$ & 4 & $600+300$ & $600+300$ & $600+4(300)$ & 600 & $600+4(300)$ \\
\hline $97-98$ & 5 & 1150 & 1150 & 1150 & 1150 & 1150 \\
\hline $98-99$ & 6 & - & - & - & 600 & - \\
\hline $99-00$ & 7 & 600 & 600 & 600 & 1150 & 600 \\
\hline $00-01$ & 8 & $1150+300$ & $1150+300$ & 1150 & $1150+300$ & 1150 \\
\hline $01-02$ & 9 & 1150 & 1150 & 1150 & 1150 & 1150 \\
\hline $02-03$ & 10 & 1150 & 1150 & 1150 & 600 & 1150 \\
\hline $03-04$ & 11 & - & - & - & - & - \\
\hline $04-05$ & 12 & $1150+300$ & $1150+300$ & 1150 & $1150+300$ & 1150 \\
\hline $05-06$ & 13 & $1150+3(100)$ & 1150 & 1150 & $1150+300$ & 1150 \\
\hline $06-07$ & 14 & 1150 & 1150 & 1150 & 1150 & 1150 \\
\hline $07-08$ & 15 & $2(100)$ & - & $2(100)$ & $2(100)$ & 100 \\
\hline $08-09$ & 16 & $1150+100$ & 1150 & 1150 & 1150 & $1150+100$ \\
\hline $09-10$ & 17 & 1150 & 1150 & $1150+100$ & $1150+100$ & 1150 \\
\hline $10-11$ & 18 & $1150+300+100$ & $1150+300$ & $1150+3(100)$ & $1150+600+3(100)$ & $1150+3(100)$ \\
\hline $11-12$ & 19 & 1150 & 1150 & 1150 & 600 & 1150 \\
\hline $12-13$ & 20 & 1150 & 1150 & $1150+100$ & 1150 & $1150+2(100)$ \\
\hline \multirow[t]{4}{*}{ TOTAL } & & $6(600)$ & $6(600)$ & $6(600)$ & $6(600)$ & $6(600)$ \\
\hline & & $12(1150)$ & $12(1150)$ & $12(1150)$ & $11(1150)$ & $12(1150)$ \\
\hline & & $4(300)$ & $8(300)$ & $4(300)$ & $7(300)$ & $4(300)$ \\
\hline & & $7(100)$ & - & $7(100)$ & $6(100)$ & $7(100)$ \\
\hline
\end{tabular}


. 
APPENDIX 2

A-11 

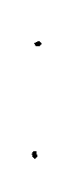
CVPS - UPHS STUDY - BASE CASE

Summary of System Generation Mix in Percent of Power Year Forecast Peak

\begin{tabular}{|c|c|c|c|c|c|c|c|c|c|c|c|c|c|}
\hline $\begin{array}{l}\text { Year } \\
\text { No. } \\
\end{array}$ & $\begin{array}{l}\text { Study } \\
\text { Year } \\
\end{array}$ & $\begin{array}{l}\% \text { Base } \\
\text { Load } \\
\text { Coa1 } \\
\end{array}$ & $\begin{array}{l}\% \text { Base } \\
\text { Load } \\
\text { O11 } \\
\end{array}$ & $\begin{array}{c}\% \\
\text { Nuclear } \\
\end{array}$ & $\begin{array}{l}\% \text { Total } \\
\text { Base } \\
\text { Load } \\
\end{array}$ & $\begin{array}{l}\% \text { Ties } \\
\text { \&OP } 4 * \\
\end{array}$ & $\begin{array}{c}\% \\
\text { Cyc1ing } \\
\text { Fossil } \\
\end{array}$ & \begin{tabular}{l}
\multicolumn{1}{c}{$\%$} \\
Internal \\
Combustion \\
\end{tabular} & $\begin{array}{c}\% \\
\text { Conv. } \\
\text { Hydro } \\
\end{array}$ & $\begin{array}{c}\% \\
\text { Pumping } \\
\text { Hydro } \\
\end{array}$ & $\begin{array}{c}\begin{array}{c}\text { Total } \\
\% \\
\text { Reserve } \\
\end{array} \\
\end{array}$ & $\begin{array}{c}\text { Total } \\
\% \\
\text { Gen } \\
\end{array}$ & $\begin{array}{c}\text { MW } \\
\text { Peak } \\
\text { Load } \\
\end{array}$ \\
\hline 0 & $1992 / 93$ & & & & & & & & & & & & \\
\hline 1 & $1993 / 94$ & 22.4 & 7.1 & 35.2 & 64.7 & 8.8 & 33.8 & 8.2 & 6.9 & 7.4 & 129.8 & 121.0 & 22130 \\
\hline 2 & $1994 / 95$ & 24.5 & 6.9 & 34.4 & 65.8 & 8.7 & 33.1 & 8.0 & 6.7 & 7.2 & 129.5 & 120.8 & 22610 \\
\hline 3 & 1995 & 26.7 & 6.8 & 33.8 & 67.3 & 8.6 & 32.4 & 7.8 & 6.6 & 7.1 & 129.8 & 121.2 & 23060 \\
\hline 4 & 1996 & 28.7 & 6.7 & 33.1 & 68.5 & 8.5 & 31.8 & 7.7 & 6.4 & 8.2 & 131.1 & 122.6 & 23530 \\
\hline 5 & 1997 & 28.0 & 6.5 & 37.1 & 71.6 & 8.4 & 31.1 & 7.5 & 6.3 & 8.0 & 132.9 & 124.5 & 24110 \\
\hline 6 & 1998 & 27.4 & 6.3 & 36.2 & 69.9 & 8.3 & 30.2 & 7.3 & 6.1 & 7.8 & 129.6 & 121.3 & 24720 \\
\hline 7 & 1999 & 29.0 & 6.2 & 35.2 & 70.4 & 8.2 & 29.5 & 7.1 & 6.0 & 7.6 & 128.8 & 120.6 & 25380 \\
\hline 8 & 2000 & 28.2 & 6.0 & 38.7 & 72.9 & 8.1 & 28.8 & 6.9 & 5.8 & 8.6 & 131.1 & 123.0 & 26040 \\
\hline 9 & 2001 & 27.6 & 5.9 & 42.1 & 75.6 & 8.0 & 28.0 & 6.8 & 5.7 & 8.3 & 132.4 & 124.4 & 26720 \\
\hline 10 & 2002 & 26.8 & 5.1 & 45.2 & 77.7 & 8.0 & 27.3 & 6.6 & 5.5 & 8.1 & 133.2 & 125.2 & 27410 \\
\hline 11 & 2003 & 26.1 & 5.6 & 44.1 & 75.8 & 7.9 & 26.6 & 6.4 & 5.4 & 7.9 & 130.0 & 122.1 & 28120 \\
\hline 12 & 2004 & 25.5 & 5.4 & 46.9 & 77.8 & 7.8 & 25.9 & 6.3 & 5.3 & 8.8 & 131.9 & 124.1 & 28860 \\
\hline 13 & 2005 & 24.8 & 5.3 & 49.6 & 79.7 & 7.7 & 25.3 & 7.1 & 5.1 & 8.5 & 133.4 & 125.7 & 29610 \\
\hline 14 & 2006 & 24.3 & 5.2 & 52.1 & 81.6 & 7.6 & 24.6 & 6.9 & 5.0 & 7.3 & 133.0 & 125.4 & 30380 \\
\hline 15 & 2007 & 23.6 & 5.0 & 50.8 & 79.4 & 7.5 & 24.0 & 7.4 & 4.9 & 8.1 & 131.3 & 123.8 & 31170 \\
\hline 16 & 2008 & 23.0 & 4.9 & 53.1 & 81.0 & 7.4 & 23.4 & 7.5 & 4.7 & 7.9 & 131.9 & 124.5 & 31980 \\
\hline 17 & 2009 & 22.4 & 4.8 & 55.3 & 82.5 & 7.3 & 22.8 & 7.3 & 4.6 & 7.7 & 132.2 & 124.9 & 32810 \\
\hline 18 & 2010 & 21.8 & 4.7 & 57.3 & 83.8 & 7.2 & 22.3 & 7.4 & 4.5 & 8.4 & 133.6 & 126.4 & 33660 \\
\hline 19 & 2011 & 21.3 & 4.5 & 59.2 & 85.0 & 7.1 & 21.6 & 7.3 & 4.4 & 8.2 & 133.6 & 126.5 & 34540 \\
\hline 20 & 2012 & 20.8 & 4.4 & 60.9 & 86.1 & 7.0 & 21.1 & 7.1 & 4.3 & 8.0 & 133.6 & 126.6 & 35430 \\
\hline
\end{tabular}


CASE \# 1 CVPS UPHS STUDY

Summary of System Generation Mix in Percent of Power Year Forecast Peak

\begin{tabular}{|c|c|c|c|c|c|c|c|c|c|c|c|c|}
\hline $\begin{array}{l}\text { Study } \\
\text { Year }\end{array}$ & $\begin{array}{r}\text { Year } \\
\text { No. }\end{array}$ & $\begin{array}{c}\% \\
\text { Base } \\
\text { Load } \\
\text { Coal } \\
\end{array}$ & \begin{tabular}{l}
\multicolumn{1}{c}{$\%$} \\
Base \\
Load \\
Oi1 \\
\end{tabular} & $\begin{array}{c}\% \\
\text { Nuclear } \\
\end{array}$ & \begin{tabular}{l}
\multicolumn{1}{c}{$\%$} \\
Tota1 \\
Base \\
Load \\
\end{tabular} & $\begin{array}{c}\% \text { Ties } \\
\& 0 P 4^{*} \\
\end{array}$ & $\begin{array}{c}\% \\
\text { Cycling } \\
\text { Fossil } \\
\end{array}$ & $\begin{array}{c}\% \\
\text { Internal } \\
\text { Combustion } \\
\end{array}$ & $\begin{array}{c}\% \\
\text { Conv. } \\
\text { Hydro } \\
\end{array}$ & $\begin{array}{c}\% \\
\text { Pumping } \\
\text { Hydro } \\
\end{array}$ & $\begin{array}{c}\text { Total } \\
\% \\
\text { Gen } \\
\end{array}$ & $\begin{array}{l}\text { MW } \\
\text { Peak } \\
\text { Load }\end{array}$ \\
\hline $1992 / 93$ & 0 & & & & & & & & & & & \\
\hline $93 / 94$ & 1 & 22.4 & 7.1 & 35.2 & 64.7 & 8.8 & 33.8 & 8.2 & 6.9 & 12.8 & 126.4 & 22130 \\
\hline $94 / 95$ & 2 & 24.5 & 6.9 & 34.4 & 65.8 & 8.7 & 33.1 & 8.0 & 6.7 & 12.5 & 126.1 & 22610 \\
\hline $95 / 96$ & 3 & 26.7 & 6.8 & 33.8 & 67.3 & 8.6 & 32.4 & 7.8 & 6.6 & 12.3 & 126.4 & 23060 \\
\hline $96 / 97$ & 4 & 28.7 & 6.7 & 33.1 & 68.5 & 8.5 & 31.8 & 7.7 & 6.4 & 13.3 & 127.7 & 23530 \\
\hline $97 / 98$ & 5 & 28.0 & 6.5 & 37.1 & 71.6 & 8.4 & 31.1 & 7.5 & 6.3 & 13.0 & 129.5 & 24110 \\
\hline $98 / 99$ & 6 & 27.4 & 6.3 & 36.2 & 69.9 & 8.3 & 30.2 & 7.3 & 6.1 & 12.7 & 126.2 & 24720 \\
\hline $99 / 2000$ & 7 & 29.0 & 6.2 & 35.2 & 70.4 & 8.2 & 29.5 & 7.1 & 6.0 & 12.3 & 125.3 & 25380 \\
\hline $2000 / 2001$ & 8 & 28.2 & 6.0 & 38.7 & 72.9 & 8.1 & 28.8 & 6.9 & 5.8 & 13.2 & 127.6 & 26040 \\
\hline $01 / 02$ & 9 & 27.6 & 5.9 & 42.1 & 75.6 & 8.0 & 28.0 & 6.8 & 5.7 & 12.8 & 128.9 & 26720 \\
\hline $02 / 03$ & 10 & 26.8 & 5.7 & 45.2 & . 77.7 & 8.0 & 27.3 & 6.6 & 5.5 & 12.5 & 129.6 & 27410 \\
\hline $03 / 04$ & 11 & 26.1 & 5.6 & 44.1 & 75.8 & 7.9 & 26.6 & 6.4 & 5.4 & 12.2 & 126.2 & 28120 \\
\hline $04 / 05$ & 12 & 25.5 & 5.4 & 46.9 & 77.8 & 7.8 & 25.9 & 6.3 & 5.3 & 12.9 & 128.2 & 28860 \\
\hline $05 / 06$ & 13 & 24.8 & 5.3 & 49.6 & 79.7 & 7.7 & 25.3 & 6.1 & 5.1 & 12.6 & 128.8 & 29610 \\
\hline $06 / 07$ & 14 & 24.3 & 5.2 & 52.1 & 81.6 & 7.6 & 24.6 & 5.9 & 5.0 & 12.3 & 129.4 & 30380 \\
\hline $07 / 08$ & 15 & 23.6 & 5.0 & 50.8 & 79.4 & 7.5 & 24.0 & 5.8 & 4.9 & 12.0 & 126.1 & 31170 \\
\hline $08 / 09$ & 16 & 23.0 & 4.9 & 53.1 & 81.0 & 7.4 & 23.4 & 5.6 & 4.7 & 11.7 & 126.4 & 31980 \\
\hline $09 / 10$ & 17 & 22.4 & 4.8 & 55.3 & 82.5 & 7.3 & 22.8 & 5.5 & 4.6 & 11.4 & 126.8 & 32810 \\
\hline $10 / 11$ & 18 & 21.8 & 4.7 & 57.3 & 83.8 & 7.2 & 22.3 & 5.4 & 4.5 & 12.0 & 128.0 & 33660 \\
\hline $11 / 12$ & 19 & 21.3 & 4.5 & 59.2 & 85.0 & 7.1 & 21.6 & 5.2 & 4.4 & 11.7 & 127.9 & 34540 \\
\hline $12 / 13$ & 20 & 20.8 & 4.4 & 60.9 & 86.1 & 7.0 & 21.1 & 5.1 & 4.3 & 11.4 & 128.0 & 35430 \\
\hline
\end{tabular}

*operation Process 非 4 
CVPS STUDY CASE 非 (UPS UNIT ADDED IN 1996)

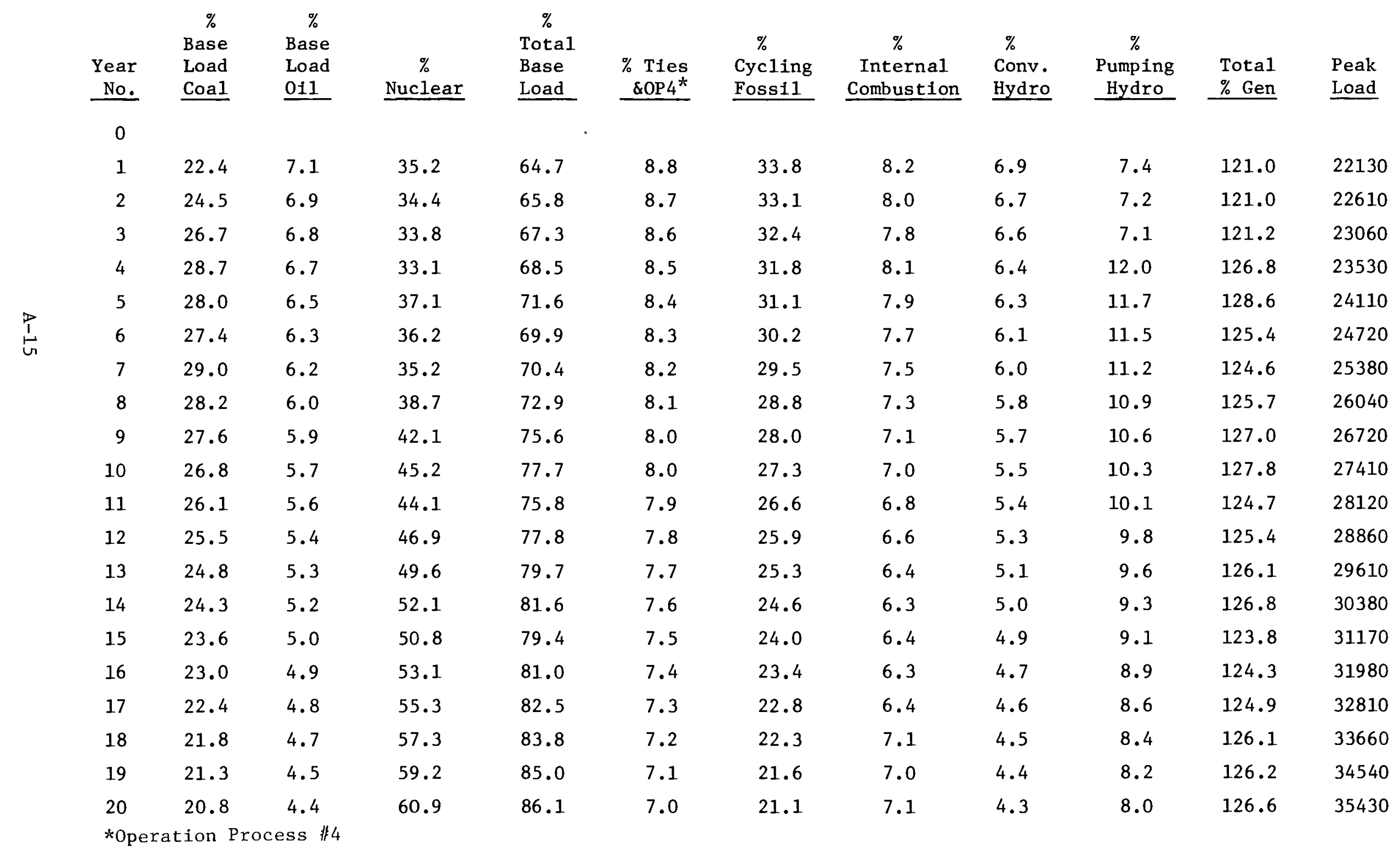


CVPS UPHS STUDY CASE \#3

System Generation Mix in Percent of Power Year Forecast Peak

\begin{tabular}{|c|c|c|c|c|c|c|c|c|c|c|c|c|}
\hline $\begin{array}{r}\text { Study } \\
\text { Year }\end{array}$ & $\begin{array}{l}\text { Year } \\
\text { No. }\end{array}$ & $\begin{array}{c}\% \\
\text { Base } \\
\text { Load } \\
\text { Coal } \\
\end{array}$ & \begin{tabular}{l}
\multicolumn{1}{c}{$\%$} \\
Base \\
Load \\
Oil \\
\end{tabular} & $\begin{array}{c}\% \\
\text { Nuclear } \\
\end{array}$ & \begin{tabular}{l}
\multicolumn{1}{c}{$\%$} \\
Total \\
Base \\
Load \\
\end{tabular} & $\begin{array}{l}\% \text { Ties } \\
\text { \&OP } 4^{*} \\
\end{array}$ & $\begin{array}{c}\% \\
\text { Cycling } \\
\text { Fossil } \\
\end{array}$ & $\begin{array}{c}\% \\
\text { Internal } \\
\text { Combustion } \\
\end{array}$ & $\begin{array}{l}\% \\
\text { Conv. } \\
\text { Hydro } \\
\end{array}$ & $\begin{array}{c}\% \\
\text { Pumping } \\
\text { Hydro } \\
\end{array}$ & $\begin{array}{l}\text { Total } \\
\% \text { Gen } \\
\end{array}$ & $\begin{array}{c}\text { MW } \\
\text { Peak } \\
\text { Load } \\
\end{array}$ \\
\hline $1992 / 93$ & 0 & & & & & & & & & & & \\
\hline $93 / 94$ & 1 & 17.0 & 7.1 & 35.2 & 59.3 & 8.8 & 33.7 & 8.2 & 6.9 & 12.8 & 120.9 & 22130 \\
\hline $94 / 95$ & 2 & 16.6 & 6.9 & 34.4 & 57.9 & 8.7 & 33.0 & 8.0 & 6.7 & 12.5 & 118.1 & 22610 \\
\hline $95 / 96$ & 3 & 18.9 & 6.8 & 33.8 & 59.5 & 8.6 & 32.3 & 7.8 & 6.6 & 12.3 & 118.5 & 23060 \\
\hline $96 / 97$ & 4 & 21.1 & 6.7 & 33.1 & 60.8 & 8.5 & 31.7 & 7.7 & 6.4 & 12.0 & 118.6 & 23530 \\
\hline $97 / 98$ & 5 & 20.6 & 6.5 & 37.1 & 64.2 & 8.4 & 30.9 & 7.5 & 6.3 & 11.7 & 120.6 & 24110 \\
\hline $98 / 99$ & 6 & 22.5 & 6.3 & 36.2 & 65.0 & 8.3 & 30.1 & 7.3 & 6.1 & 11.5 & 120.0 & 24720 \\
\hline $99 / 2000$ & 7 & 21.9 & 6.2 & 39.8 & 63.3 & 8.2 & 29.4 & 7.1 & 6.0 & 11.2 & 117.0 & 25380 \\
\hline $2000 / 01$ & 8 & 21.3 & 6.0 & 43.2 & 70.5 & 8.1 & 28.6 & 6.9 & 5.8 & 12.0 & 123.8 & 26040 \\
\hline $01 / 02$ & 9 & 20.8 & 5.9 & $46.4^{\circ}$ & 73.1 & 8.0 & 27.9 & 6.8 & 5.7 & 11.7 & 125.2 & 26720 \\
\hline $02 / 03$ & 10 & 22.5 & 5.7 & 45.2 & 73.4 & 8.0 & 27.2 & 6.6 & 5.5 & 11.4 & 124.1 & 27410 \\
\hline $03 / 04$ & 11 & 21.9 & 5.6 & 44.1 & 71.6 & 7.9 & 26.5 & 6.4 & 5.4 & 11.1 & 121.0 & 28120 \\
\hline $04 / 05$ & 12 & 21.3 & 5.4 & 46.9 & 73.6 & 7.8 & 25.8 & 6.3 & 5.3 & 11.9 & 122.9 & 28860 \\
\hline $05 / 06$ & 13 & 20.8 & 5.3 & 49.6 & 75.7 & 7.7 & 25.2 & 6.1 & 5.1 & 12.6 & 124.7 & 29610 \\
\hline $06 / 07$ & 14 & 20.3 & 5.2 & 52.1 & 77.6 & 7.6 & 24.5 & 5.9 & 5.0 & 12.3 & 125.3 & 30380 \\
\hline $07 / 08$ & 15 & 19.7 & 5.0 & 50.8 & 75.5 & 7.5 & 23.9 & 6.4 & 4.9 & 12.0 & 122.7 & 31170 \\
\hline $08 / 09$ & 16 & 19.2 & 4.9 & 53.1 & 77.2 & 7.4 & 23.3 & 6.3 & 4.7 & 11.7 & 123.2 & 31980 \\
\hline $09 / 10$ & 17 & 18.8 & 4.8 & 55.3 & 78.9 & 7.3 & 22.7 & 6.4 & 4.6 & 11.4 & 124.0 & 32810 \\
\hline $10 / 11$ & 18 & 20.1 & 4.7 & 57.3 & 82.1 & 7.2 & 22.1 & 7.1 & 4.5 & 11.1 & 126.9 & 33660 \\
\hline $11 / 12$ & 19 & 21.3 & 4.5 & 55.8 & 81.6 & 7.1 & 21.6 & 7.0 & 4.4 & 10.8 & 125.4 & 34540 \\
\hline $12 / 13$ & 20 & 20.8 & 4.4 & 57.7 & 82.9 & 7.0 & 21.0 & 6.8 & 4.3 & 10.5 & 125.5 & 35430 \\
\hline
\end{tabular}

*Operation Process \#4 
CVPS UPH STUDY - CASE \#4

\begin{tabular}{|c|c|c|c|c|c|c|c|c|c|c|c|}
\hline $\begin{array}{l}\text { Year } \\
\text { No. }\end{array}$ & $\begin{array}{c}\% \\
\text { Base } \\
\text { Load } \\
\text { Coal } \\
\end{array}$ & $\begin{array}{c}\% \\
\text { Base } \\
\text { Load } \\
\text { Oi1 } \\
\end{array}$ & $\begin{array}{c}\% \\
\text { Nuclear } \\
\end{array}$ & \begin{tabular}{l}
\multicolumn{1}{c}{$\%$} \\
Total \\
Base \\
Load \\
\end{tabular} & $\begin{array}{l}\% \text { Ties } \\
\text { +0P4* } \\
\end{array}$ & $\begin{array}{c}\% \\
\text { Cycling } \\
\text { Fossil } \\
\end{array}$ & $\begin{array}{c}\% \\
\text { Interna1 } \\
\text { Combustion } \\
\end{array}$ & $\begin{array}{c}\% \\
\text { Conv. } \\
\text { Hydro } \\
\end{array}$ & $\begin{array}{c}\% \\
\text { Pumping } \\
\text { Hydro } \\
\end{array}$ & $\begin{array}{l}\text { Total } \\
\% \text { Gen } \\
\end{array}$ & $\begin{array}{l}\text { Peak } \\
\text { Load }\end{array}$ \\
\hline \multicolumn{12}{|l|}{0} \\
\hline 1 & 16.0 & 7.8 & 35.2 & 59.0 & 8.8 & 33.8 & 8.2 & 6.9 & 7.4 & 115.3 & 22130 \\
\hline 2 & 18.3 & 7.6 & 34.4 & 60.3 & 8.7 & 33.1 & 8.0 & 6.7 & 7.2 & 115.3 & 22610 \\
\hline 3 & 20.5 & 7.5 & 33.8 & 61.8 & 8.6 & 32.4 & 7.8 & 6.6 & 7.1 & 115.7 & 23060 \\
\hline 4 & 22.7 & 7.3 & 33.1 & 63.1 & 8.5 & 31.8 & 8.1 & 6.4 & 12.0 & 121.4 & 23530 \\
\hline 5 & 22.1 & 7.1 & 37.1 & 66.3 & 8.4 & 31.1 & 7.9 & 6.3 & 11.7 & 123.3 & 24110 \\
\hline 6 & 21.6 & 6.9 & 36.2 & 64.7 & 8.3 & 30.2 & 7.7 & 6.1 & 11.5 & 120.2 & 24720 \\
\hline 7 & 23.4 & 6.8 & 35.2 & 65.4 & 8.2 & 29.5 & 7.5 & 6.0 & 11.2 & 119.6 & 25380 \\
\hline 8 & 22.8 & 6.6 & 38.7 & 68.1 & 8.1 & 28.8 & 7.3 & 5.8 & 10.9 & 120.9 & 26040 \\
\hline 9 & 22.2 & 6.4 & 42.1 & 70.7 & 8.0 & 28.0 & 7.1 & 5.7 & 10.6 & 122.1 & 26720 \\
\hline 10 & 21.6 & 6.3 & 45.2 & 73.1 & 8.0 & 27.3 & 7.0 & 5.5 & 10.3 & 123.2 & 27410 \\
\hline 11 & 21.1 & 6.1 & 44.1 & 71.3 & 7.9 & 26.6 & 6.8 & 5.4 & 10.1 & 120.2 & 28120 \\
\hline 12 & 20.6 & 6.0 & 46.9 & 73.5 & 7.8 & 25.9 & 6.6 & 5.3 & 9.8 & 121.1 & 28860 \\
\hline 13 & 20.0 & 5.8 & 49.6 & 75.4 & 7.7 & 25.3 & 6.4 & 5.1 & 9.6 & 121.8 & 29610 \\
\hline 14 & 19.5 & 5.7 & 52.1 & 77.3 & 7.6 & 24.6 & 6.3 & 5.0 & 9.3 & 122.5 & 30380 \\
\hline 15 & 19.0 & 5.5 & 50.8 & 75.3 & 7.5 & 24.0 & 6.4 & 4.9 & 9.1 & 119.7 & 31170 \\
\hline 16 & 19.5 & 5.4 & 53.1 & 78.0 & 7.4 & 23.4 & 6.3 & 4.7 & 8.9 & 121.3 & 31980 \\
\hline 17 & 20.0 & 5.2 & 55.3 & 80.5 & 7.3 & 22.8 & 6.4 & 4.6 & 8.6 & 122.9 & 32810 \\
\hline 18 & 20.6 & 5.1 & 57.3 & 83.0 & 7.2 & 22.3 & 7.1 & 4.5 & 8.4 & 125.3 & 33660 \\
\hline 19 & 17.6 & 5.0 & 59.2 & 81.8 & 7.1 & 21.6 & 7.0 & 4.4 & 8.2 & 123.0 & 34540 \\
\hline 20 & 16.7 & 4.8 & 60.9 & 82.4 & 7.0 & 21.1 & 7.1 & 4.3 & 8.0 & 122.9 & 35430 \\
\hline
\end{tabular}

*Operation Process 非 

APPENDIX 3

A-19 


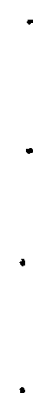




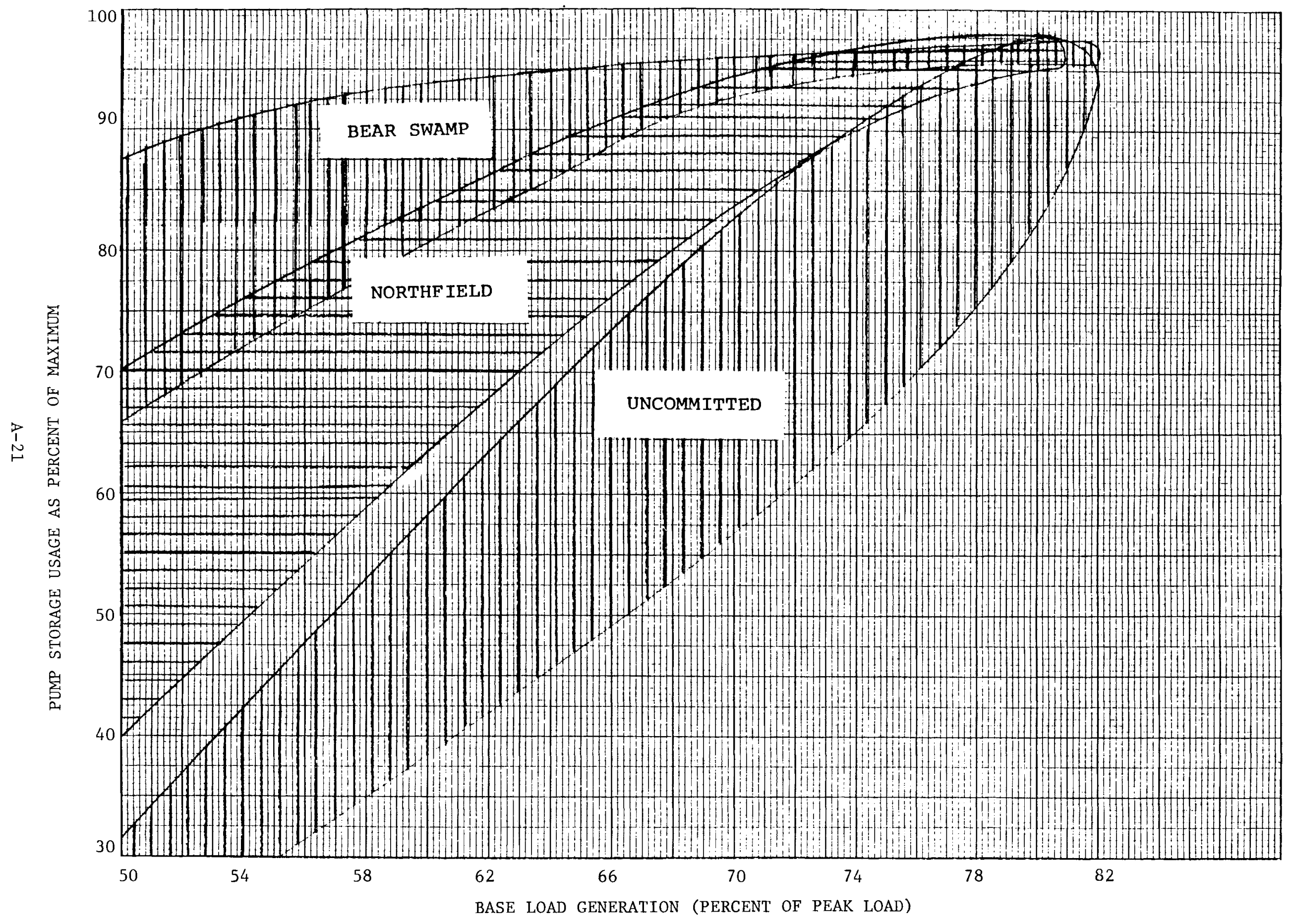




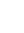


APPENDIX 4

A-23 


\section{CAPACITY FACTORS FOR PUMPED STORAGE UNITS}

Bear Swamp $(\operatorname{Max}=14.8 \%)$

\begin{tabular}{|c|c|c|c|c|c|c|}
\hline $\begin{array}{r}\text { Study } \\
\text { Year } \\
\end{array}$ & $\begin{array}{l}\text { Year } \\
\text { No. }\end{array}$ & $\begin{array}{l}\text { Base } \\
\text { Case }\end{array}$ & $\begin{array}{c}\text { Case } \\
1 \\
\end{array}$ & $\begin{array}{c}\text { Case } \\
3 \\
\end{array}$ & $\begin{array}{c}\text { Case } \\
2 \\
\end{array}$ & $\begin{array}{c}\text { Case } \\
4 \\
\end{array}$ \\
\hline 1992-1993 & 0 & & & & & \\
\hline $93 / 94$ & 1 & 12.2 & 12.6 & 12.7 & 12.2 & 9.3 \\
\hline $94 / 95$ & 2 & 12.4 & 13.0 & 13.0 & 12.4 & 9.8 \\
\hline $95 / 96$ & 3 & 12.5 & 12.8 & 13.1 & 12.5 & 9.8 \\
\hline $96 / 97$ & 4 & 9.1 & 9.2 & 9.2 & 9.2 & 7.3 \\
\hline $97 / 98$ & 5 & 13.2 & 13.2 & 13.3 & 12.9 & 10.8 \\
\hline $98 / 99$ & 6 & 13.3 & 13.4 & 13.6 & 13.5 & 11.8 \\
\hline $99 / 00$ & 7 & 13.8 & 13.7 & 13.6 & 13.4 & 11.7 \\
\hline $00 / 01$ & 8 & 13.6 & 13.9 & 13.6 & 13.8 & 12.0 \\
\hline $01 / 02$ & 9 & 9.7 & 9.8 & 9.8 & 9.8 & 8.9 \\
\hline $02 / 03$ & 10 & 14.0 & 14.1 & 13.9 & 14.2 & 12.6 \\
\hline $03 / 04$ & 11 & 14.0 & 13.9 & 14.0 & 14.1 & 13.1 \\
\hline $04 / 05$ & 12 & 14.1 & 14.2 & 14.2 & 14.0 & 13.4 \\
\hline $05 / 06$ & 13 & 14.2 & 14.3 & 14.2 & 14.2 & 13.4 \\
\hline $06 / 07$ & 14 & 10.0 & 10.0 & 10.0 & 10.0 & 9.7 \\
\hline $07 / 08$ & 15 & 14.2 & 14.2 & 14.2 & 14.3 & 13.9 \\
\hline $08 / 09$ & 16 & 14.2 & 14.3 & 14.2 & 14.3 & 14.1 \\
\hline $09 / 10$ & 17 & 14.3 & 14.3 & 14.3 & 14.3 & 14.2 \\
\hline $10 / 11$ & 18 & 14.3 & 14.3 & 14.3 & 14.3 & 14.2 \\
\hline $11 / 12$ & 19 & 10.0 & 10.0 & 10.0 & 10.0 & 10.0 \\
\hline $12 / 13$ & 20 & 14.3 & 14.3 & 14.3 & 14.3 & 14.2 \\
\hline
\end{tabular}

Northfield \& Rocky River $(\operatorname{Max}=16 \%)$

\begin{tabular}{|c|c|c|c|c|}
\hline $\begin{array}{l}\text { Base } \\
\text { Case }\end{array}$ & $\begin{array}{c}\text { Case } \\
1\end{array}$ & $\begin{array}{c}\text { Case } \\
3\end{array}$ & $\begin{array}{c}\text { Case } \\
2\end{array}$ & $\begin{array}{c}\text { Case } \\
4\end{array}$ \\
\hline 9.7 & 9.9 & 9.8 & 9.7 & 5.5 \\
\hline 9.9 & 11.4 & 10.6 & 9.9 & 6.4 \\
\hline 8.7 & 9.1 & 9.3 & 8.7 & 5.7 \\
\hline 11.5 & 12.2 & 12.1 & 11.5 & 8.3 \\
\hline 10.2 & 10.5 & 9.7 & 10.1 & 6.9 \\
\hline 11.9 & 12.8 & 12.2 & 12.5 & 9.3 \\
\hline 12.7 & 12.5 & 12.1 & 12.3 & 9.3 \\
\hline 11.1 & 11.5 & 10.8 & 11.1 & 8.8 \\
\hline 13.8 & 14.0 & 13.7 & 13.8 & 11.6 \\
\hline 12.4 & 12.2 & 11.6 & 12.2 & 10.5 \\
\hline 14.2 & 14.2 & 13.8 & 14.4 & 12.4 \\
\hline 14.5 & 14.7 & 14.1 & 14.3 & 12.5 \\
\hline 12.8 & 12.7 & 12.7 & 12.9 & 11.3 \\
\hline 15.1 & 15.0 & 15.2 & 15.3 & 13.7 \\
\hline 12.9 & 12.7 & 12.8 & 12.9 & 12.0 \\
\hline 15.0 & 15.2 & 14.9 & 15.2 & 14.2 \\
\hline 15.4 & 15.2 & 15.3 & 15.3 & 14.6 \\
\hline 13.2 & 13.2 & 13.0 & 13.2 & 12.9 \\
\hline 15.4 & 15.4 & 15.4 & 15.4 & 15.2 \\
\hline 13.2 & 13.2 & 13.2 & 13.2 & 13.0 \\
\hline
\end{tabular}


CAPACITY FACTORS FOR UNCOMMITTED PUMPED STORAGE UNITS

\begin{tabular}{|c|c|c|c|c|c|c|c|c|c|c|}
\hline $\begin{array}{r}\text { Study } \\
\text { Year } \\
\end{array}$ & $\begin{array}{c}\text { Year } \\
\text { No. }\end{array}$ & $\begin{array}{l}\text { Base } \\
\text { Case } \\
\text { Max. }\end{array}$ & $\begin{array}{c}\text { Base } \\
\text { Case } \\
\text { Actual } \\
\end{array}$ & $\begin{array}{c}\text { Case } 1 \\
\text { Max } \\
\end{array}$ & $\begin{array}{l}\text { Case } 1 \\
\text { Actual } \\
\end{array}$ & $\begin{array}{c}\text { Case } 3 \\
\operatorname{Max} \\
\end{array}$ & $\begin{array}{l}\text { Case } 3 \\
\text { Actual } \\
\end{array}$ & $\begin{array}{l}\text { Case } \\
2 \& 4 \\
\operatorname{Max} \\
\end{array}$ & $\begin{array}{l}\text { Case } 2 \\
\text { Actual } \\
\end{array}$ & $\begin{array}{l}\text { Case } 4 \\
\text { Actual } \\
\end{array}$ \\
\hline $1992-1993$ & 0 & & & & & & & & & \\
\hline $93 / 94$ & 1 & 0 & - & 17.8 & 6.1 & 17.8 & 4.8 & - & - & - \\
\hline $94 / 95$ & 2 & 0 & - & 17.8 & 6.7 & 17.8 & 5.9 & - & - & - \\
\hline $95 / 96$ & 3 & 0 & - & 17.8 & 7.6 & 17.8 & 6.6 & - & - & - \\
\hline $96 / 97$ & 4 & 19.7 & 11.9 & 18.2 & 7.9 & 17.8 & 7.4 & 17.8 & 7.9 & 5.2 \\
\hline $97 / 98$ & 5 & 19.7 & 13.0 & 18.2 & 9.9 & 17.8 & 7.1 & 17.8 & 9.4 & 5.6 \\
\hline $98 / 99$ & 6 & 19.7 & 12.7 & 18.2 & 9.3 & 17.8 & 7.9 & 17.8 & 9.9 & 5.6 \\
\hline $99 / 00$ & 7 & 19.7 & 13.4 & 18.2 & 9.3 & 17.8 & 8.3 & 17.8 & 9.6 & 6.0 \\
\hline $00 / 01$ & 8 & 19.7 & 13.9 & 18.4 & 10.5 & 18.2 & 9.8 & 17.8 & 11.7 & 7.5 \\
\hline $01 / 02$ & 9 & 19.7 & 14.5 & 18.4 & 12.3 & 18.2 & 11.4 & 17.8 & 12.8 & 8.8 \\
\hline $02 / 03$ & 10 & 19.7 & 16.6 & 18.4 & 13.3 & 18.2 & 11.9 & 17.8 & 13.4 & 10.7 \\
\hline $03 / 04$ & 11 & 19.7 & 15.5 & 18.4 & 13.1 & 18.2 & 11.6 & 17.8 & 13.8 & 10.6 \\
\hline $04 / 05$ & 12 & 19.7 & 15.3 & 18.6 & 13.6 & 18.4 & 12.1 & 17.8 & 13.5 & 11.1 \\
\hline $05 / 06$ & 13 & 19.7 & 14.1 & 18.6 & 13.4 & 18.6 & 12.4 & 17.8 & 15.8 & 12.3 \\
\hline $06 / 07$ & 14 & 19.7 & 17.5 & 18.6 & 14.7 & 18.6 & 14.4 & 17.8 & 16.0 & 12.6 \\
\hline $07 / 08$ & 15 & 19.7 & 17.8 & 18.6 & 14.5 & 18.6 & 13.7 & 17.8 & 15.6 & 13.3 \\
\hline $08 / 09$ & 16 & 19.7 & 17.1 & 18.6 & 15.8 & 18.6 & 14.3 & 17.8 & 15.9 & 13.3 \\
\hline $09 / 10$ & 17 & 19.7 & 18.2 & 18.6 & 16.3 & 18.6 & 15.4 & 17.8 & 16.3 & 14.0 \\
\hline $10 / 11$ & 18 & 19.7 & 15.9 & 18.8 & 16.2 & 18.6 & 13.6 & 17.8 & 17.1 & 15.3 \\
\hline $11 / 12$ & 19 & 19.7 & 18.9 & 18.8 & 17.8 & 18.6 & 15.8 & 17.8 & 17.2 & 16.0 \\
\hline $12 / 13$ & 20 & 19.7 & 18.8 & 18.8 & 17.3 & 18.6 & 17.3 & 17.8 & 17.1 & 16.3 \\
\hline
\end{tabular}


CAPACITY FACTORS FOR NUCLEAR AND COAL UNITS

\begin{tabular}{|c|c|c|c|c|c|c|c|c|c|c|}
\hline $\begin{array}{l}\text { Year } \\
\text { No. }\end{array}$ & $\begin{array}{c}\text { Base } \\
\text { Case } \\
\text { Nuclear } \\
\end{array}$ & $\begin{array}{l}\text { Base } \\
\text { Case } \\
\text { Coal } \\
\end{array}$ & $\begin{array}{l}\text { Case } 1 \\
\text { Nuclear } \\
\end{array}$ & $\begin{array}{c}\text { Case } 1 \\
\text { Coal } \\
\end{array}$ & $\begin{array}{l}\text { Case } 2 \\
\text { Nuclear } \\
\end{array}$ & $\begin{array}{c}\text { Case } 2 \\
\text { Coal } 1 \\
\end{array}$ & $\begin{array}{l}\text { Case } 3 \\
\text { Nuclear } \\
\end{array}$ & $\begin{array}{c}\text { Case }{ }^{3} \\
\text { Coal } \\
\end{array}$ & $\begin{array}{l}\text { Case } 4 \\
\text { Nuclear } \\
\end{array}$ & $\begin{array}{c}\text { Case } 4 \\
\text { Coal } \\
\end{array}$ \\
\hline \multicolumn{11}{|l|}{0} \\
\hline 1 & 74 & 75 & 74 & 76 & 74 & 75 & 74 & 82 & 74 & 71 \\
\hline 2 & 73 & 74 & 73 & 76 & 73 & 77 & 73 & 84 & 73 & 74 \\
\hline 3 & 74 & 73 & 74 & 74 & 74 & 75 & 74 & 81 & 74 & 73 \\
\hline 4 & 73 & 73 & 73 & 74 & 73 & 75 & 73 & 78 & 73 & 72 \\
\hline 5 & 72 & 73 & 72 & 74 & 72 & 75 & 72 & 79 & 72 & 73 \\
\hline 6 & 72 & 76 & 72 & 77 & 72 & 78 & 72 & 78 & 72 & 76 \\
\hline 7 & 73 & 74 & 73 & 75 & 73 & 75 & 71 & 77 & 73 & 74 \\
\hline 8 & 71 & 74 & 71 & 75 & 71 & 75 & 70 & 77 & 71 & 74 \\
\hline 9 & 71 & 72 & 71 & 74 & 71 & 74 & 70 & 76 & 71 & 74 \\
\hline 10 & 70 & 72 & 70 & 72 & 70 & 73 & 71 & 74 & 70 & 73 \\
\hline 11 & 72 & 73 & 71 & 74 & 72 & 75 & 72 & 76 & 72 & 76 \\
\hline 12 & 71 & 71 & 71 & 73 & 71 & 72 & 71 & 75 & 71 & 73 \\
\hline 13 & 71 & 69 & 71 & 70 & 71 & 71 & 71 & 74 & 71 & 71 \\
\hline 14 & 70 & 68 & 70 & 68 & 70 & 69 & 71 & 73 & 70 & 69 \\
\hline 15 & 72 & 68 & 72 & 69 & 72 & 70 & 72 & 73 & 72 & 70 \\
\hline 16 & 71 & 67 & 71 & 69 & 71 & 69 & 71 & 73 & 71 & 70 \\
\hline 17 & 71 & 65 & 72 & 66 & 72 & 66 & 71 & 70 & 71 & 67 \\
\hline 18 & 71 & 63 & 71 & 66 & 71 & 65 & 71 & 65 & 71 & 66 \\
\hline 19 & 71 & 62 & 72 & 63 & 71 & 62 & 72 & 64 & 71 & 63 \\
\hline 20 & 71 & 60 & 71 & 62 & 71 & 61 & 71 & 64 & 71 & 62 \\
\hline
\end{tabular}


APPENDIX 5 
COST SUMMARY FOR CVPS UPHS STUDY (ALL COSTS IN MILLIONS)

\begin{tabular}{|c|c|c|c|c|c|c|c|c|c|c|c|c|c|}
\hline \multirow[b]{2}{*}{$\begin{array}{r}\text { Study } \\
\text { Year } \\
\end{array}$} & \multirow[b]{2}{*}{$\begin{array}{c}\text { Year } \\
\text { No. } \\
\end{array}$} & \multicolumn{3}{|c|}{ Base Case } & \multicolumn{3}{|c|}{ Case 非 1} & \multicolumn{3}{|c|}{ Case 非 3} & \multicolumn{3}{|c|}{ Case 非2 } \\
\hline & & $\begin{array}{l}\text { P.W. } \\
\text { Capital } \\
\text { Rev. } \\
\text { Reg. } \\
\end{array}$ & $\begin{array}{l}\text { P.W. } \\
\text { Prod. } \\
\text { Rev. } \\
\text { Req. } \\
\end{array}$ & $\begin{array}{l}\text { P.W. } \\
\text { Total }\end{array}$ & $\begin{array}{c}\text { P.W. } \\
\text { Capital } \\
\text { Rev. } \\
\text { Req. } \\
\end{array}$ & $\begin{array}{l}\text { P.W. } \\
\text { Prod. } \\
\text { Rev. } \\
\text { Req. } \\
\end{array}$ & $\begin{array}{l}\text { P.W. } \\
\text { Tota1 }\end{array}$ & $\begin{array}{c}\text { P.W. } \\
\text { Capital } \\
\text { Rev. } \\
\text { Reg. } \\
\end{array}$ & $\begin{array}{l}\text { P.W. } \\
\text { Prod. } \\
\text { Rev. } \\
\text { Req. }\end{array}$ & $\begin{array}{l}\text { P.W. } \\
\text { Tota1 }\end{array}$ & $\begin{array}{c}\text { P.W. } \\
\text { Capital } \\
\text { Rev. } \\
\text { Req. } \\
\end{array}$ & $\begin{array}{l}\text { P.W. } \\
\text { Prod. } \\
\text { Rev. } \\
\text { Req. } \\
\end{array}$ & $\begin{array}{l}\text { P.W. } \\
\text { Tota1 } \\
\end{array}$ \\
\hline $1992 / 93$ & 0 & & & & & & & & & & & & \\
\hline $93 / 94$ & 1 & 681 & 10855 & 11536 & 681 & 10827 & 11508 & 0 & 11521 & 11521 & 681 & 10855 & 11536 \\
\hline $94 / 95$ & 2 & 923 & 10620 & 11543 & 923 & 10545 & 11468 & 0 & 11683 & 11683 & 923 & 10620 & 11543 \\
\hline $95 / 96$ & 3 & 1121 & 10182 & 11303 & 1121 & 10125 & 11246 & 308 & 11226 & 11534 & 1121 & 10182 & 11303 \\
\hline $96 / 97$ & 4 & 1330 & 9942 & 11272 & 1330 & 9885 & 11215 & 564 & 11029 & 11593 & 1281 & 9917 & 11198 \\
\hline $97 / 98$ & 5 & 1815 & 8985 & 10800 & 1815 & 8945 & 10760 & 1140 & 9988 & 11128 & 1772 & 8978 & 10750 \\
\hline $98 / 99$ & 6 & 1599 & 9013 & 10612 & 1599 & 9004 & 10603 & 1270 & 9768 & 11038 & 1560 & 8971 & 10531 \\
\hline $99 / 00$ & 7 & 1661 & 8741 & 10402 & 1661 & 8759 & 10420 & 1701 & 8963 & 10664 & 1627 & 8760 & 10387 \\
\hline $00 / 01$ & 8 & 2057 & 8175 & 10232 & 2057 & 8152 & 10209 & 2092 & 8311 & 10403 & 1987 & 8143 & 10130 \\
\hline $01 / 02$ & 9 & 2339 & 7602 & 9941 & 2339 & 7547 & 9886 & 2370 & 7635 & 10005 & 2277 & 7564 & 9841 \\
\hline $02 / 03$ & 10 & 2561 & 7063 & 9624 & 2561 & 7047 & 9608 & 2305 & 7494 & 9799 & 2507 & 7040 & 9547 \\
\hline $03 / 04$ & 11 & 2256 & 7003 & 9259 & 2256 & 6893 & 9149 & 2030 & 7452 & 9482 & 2208 & 6970 & 9178 \\
\hline $04 / 05$ & 12 & 2474 & 6654 & 9128 & 2474 & 6577 & 9051 & 2275 & 6963 & 9238 & 2399 & 6653 & 9052 \\
\hline $05 / 06$ & 13 & 2632 & 6151 & 8783 & 2611 & 6102 & 8713 & 2467 & 6458 & 8925 & 2544 & 6109 & 8653 \\
\hline $06 / 07$ & 14 & 2729 & 5814 & 8543 & 2710 & 5797 & 8507 & 2583 & 6040 & 8623 & 2651 & 5799 & 8450 \\
\hline $07 / 08$ & 15 & 2416 & 5783 & 8199 & 2387 & 5770 & 8157 & 2288 & 6134 & 8422 & 2348 & 5760 & 8108 \\
\hline $08 / 09$ & 16 & 2506 & 5522 & 8028 & 2474 & 5429 & 7903 & 2387 & 5770 & 8157 & 2440 & 5469 & 7909 \\
\hline $09 / 10$ & 17 & 2561 & 5138 & 7699 & 2533 & 5078 & 7611 & 2462 & 5399 & 7861 & 2508 & 5114 & 7622 \\
\hline $10 / 11$ & 18 & 2622 & 4914 & 7536 & 2592 & 4818 & 7410 & 2667 & 5050 & 7717 & 2562 & 4904 & 7466 \\
\hline $11 / 12$ & 19 & 2629 & 4568 & 7197 & 2603 & 4502 & 7105 & 2488 & 4964 & 7452 & 2577 & 4567 & 7144 \\
\hline $12 / 13$ & 20 & 2620 & 4409 & 7029 & 2597 & 4321 & 6918 & 2495 & 4716 & 7211 & 2579 & 4401 & 6980 \\
\hline Tota1 & $1-20$ & 41532 & 147134 & 188666 & 41323 & 146123 & 187446 & 35893 & 156564 & 192457 & 40552 & 146776 & 187328 \\
\hline
\end{tabular}




\begin{tabular}{|c|c|c|c|}
\hline \multirow[b]{2}{*}{$\begin{array}{l}\text { Year } \\
\text { No. } \\
\end{array}$} & \multicolumn{3}{|c|}{$\begin{array}{c}\text { COST SUMMARY (CONTINUED) } \\
\text { Case } \# 4\end{array}$} \\
\hline & $\begin{array}{c}\text { P.W. } \\
\text { Capital } \\
\text { Rev. } \\
\text { Req. } \\
\end{array}$ & $\begin{array}{l}\text { P.W. } \\
\text { Prod. } \\
\text { Rev. } \\
\text { Req. }\end{array}$ & $\begin{array}{l}\text { P.W. } \\
\text { Total } \\
\end{array}$ \\
\hline 0 & & & \\
\hline 1 & 681 & 12089 & 12770 \\
\hline 2 & 923 & 11782 & 12705 \\
\hline 3 & 1121 & 11255 & 12376 \\
\hline 4 & 1281 & 10982 & 12263 \\
\hline 5 & 1772 & 9985 & 11757 \\
\hline 6 & 1560 & 9997 & 11557 \\
\hline 7 & 1627 & 9696 & 11323 \\
\hline 8 & 1987 & 9022 & 11109 \\
\hline 9 & 2277 & 8356 & 10633 \\
\hline 10 & 2507 & 7785 & 10292 \\
\hline 11 & 2208 & 7670 & 9878 \\
\hline 12 & 2399 & 7302 & 9701 \\
\hline 13 & 2544 & 6746 & 9290 \\
\hline 14 & 2651 & 6388 & 9039 \\
\hline 15 & 2342 & 6321 & 8663 \\
\hline 16 & 2440 & 5980 & 8420 \\
\hline 17 & 2503 & 5601 & 8104 \\
\hline 18 & 2557 & 5321 & 7878 \\
\hline 19 & 2572 & 4966 & 7538 \\
\hline 20 & 2580 & 4770 & 7350 \\
\hline $1-20$ & 40532 & 162014 & 202546 \\
\hline
\end{tabular}


APPENDIX 6

A-33 

OIL USEAGE - BASE CASE

(Millions of Barrels)

\begin{tabular}{|c|c|c|c|c|c|c|c|}
\hline $\begin{array}{l}\text { Year } \\
\text { No. }\end{array}$ & 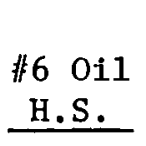 & $\begin{array}{l}\text { \#6 Oi1 } \\
\text { Low S. }\end{array}$ & $\begin{array}{l}\# 6 \text { oil } \\
\text { Med. S. }\end{array}$ & $\begin{array}{l}\text { Total } \\
\# 6 \text { Oil } \\
\end{array}$ & \#2 Oi1 & $\begin{array}{l}\text { Jet } \\
\text { Fue1 } \\
\end{array}$ & $\begin{array}{r}\text { Total } \\
\text { \#2 Oil } \\
+ \text { Jet } \\
\end{array}$ \\
\hline \multicolumn{8}{|l|}{0} \\
\hline 1 & 22.6 & 16.3 & 13.9 & 52.8 & 1.8 & .7 & 2.5 \\
\hline 2 & 22.8 & 15.9 & 13.9 & 52.6 & 1.8 & .6 & 2.4 \\
\hline 3 & 21.7 & 15.0 & 13.8 & 50.5 & 1.6 & .5 & 2.1 \\
\hline 4 & 21.8 & 14.9 & 13.3 & 50.0 & 1.5 & .5 & 2.0 \\
\hline 5 & 19.8 & 12.5 & 12.2 & 44.5 & .8 & .1 & .9 \\
\hline 6 & 20.4 & 13.4 & 13.3 & 47.1 & 1.4 & .4 & 1.8 \\
\hline 7 & 20.4 & 13.4 & 12.8 & 46.6 & 1.1 & .2 & 1.3 \\
\hline 8 & 19.5 & 12.2 & 12.0 & 43.7 & .9 & .2 & 1.1 \\
\hline 9 & 18.0 & 11.2 & 11.4 & 40.6 & .7 & .1 & .8 \\
\hline 10 & 16.9 & 9.7 & 10.7 & 37.3 & .4 & - & .4 \\
\hline 11 & 17.5 & 10.5 & 11.5 & 39.5 & .6 & .1 & .7 \\
\hline 12 & 17.5 & 9.8 & 11.2 & 38.5 & .6 & .1 & .7 \\
\hline 13 & 15.7 & 9.2 & 10.2 & 35.1 & .4 & - & .4 \\
\hline 14 & 15.1 & 8.2 & 10.1 & 33.4 & .3 & - & .3 \\
\hline 15 & 16.0 & 9.2 & 10.7 & 35.9 & .6 & - & .6 \\
\hline 16 & 15.7 & 9.2 & 10.0 & 34.9 & .6 & - & .6 \\
\hline 17 & 14.7 & 8.1 & 9.6 & 32.4 & .4 & - & .4 \\
\hline 18 & 14.4 & 7.7 & 9.5 & 31.6 & .3 & - & .3 \\
\hline 19 & 12.9 & 6.6 & 9.0 & 28.5 & .2 & - & .2 \\
\hline 20 & 13.1 & 6.9 & 8.5 & 28.5 & .2 & - & .2 \\
\hline
\end{tabular}


OIL USAGE - CASE 非 1

(Millions of Barrels)

\begin{tabular}{|c|c|c|c|c|c|c|c|}
\hline $\begin{array}{l}\text { Year } \\
\text { No. }\end{array}$ & $\begin{array}{l}\# 6 \quad 011 \\
\text { H.S. } \\
\end{array}$ & $\begin{array}{c}\text { \#6 } 011 \\
\text { L.S. } \\
\end{array}$ & $\begin{array}{l}\text { \#6 } 011 \\
\text { M.S. } \\
\end{array}$ & $\begin{array}{l}\text { Total } \\
\# 6 \text { Oil } \\
\end{array}$ & \#2 011 & $\begin{array}{l}\text { Jet } \\
\text { Fuel }\end{array}$ & $\begin{array}{l}\text { Tota } 1 \\
\text { \#1 } 2 \text { 0il } \\
+ \text { Jet } \\
\end{array}$ \\
\hline 1 & 22.7 & 15.7 & 14.1 & 52.5 & 1.7 & .6 & 2.3 \\
\hline 2 & 23.0 & 14.7 & 14.0 & 51.7 & 1.6 & .6 & 2.2 \\
\hline 3 & 21.8 & 14.7 & 13.4 & 49.9 & 1.4 & .5 & 1.9 \\
\hline 4 & 21.5 & 14.3 & 13.3 & 49.1 & 1.5 & .5 & 2.0 \\
\hline 5 & 19.3 & 11.7 & 12.6 & 43.6 & .9 & .3 & 1.2 \\
\hline 6 & 20.8 & 13.0 & 12.7 & 46.5 & 1.3 & .6 & 1.9 \\
\hline 7 & 20.4 & 13.3 & 12.7 & 46.4 & 1.2 & .4 & 1.6 \\
\hline 8 & 19.9 & 11.4 & 11.8 & 43.1 & .9 & .2 & 1.1 \\
\hline 9 & 17.8 & 9.9 & 11.8 & 39.5 & .6 & .2 & .8 \\
\hline 10 & 17.3 & 8.8 & 10.6 & 36.7 & .5 & .1 & .6 \\
\hline 11 & 17.9 & 9.7 & 11.2 & 38.8 & .7 & .2 & .9 \\
\hline 12 & 16.7 & 9.3 & 10.7 & 36.7 & .6 & .1 & .7 \\
\hline 13 & 15.3 & 8.2 & 10.3 & 33.8 & .4 & .1 & .5 \\
\hline 14 & 15.4 & 7.6 & 9.9 & 32.9 & .4 & - & .4 \\
\hline 15 & 16.2 & 9.1 & 10.2 & 35.5 & .4 & .1 & .5 \\
\hline 16 & 15.6 & 7.6 & 9.8 & 33.0 & .3 & .1 & .4 \\
\hline 17 & 14.7 & 6.9 & 9.2 & 30.8 & .3 & - & .3 \\
\hline 18 & 13.7 & 6.5 & 9.2 & 29.4 & .1 & - & .1 \\
\hline 19 & 12.9 & 5.7 & 8.6 & 27.2 & .1 & - & .1 \\
\hline 20 & 12.4 & 5.7 & 8.4 & 26.5 & .1 & - & .1 \\
\hline
\end{tabular}


OIL USAGE - CASE \#2

(Millions of Barrels)

\begin{tabular}{|c|c|c|c|c|c|c|c|}
\hline $\begin{array}{l}\text { Year } \\
\text { No. } \\
\end{array}$ & $\begin{array}{l}\# 6 \quad 011 \\
\text { H.S. } \\
\end{array}$ & $\begin{array}{l}\# 6 \text { oil } \\
\text { L.S. } \\
\end{array}$ & $\begin{array}{l}\text { \#6 } 011 \\
\text { M.S. } \\
\end{array}$ & $\begin{array}{l}\text { Total } \\
\text { \#1 } 6 \text { 0i1 }\end{array}$ & 非 0 Oil & $\begin{array}{l}\text { Jet } \\
\text { Fuel } \\
\end{array}$ & $\begin{array}{l}\text { Total } \\
\text { \#2 } 211 \\
+\quad \mathrm{Jet} \\
\end{array}$ \\
\hline 1 & 22.6 & 16.3 & 13.9 & 52.8 & 1.8 & .7 & 2.5 \\
\hline 2 & 22.8 & 15.9 & 13.9 & 52.6 & 1.8 & .6 & 2.4 \\
\hline 3 & 21.7 & 15.0 & 13.8 & 50.5 & 1.6 & .5 & 2.1 \\
\hline 4 & 21.6 & 14.6 & 13.2 & 49.4 & 1.5 & .5 & 2.0 \\
\hline 5 & 19.2 & 12.2 & 12.5 & 43.9 & 1.0 & .2 & 1.2 \\
\hline 6 & 20.5 & 12.9 & 12.9 & 46.3 & 1.2 & .5 & 1.7 \\
\hline 7 & 20.7 & 13.2 & 12.7 & 46.6 & 1.1 & .4 & 1.5 \\
\hline 8 & 19.1 & 11.8 & 12.4 & 43.3 & .8 & .2 & 1.0 \\
\hline 9 & 18.2 & 10.5 & 11.3 & 40.0 & .7 & .1 & .8 \\
\hline 10 & 17.0 & 9.1 & 10.8 & 36.9 & .5 & .1 & .6 \\
\hline 11 & 17.7 & 10.0 & 11.1 & 38.8 & .6 & .1 & .7 \\
\hline 12 & 17.0 & 10.2 & 11.2 & 38.4 & .6 & .1 & .7 \\
\hline 13 & 15.7 & 8.5 & 10.1 & 34.3 & .3 & - & .3 \\
\hline 14 & 15.1 & 7.9 & 10.1 & 33.1 & .2 & - & .2 \\
\hline 15 & 16.1 & 9.0 & 10.4 & 35.5 & .5 & - & .5 \\
\hline 16 & 15.1 & 8.9 & 10.0 & 34.0 & .4 & - & .4 \\
\hline 17 & 14.5 & 7.8 & 9.5 & 31.8 & .3 & - & .3 \\
\hline 18 & 14.1 & 7.6 & 9.7 & 31.4 & .3 & - & .3 \\
\hline 19 & 13.1 & 6.6 & 8.7 & 28.4 & .2 & - & .2 \\
\hline 20 & 12.9 & 7.0 & 8.5 & 28.4 & .2 & - & .2 \\
\hline
\end{tabular}


OIL USAGE - CASE 非

(Millions of Barrels)

\begin{tabular}{|c|c|c|c|c|c|c|c|}
\hline $\begin{array}{l}\text { Year } \\
\text { No. } \\
\end{array}$ & $\begin{array}{c}\text { 非6 } 011 \\
\text { H.S. } \\
\end{array}$ & $\begin{array}{c}\text { \#6 } 011 \\
\text { L.S. } \\
\end{array}$ & $\begin{array}{c}\text { \#6 } 011 \\
\text { M.S. } \\
\end{array}$ & $\begin{array}{l}\text { Total } \\
\text { 非 } 6 \text { Oi1 } \\
\end{array}$ & 非 & $\begin{array}{l}\text { Jet } \\
\text { Fuel } \\
\end{array}$ & $\begin{array}{l}\text { Total } \\
\text { \#2 } 011 \\
+ \text { Jet } \\
\end{array}$ \\
\hline \multicolumn{8}{|l|}{0} \\
\hline 1 & 25.4 & 19.6 & 15.7 & 60.7 & 2.8 & 1.3 & 4.1 \\
\hline 2 & 26.9 & 21.5 & 16.4 & 64.8 & 3.5 & 1.7 & 5.2 \\
\hline 3 & 26.2 & 20.6 & 16.3 & 63.1 & 3.3 & 1.6 & 4.9 \\
\hline 4 & 26.4 & 20.9 & 16.2 & 63.5 & 3.3 & 1.7 & 5.0 \\
\hline 5 & 24.3 & 18.5 & 15.0 & 57.8 & 2.4 & 1.1 & 3.5 \\
\hline 6 & 24.9 & 17.8 & 15.0 & 57.7 & 2.5 & 1.1 & 3.6 \\
\hline 7 & 22.8 & 15.9 & 14.7 & 53.4 & 1.9 & .7 & 2.6 \\
\hline 8 & 21.7 & 14.4 & 13.5 & 49.6 & 1.5 & .5 & 2.0 \\
\hline 9 & 20.2 & 12.7 & 12.7 & 45.6 & 1.0 & .3 & 1.3 \\
\hline 10 & 19.8 & 13.0 & 12.7 & 45.5 & 1.2 & .4 & 1.6 \\
\hline 11 & 20.7 & 14.2 & 13.1 & 48.0 & 1.4 & .4 & 1.8 \\
\hline 12 & 19.9 & 12.8 & 12.4 & 45.1 & 1.1 & .3 & 1.4 \\
\hline 13 & 18.3 & 11.1 & 12.3 & 41.7 & .8 & .2 & 1.0 \\
\hline 14 & 17.8 & 10.0 & 11.3 & 39.1 & .6 & .1 & .7 \\
\hline 15 & 19.1 & 11.9 & 12.3 & 43.3 & 1.2 & .2 & 1.4 \\
\hline 16 & 18.0 & 11.4 & 11.5 & 40.9 & 1.0 & .2 & 1.2 \\
\hline 17 & 17.0 & 10.2 & 11.4 & 38.6 & .8 & .1 & .9 \\
\hline 18 & 15.9 & 8.5 & 10.6 & 35.0 & .5 & - & .5 \\
\hline 19 & 16.2 & 8.9 & 10.4 & 35.5 & .7 & - & .7 \\
\hline 20 & 15.2 & 8.3 & 10.2 & 33.7 & .6 & - & .6 \\
\hline
\end{tabular}


OIL USAGE - CASE \# 4

(Millions of Barrels)

\begin{tabular}{|c|c|c|c|c|c|c|c|}
\hline $\begin{array}{l}\text { Year } \\
\text { No. } \\
\end{array}$ & $\begin{array}{c}\# 6 \text { O Oi1 } \\
\text { H.S. } \\
\end{array}$ & $\begin{array}{c}\text { \#16 Oil } \\
\text { L.S. } \\
\end{array}$ & $\begin{array}{c}\text { \#6 Oil } \\
\text { M.S. } \\
\end{array}$ & $\begin{array}{l}\text { Total } \\
\# 6 \text { 0i1 }\end{array}$ & \#2 011 & $\begin{array}{l}\text { Jet } \\
\text { Fuel } \\
\end{array}$ & $\begin{array}{l}\text { Total } \\
\text { \#2 Oil } \\
+ \text { Jet } \\
\end{array}$ \\
\hline 1 & 31.1 & 22.1 & 16.3 & 69.5 & 2.1 & .8 & 2.9 \\
\hline 2 & 31.0 & 21.5 & 16.1 & 68.6 & 2.2 & .8 & 3.0 \\
\hline 3 & 29.9 & 20.4 & 15.9 & 66.2 & 1.9 & .6 & 2.5 \\
\hline 4 & 29.9 & 20.1 & 15.4 & 65.4 & 1.9 & .7 & 2.6 \\
\hline 5 & 27.1 & 17.8 & 14.7 & 59.6 & 1.3 & .3 & 1.6 \\
\hline 6 & 28.5 & 18.6 & 15.3 & 62.4 & 1.7 & .6 & 2.3 \\
\hline 7 & 28.5 & 18.6 & 14.8 & 61.9 & 1.6 & .5 & 2.1 \\
\hline 8 & 26.9 & 17.1 & 14.4 & 58.4 & 1.2 & .3 & 1.5 \\
\hline 9 & 25.5 & 15.3 & 13.4 & 54.2 & .9 & .2 & 1.1 \\
\hline 10 & 23.9 & 13.7 & 13.1 & 50.7 & .8 & .2 & 1.0 \\
\hline 11 & 25.0 & 14.2 & 13.3 & 52.5 & .9 & .2 & 1.1 \\
\hline 12 & 23.9 & 14.6 & 12.7 & 51.2 & .9 & .2 & 1.1 \\
\hline 13 & 22.4 & 12.7 & 12.3 & 47.4 & .6 & .1 & .7 \\
\hline 14 & 22.1 & 11.9 & 12.0 & 46.0 & .5 & .1 & .6 \\
\hline 15 & 22.7 & 13.1 & 12.3 & 48.1 & .7 & .1 & .8 \\
\hline 16 & 21.7 & 12.6 & 11.6 & 45.9 & .6 & .1 & .7 \\
\hline 17 & 20.7 & 11.4 & 11.4 & 43.5 & .5 & - & .5 \\
\hline 18 & 20.3 & 10.8 & 11.1 & 42.2 & .4 & - & .4 \\
\hline 19 & 19.0 & 10.0 & 10.4 & 39.4 & .3 & - & .3 \\
\hline 20 & 18.4 & 10.1 & 10.1 & 38.6 & .4 & - & .4 \\
\hline
\end{tabular}


PNL -4248

UC-94e

\section{DISTRIBUTION}

No. of

Copies

OFFSITE

Acres American, Inc.

Attn: M.J. Hobson

The Clark Building

Suite 329

Columbia, MD 21044

Acres American, Inc.

Attn: D. Willett

Liberty Bank Building

Main at Court

Buffalo, NY 14202

- Commonwealth Edison Co.

Attn: T.J. Maiman

Sta. Mech. Engr. Dept. Mgr.

36 FN West

PO Box 767

Chicago, IL 60690

27 DOE Technical Information Center

5 US Department of Energy

Attn: R. Shivers

Office of Energy Systems Res.

Forrestal Building (Room 1G-080)

1000 Independence Ave., S.W.

Washington, DC 20585

US Department of Energy

Attn: J.H. Swisher

Office of Energy Systems Res.

Forrestal Building (Room 1G-080)

1000 Independence Ave., S.W.

Washington, DC 20585
No of

Copies

US Department of Energy

Attn: A.A. Churm

Chicago Patent Group

Chicago Operations Office

9800 South Cass Avenue

Argonne, IL 60439

5 US Department of Energy

Attn: I. Gyuk

Office of Energy Systems Res.

Forrestal Building (Room 1G-080)

1000 Independence Ave., S.W.

Washington, DC 20585

US Department of Energy

Attn: J. Mathur

Division of Environmental

Safety and Engineering

MS-E201, Germantown

Washington, DC 20545

US Department of Energy

Attn: R.A. Dunlop

Division of Electric Energy Sys.

12 \& Pennsylvania

Washington, DC 20585

Harza Engineering Company

Attn: A.H. Barber

Director of Marketing

150 S. Wacker Drive

Chicago, IL 60606

2 Lawrence Livermore Laboratory

Attn: Tech. Info. Dept., L-3

University of California

PO Box 808

Livermore, CA 94550 
No of

Copies

Marchwood Engineering Labs

Attn: I. Glendenning

Head of Long-Term Studies

Southampton, England

National Science Foundation

Division of Advanced Energy

Research and Technology

Room 1140

1800 G Street, NW

Washington, DC 20550

Northern Research \& Eng. Corp. Attn: Jerry 0. Melconian

39 0lympia Avenue

Wobrun, MA 01801

Potomac Electric Power Co

Attn: P E. Schaub

1900 Pennsylvania Avnue

Washington, DC 20006

$\mathrm{Re} / \mathrm{Spec}$ Inc.

Attn: A.F. Fossum

PO Box 725

Rapid City, SD 57701

Sandia Laboratories

Attn: H.M. Dodd

Organization 5743

A1buquerque, NM 87115

Sandia Laboratories

Attn: R.0. Woods

Organization 4715

Albuquerque, NM 87115

Sandia Laboratories

Attn: William G. Wilson

PO Box 969

Organization 8453

Livermore, CA 94550
No. of

Copies

Soyland Power Cooperative, Inc. Attn: Royal B. Newman P0 Box A1606

Decabur, IL 62525

Tennessee Valley Authority

Energy Research Section

1360 Commerce Union Bank B1dg

Chattanooga, TN 37401

Tennessee Valley Authority

Attn: Gerald Phillips

1150 Chestnut, Tower 2

Chattanooga, TN 37401

TRW Energy Systems Group

Attn: E. Berman

Technical Library

7600 Colshire Drive

McLean, VA 22101

Union Electric Co.

Attn: E.M. Mabuce

Manager - Applied Research

Corporate Planning Dept.

PO Box 149

St. Louis, MO 63166

University of California

Attn: T.L. Brekke

Department of Civil Engineering

1847 Yosemite Road

Berkeley, CA 94707

University of Massachusetts

Attn: 0.C. Farquhar

Dept. of Geology \& Geography

Morrill Science Center

Amherst, MA 01003 
ONSITE

DOE Richland Operations Office

H. E. Ransom/D.R. Segna

Pacific Northwest Laboratory

T. J. Doherty (20)

L. D. Kannberg (10)

Technical Information (5)

Publishing Coordination (2) 
